\title{
EXPERIMENTAL STUDIES ON THE MEDICAL TREATMENT OF SUPPURATIVE MENINGITIS
}

\author{
By \\ J. KIKUCHI \\ From the Department of Otorhinolaryngology, Iwate medical college, Morioka \\ (Director: Prof. I. Konno)
}

The experimental study was done on the medical treatment of suppurative meningitis using sulfa drugs such as domian, thiazine and supronal, and antibiotics such as penicillin $(P)$, streptomycin (SM), chlortetracyclin (CTC), oxytetracyclin (OTC), tetracyclin (TC), chloramphenicol (CM) and erythromycin (EM). The drugs were given to normal and diseased rabbits by oral route, intravenous or intramuscular injection.

I. The dispersion into the cerebrospinal fluid.

In the sulfa-drugs, the best dispersion was seen with domian, next with supronal and then with thiazine. When the drugs were given intravenously, the dispersion into the spinal fluid and also the elimination from the spinal fluid were remarkably faster than that of oral administration. However, the concentration in the spinal fluid did not show remarkable difference when the drugs were given "intravenously or orally, suggesting that the initial dose to be given intravenously in urgent cases and followed by oral maintenauce doses.

In the antibiotics, the best dispersion was shown by CM and TC and then OTC, CTC, SM, EM and $P$ in order. In the rabbits with meningitis, the effective concentration of $C M$ and $T C$ in the cerebrospinal fluid was maintained for 6 hours after the injection but the effective concentration of the other antibiotics was maintained for 3 hours after the injection in most of the cases.

Though CM, TC and OTC were effective in the treatment of meningitis other antibiotics were less effective in the treatment because of lower concentration, short duration of effective concentration and uncertain dispersion.

II. Meningeal irritation

Sulfa drugs were strongly irritative and inappropriate for the intrathecal use. Among the antibiotics, P, TC and OTC were slightly irritative, CTC and SM were moderately irritative and $\mathrm{CM}$ and EM were most irritative. Among these antibiotics, OTCWas least irritative. $\mathrm{P}, \mathrm{TC}$ and OTC were thought to be most appropriate for the intrathecal use.

III. Elimination of drugs from the cerebrospinal cavity.

In the normal rabbits, $\mathrm{P}, \mathrm{OTC}, \mathrm{TC}$ and $\mathrm{CM}$ in the cerebrospinal fluid were eliminated quickly. and disappeared in $6 \sim 7$ hours from the spinal cavity. SM, CTC and EM were eliminated slowly and considerable amount of the antibiotics remained in the fluid even 24 hours after the injection.

In the rabbits with meningitis, the elimination of the drugs from the cerebrospinal cavity was retarded, effective coricentration being kept for $18 \sim 24$ hours.

IV. Drugs to promote the dispersion of the antibiotics into the cerebrospinal fluid.

Hyaluronidase, methobromine, amid of nicotinic acid and immidarin were given togather with CM, EM and $P$, and the change in dispersion of these drugs in the cerebrospinal fluid was studied using the normal rabbits. These drugs except immidarin increased the dispersion of the antibiotics into the cerebrospinal fluid, particularly that of EM. and P. 


\title{
化膿性揈膜炎の薬物療法に関する基礎的研究
}

\author{
第 1 篇 スルファミン剂ならびに抗生物質の能道液内移行 \\ に関する実験的研究
}

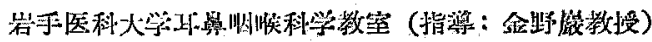

$$
\text { 菊莎 準 }
$$

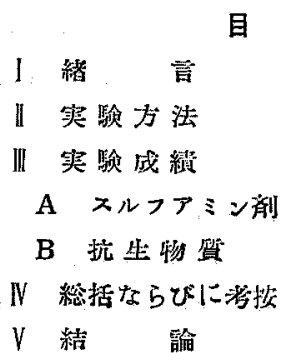

I. 緒言

現在化膿性佮道膜炎の治療に用いられる蒋物はスルフア ミン剂と抗生物質であり，その投与法には全身的投与法 と䯣液内注射法とがある・全身的以薬物投与を行う場 合，最も基礎的な問題は使用する萖物が䯣液内に移行し 得るか否かということである。

スルフアミン剂については経口投与で䯈夜内に移行す ることは知られているが、その主なる研究は Jauerneck u. Gueffroy (1937) のプロントジル，プロントジルーS, スルフアニールアマイド関するもの, Marschall et. al. (1937): Allot (1939) のスルフアニールアマイドに 関与るもの, Bliss \& Long (1939) のスルフアニール アマイド，プロントジルーS，スルフアビリジンに開寸 るもの, Hobson \& Mac Quaide (1938); Chinn \& Bellows (1940) のスルフアピリジンに閣するもの， Hamburger et. al. (1942) のスルフアビラジンに関す るもの, Strauss et. al. (1941); Cutting \& Sultan (1943) のスルフアニールアマイド，スルフアピりジン， スルファテアゾールに閏するもの，Murphy et. al. (1943) のスルフアメチールダイアジン（スルフアメラ ジン)に関するもの, Sadusk et. al. (1940); Horwitz \& Perroin (1944) のスルフアチアブールに関するも の, Appelbaum \& Nelson (1944) のスルフアダイア ジンに閣するものがあり，本邦では鍵和田のスルフアダ イアジンに関するるの，真下゙のスルフアニールアマイ ド,スルフアチアゾール，スルフアダイアジンに関する
研究，飯挥のスルフアダイアジン，スルフアメシジン， スルフアチアゾールに関するるのである・これらの成眇 についてみるとスルフアーニルア、イドが最よく路液 内移行するが，この誘導体であるプロントジルーS 踊腹内に移行し難い。またスルフアミンのアミ，基の水 㨞が5原子複素環式化合物で置換されたスルフアチアタ

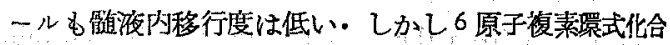
物で犆換されたスルフアピリジン，スルフアダイアシ ン，スルフアメラジンは相当よく髓液内に移行してい る・このスルフアミン剂の䯣液内移行について，真下は 血墏中アルブミンと結合していない遊離の状態にあるも

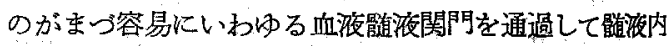
に移行すると考光，血液䯣液閿門の機能は一見撰把的で

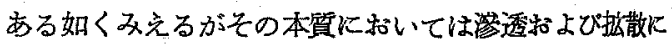
よるものであると言い，飯塚はスルフアミン剂の血腋噵

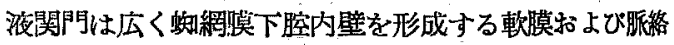
滕の全毛細血管にあることを指摘している。

抗生物質のうら，ペニシリン，ストレプトマイシンに

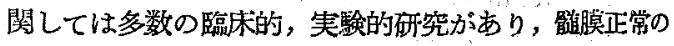
場合には㱠んど移行せず，䯣裳炎の時にはある程度移行 するといら発表が多いしいか Boger のようにぺ=シ リン 10 万笚位を 3 時間毎に健康者に筋注してその $80 \%$ に移行を認めたものがあり，また萩間によれば骮液内兄 のストレプトマイシンの移行は比較的よく，能注のみで る能迹液中に有效濃度を保持しその治潦效果を期街し得る と述べている。

クロルテトラサイリリン(ォーレオマイシン)に関し ては，内服の場合 Redriqez, Brained，飯尾は䯣液内移 行を認めていないが，Furstenbergによれば喵液中の 濃度は血中濃度の約 50\%であると述べて招り，Leppar は9 例中 6 例に霣液们移行を諗めている・静脈注射の場

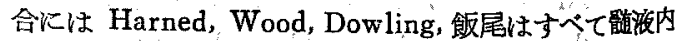
移行を認めている・しかして A. Walker \& F.D. Bosanquet によれば内服, 静注ともオーレオマイシンは 


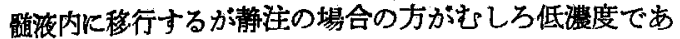
ると述べてる。

オキシテトラサイタリン(テラマイシン)に関しては， Wood の静注による成績で 5 例中 2 例に 移行を諗め ている。

テトラサイタリン（アクロマイシン）飞関しては，内 服の場合白羽教授は韧液内稳行を認めているが，Pulaski は血中浱度を 6.0〜 5.4r/cc には僅かに痕跡を証明与るに過ぎなからたと報告してい る・静注の場合には Wood は 5 例中 5 例に移行を認め

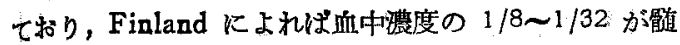
液中心証明されると述べいる。

クロシムフンニュル（クロロマイセチン）については 豊田の成樍があり，静注，皮下注射でかなりの䯘液内移 行方譟明されている。

エリスロマイシン（アイロタイシン）に関して，東鄉 は有效洤度の鲔液内移行は証明しないと述へ，Grigsby， 飯尾も同様の成續であるが，Heilman は9例中 4 例化 稳行を認め, Anderson は全例に移行を認めている。

以上のように抗生物質の疑液内移行に関しては一定し

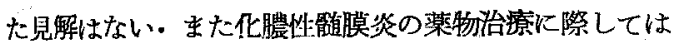
最も移行度の高いものを第1に使用す心゙きであると考え

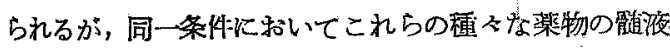
内移行度の比較検討はざれていない，この点を明らかて するため，スルフアミン郕としてドミアン (6-Sulfanilamide 2-4 Dimethylpyrimisine), サイアジン (Sulfaisooxyasol) ならびにスプロナール (Sulfamerazine $50 \%+$ Sulfathioureasalt of Homosulfamine 50\%), 抗生物質としてペニシリン，ストレプトマイシン，クロ ルテトシタイタソン（オーレオマイシン）、キシデ ラサイクンン(テタマイシン)，テトシサイタリン(ア クロマイシン), クロシムフェニコル（クロロマイせ ๖), エリスロマイシン（アイロタイシン）につて梁 䖻的に実験し比較検討した。

\section{II. 実験方法}

実駼動物には体重 $2 \mathrm{~kg}$ 前後の健康家鬼ならびに実験

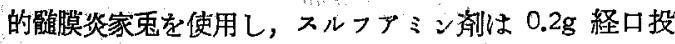
与の場合，5\% 溶液 $1 \mathrm{cc}$ の耳静脈注射の埸合，抗生物 質は $10 \mathrm{mg} / \mathrm{kg}$ を笳注した場合ならびに耳静脈汇注射し た場合火ついて，一定時間每に耳静脈より $0.6 \mathrm{cc}$ 採血，

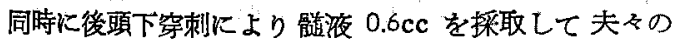

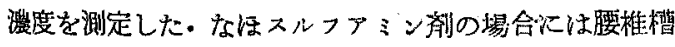
からも能液を採取した。
湘定方法はスルフアミン赤は Werner 氏法により， 抗生物質は枯草菌 MD-15を用いた窝村氏の薄首かッ ブ法である・

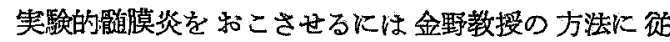
い. 正中線を避けて頭蓋骨壁に 直烽約 $0.5 \mathrm{~cm}$ の円形空 老作り，硬膜を露出し，溶連菌の $0.7 \%$ 生理的食塩水浮 游液 ( $1.0 \mathrm{cc}$ に 5 白食耳) の $0.2 \sim 0.3 \mathrm{ec}$ 硬膜下腔に注 入して起させた。

\section{III. 実験成績}

A. スルフアミン剂

1. ドミアン

ドミアン $0.2 \mathrm{~g}$ 経口投与ならびに $5 \%$ 溶淯 $1 \mathrm{cc}$ 静注 した場合の䯣畧内移行成續は第 1 裴ならびに第 1 図に示 した。

第1表 ドミアンの避沎内移行

(0.2g 経口投与ならびに $5 \%$ I cc 暗胍注射)

\begin{tabular}{|c|c|c|c|c|c|c|c|c|c|c|}
\hline & 7 & \multicolumn{2}{|c|}{7} & $30^{\prime}$ & 1 & 3 & 6 & 8 & 12 & 18 \\
\hline \multirow{4}{*}{$\begin{array}{l}\text { 柽 } \\
\text { 口 } \\
\text { 坆 } \\
\text { 标 }\end{array}$} & \multicolumn{2}{|l|}{ 血 } & 满 & & & 28 & 5 & 35 & 36 & 10 \\
\hline & \multirow{2}{*}{$\begin{array}{l}\text { 敷 } \\
\text { 液 }\end{array}$} & $\star$ & 憎 & & & & 08 & 1 & 27 & 0 \\
\hline & & 湍 & 陼 & & & & 08 & & 25 & \\
\hline & 造 & 进 & $\nLeftarrow$ & & & & 16 & 285 & 75 & \\
\hline \multirow{4}{*}{ 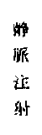 } & \multicolumn{2}{|c|}{4} & 满 & 102 & 87 & 56 & 3.3 & & & \\
\hline & $\$$ & 大 & 㥩 & 1. 6 & 23 & 2.8 & 1. 3 & & & \\
\hline & 淁 & 战 & 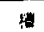 & & 22 & & & & & \\
\hline & 倍 & 时 & 移 & 156 & 264 & 50 & 393 & & & \\
\hline
\end{tabular}

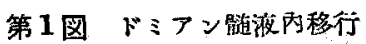

(0.2g 経口投与ならびに $5 \%$ 1cc 靜注)

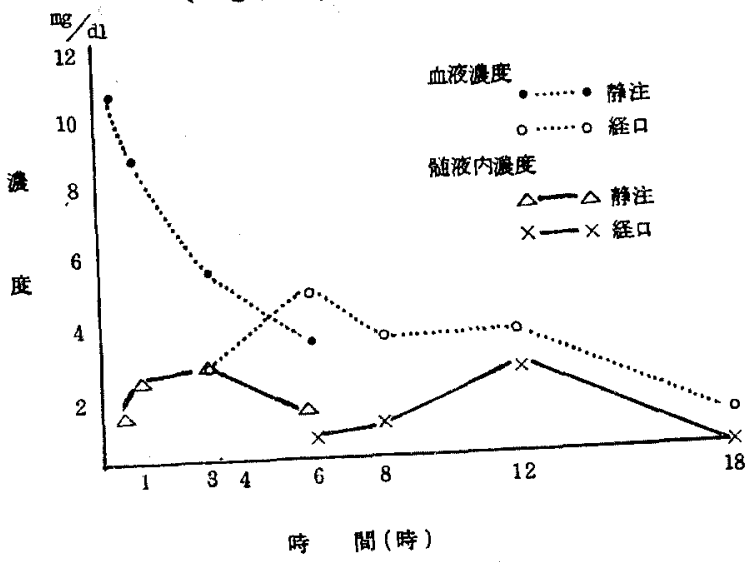

経口投与の垭合，血中澧度が最高に達する時間は内服 後 6 時間で，その丧度は平均 $5 \mathrm{mg} / \mathrm{dl}$ その際の䯣液内 清度は平均 $0.8 \mathrm{mg} / \mathrm{dl}$ で移行率は16である・その後血

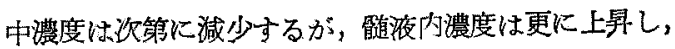




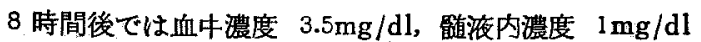
でこの時の 移行率は 28.5 である・髄液内濃度が最高に 達する時間は内服後 12 時間で, $2.7 \mathrm{mg} / \mathrm{dl}$ を示し，この 際の移行率は 75\% である，同時に湘定し得た 腰椎槽䯚 液内濃度は大槽内のるのとほとんど同じ程度である。

脈静注射の場合， 30 分後の血中澧度は $10.2 \mathrm{mg} / \mathrm{dl}$

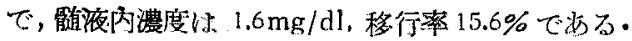

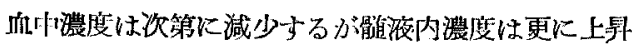
し， 3 時開後に最高に挂し， $2.8 \mathrm{mg} / \mathrm{dl}$ を示し移行 率 50\%である・

2. サイアジン

サイアデン $0.2 \mathrm{~g}$ 経口投与ならびに $5 \%$ 溶液 $1 \mathrm{cc}$ 静注した場合の蹎液内移行成樍は第 2 表ならびに第 2 図に示した。

第 2 表 サイアジン髄液內移行

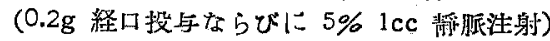

\begin{tabular}{|c|c|c|c|c|c|c|c|c|c|}
\hline & 7 & 时 & 30 & 1 & a & 4 & 6 & g. & 12 . \\
\hline \multirow{4}{*}{$\begin{array}{l}\text { 柾 } \\
4 \\
7\end{array}$} & 血 & 液 & & 82 & 68 & 80 & 78 & 68 & 5.6 \\
\hline & 蛆 & 大 & & & 038 & 09 & 1.4 & 21 & 019 \\
\hline & 将 & 祘 & & & & 0.6 & & 20 & \\
\hline & in & 油 & & & 5.6 & 112 & 129 & 39 & $a_{4}$ \\
\hline \multirow{4}{*}{ 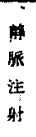 } & 血 & 菠 & 110 & 93 & 24 & 4.8 & & & \\
\hline & 徆 & 大 & 0.8 & 24 & 22 & a 3 & & & \\
\hline & 将 & 模 情 & & 12 & & & & & \\
\hline & 造 & 遇 革 & 7. 2 & 150 & 291 & 62 & & & \\
\hline
\end{tabular}

第。2图サイアジンの髄洨內移行 (0.2g 経田投与ならびに $5 \% 1 \mathrm{cc}$ 融渄)

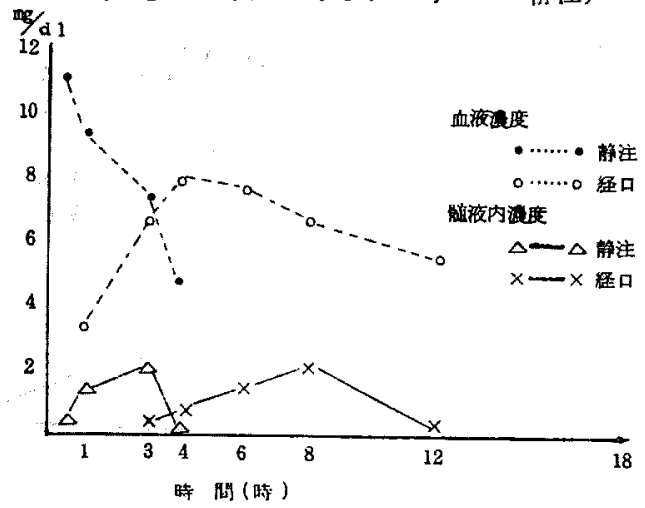

径口投与の場合，血中婊度が最高に達さる時間は投与 後 4 時間で, その濃度は $8 \mathrm{mg} / \mathrm{dl}$, その際の䯣殉内濃度 は $0.9 \mathrm{mg} / \mathrm{dl}$ で移行祭は $11.2 \%$ である・䯣液内濃度が 最高に洼与る持間は投与後 8 脚間で $2.1 \mathrm{mg} / \mathrm{d} 1$ であり， その移行率は $32 \%$ である. その後比較的速く減少し 12

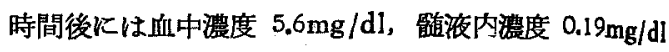
で，移行率は $3.4 \%$ である・

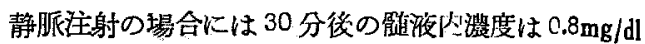
で移行率は $7.2 \%$ である・その後䯣液内浀度は急速以上 年し，3時間で最高に達し，その後は再び急速に減少与

第 3 表 スブロナール髄湤內移行

(0.2g 経口投与ならびに $5 \% 1 \mathrm{cc}$ 静胍注射)

\begin{tabular}{|c|c|c|c|c|c|c|c|c|c|c|}
\hline & & 㛺 & & $30^{\prime}$ & 1 & 3 & 4 & 6 & 8 & 12 \\
\hline \multirow{4}{*}{$\begin{array}{c}\text { 程 } \\
\text { 口 } \\
\text { 投 } \\
\text { 与 }\end{array}$} & \multicolumn{2}{|l|}{ 血 } & 挔 & & 21 & 82 & 26 & 72 & 56 & 31 \\
\hline & \multirow[t]{2}{*}{ 知 } & 大 & & & 1.0 & 23 & 38 & 3.5 & 24 & 15 \\
\hline & & 腰 & 错 & & & 12 & & 32 & & 25 \\
\hline & 逝 & 造 & & & 4.7 & 287 & 405 & 489 & 431 & 422 \\
\hline \multirow{4}{*}{$\begin{array}{l}\text { 首 } \\
\text { 注 } \\
\text { 射 }\end{array}$} & 血 & & 㖡 & 133 & 104 & a 3 & 37 & & & \\
\hline & \multirow{2}{*}{$\begin{array}{l}\text { 㭗 } \\
\text { 液 }\end{array}$} & 太 & 棈 & 1.2 & 25 & 3.1 & 28 & & & \\
\hline & & 限 & 指 & & 21 & 28 & & & & \\
\hline & 造 & 迾 & 率 & 90 & 240 & 492 & 486 & & & \\
\hline
\end{tabular}

第 3 図 スプロナールの艏液內移行 (0.2g 経曰投与ならびに $5 \%$ 1 cc 靜泩)

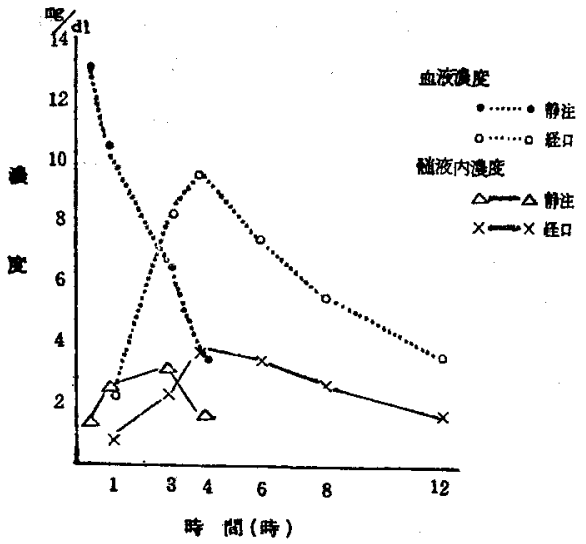

る・飭液内濃度の最高平均偲は $2.2 \mathrm{mg} / \mathrm{dl}$ で，移行率 $29.1 \%$ である・

$$
\text { 3. スプロナール }
$$

スプロナール0.2g 経口投与ならびK $5 \%$ 溶夜 Icc 静 注した場合の䯣液内移行成績は第 3 表ならびに第 3 图沉 示した。

経口投与の場合，血中濃度之髄液内濃度が最高炕達寸 る時間は共に投与後 4 時間である・その後血中償度は次 第に減少してゆくが，艏夜内濃度の減少してゆく割合は 綬慢で投与後 12 時間にわたつて $45 \%$ 内外の移行率を示 している・同時と測定し得た腰椎槽内䟴度は大槽内清度 と任が同程度である。

静脈注射の埸合には 30 分後の血中濃度が $13.3 \mathrm{mg} / \mathrm{dl}$ 
で，夠液内濃度は $1.2 \mathrm{mg} / \mathrm{dl}$, 移行率 $9.0 \%$ である・

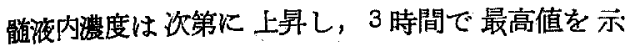
し，この時の移行翠は 49.2\%である・な持 6 時間 後に扔いても䯣淮队檂度 $1.8 \mathrm{mg} / \mathrm{dl}$ を示し 移行率 $48.6 \%$ である・又同時に测定し得た腰椎槽内濃度 は大槽内のものとほとんど同じである。

\section{B. 抗生物質}

1. ペニシリン

ペニシリン2万単位筋注ならびに1万単位静注し 大場合の䯣液内移行成績は第 4 表に示した。

正常家鬼の場合

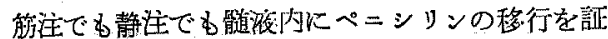
明することができない

\section{骮獏炎家東の場合}

筋注では 30 分後は全例に 移行を部明し得なかつ たが，1 㭙間後では 19 例中 3 例に $0.015 \mathrm{u} / \mathrm{cc \sim 0.03}$ $\mathrm{u} / \mathrm{cc}, 2$ 侍間後では 18 例中 6 例任 $0.02 \mathrm{u} / \mathrm{cc} \sim 0.058$ $\mathrm{u} / \mathrm{cc}, 3$ 時間後では 20 例中 7 例に $0.02 \mathrm{u} / \mathrm{cc} \sim 0.04$

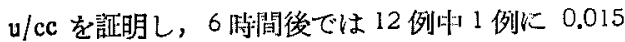
u/cc を測定し得たに過ざない。

すなわち 1 時間から 3 恃間の間に比較的移行を証 明する回数は多いが，走れにしても 全測定数 57 例 中16例認められたにすぎず，その移行量も 0.15 〜 0.058 u/cc の低漂度である。

静注の埸合には30 分後に 14 例中 2 例に $0.03 \mathrm{u} /$ cc を証明し，1時間後には 14 例叶 5 例に $0.025 \mathrm{u} /$ $c c \sim 0.09 \mathrm{u} / \mathrm{cc}, 2$ 時間後に 15 例中 5 例飞 $0.02 \mathrm{u} / \mathrm{cc}$ $\sim 0.05 \mathrm{u} / \mathrm{cc}, 3$ 時間後では 11 例中 2 例飞 $0.02 \mathrm{u} / \mathrm{cc}$, $0.036 \mathrm{u} / \mathrm{cc}, 6$ 時間後では 12 例中 2 例飞 $0.02 \mathrm{u} / \mathrm{cc}$, 0.025u/ccを証明したにすぎない。

すなわち静往の場合でも筋注の焬合でも約 $2 / 3$ K 移行が諗められず，移行する場合でもその移行量は 低簏度である。

2. ストレプトマイシン

ストレプトマイシン 1/25g を筋注ならびに静注 しな場合の能迹液内移行成續は第 5 表に示した。

\section{正常家鬼の場合}

筋注では 1 時間から 3 時間の間に移行の証明され ることがある・すなわち 1 時間では 12 例中 4 例に $0.17 \sim 0.5 \mathrm{r} / \mathrm{cc}$ が湘定され，2 時間では 16 例中 5 例 に $0.3 \sim 1.4 \mathrm{r} / \mathrm{cc} ， 3$ 時間では 6 例中 2 例に $0.2 \mathrm{r} / \mathrm{cc}$ ， $0.5 \mathrm{r} / \mathrm{cc}$ が認められたが，6時間では全例陰性であ る.
第 4 表 ペニシリンの鮪液肉移行

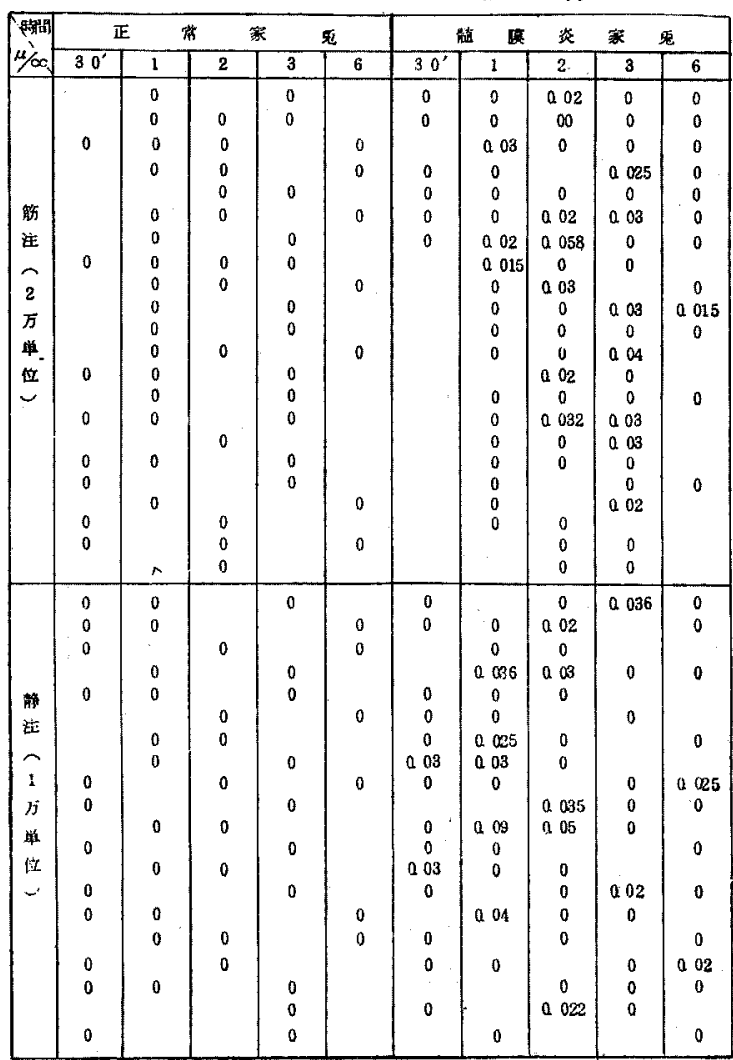

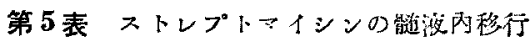

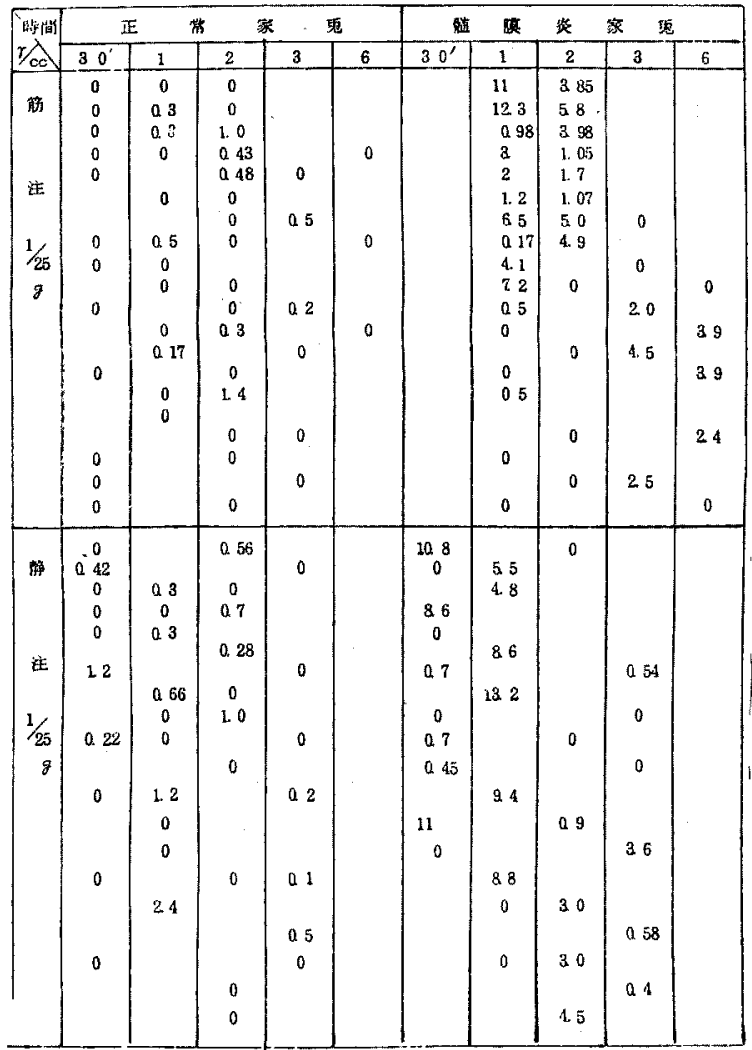


静注の場合は, 30 分で 10 例中 3 例に $0.22 \sim 1.2 \mathrm{r}$ /ccが認められ，1時間で 10 例中 5 例に $0.3 \sim 2.4 \mathrm{r}$ / cc, 2 時間で 10 例中 4 例佂 $0.28 \sim 1,0 \mathrm{r} / \mathrm{cc}, 3$ 時間 では7例中 3 例に $0.1 〜 0.5 \mathrm{r} / \mathrm{cc}$ が認められた。

すなわち 正常家鬼の埸合にも証明することがあ り，その頻度は筋注の場合火は 1 時間から 3 時間を でよ゙，その全測定数 34 例中 11 例，静注の場合火は 30 分から 3 時間までら゙，その全测定数 37 例中 15 例である・しかし移行濃度は大部分が $\mathrm{rr} / \mathrm{cc}$ 以下 の低澧度である・また時間の経過に伴ら移行量の特 徵はは之んどないが，筋注の場合は 2 時間, 静注の 場合は 1 時間に比較的高濃度が認められる。

䯙膜炎家震の場合

筋注の場合，1時間では 16 例中 12 例に 0.17 $12.3 \mathrm{r} / \mathrm{cc} ， 2$ 時間では 12 例中 8 例に $1.07 \sim 5.8 \mathrm{r} / \mathrm{cc}$, 3 時間では 5 例中 3 例飞 $2.0 \sim 4.5 \mathrm{r} / \mathrm{cc}, 6$ 時閒で 5 例 中3例に $2.4 \sim 3.9 \mathrm{r} / \mathrm{cc}$ が竐明される。

静注の場合には 1 時間では8 例中 6 例に 4.8 $13.2 \mathrm{r} / \mathrm{cc}, 2$ 時間では 6 例中 4 例炕 $0.9 \sim 4.5 \mathrm{r} / \mathrm{cc}, 3$ 時間で 6 例中 4 例に $0.4 \sim 3.6 r / \mathrm{cc}$ を証明する。

すなわち，筋注の場合と静注の埸合との差は汪と んどなく，全測定数 68 例中 46 例に骮液内移行が証明さ れるが，ストレプトマイシンの結核菌に対する最低有効 濯度が $6.25 \mathrm{r} / \mathrm{cc}$ ，肺炎双球菌に対しては $6.3 \sim 5.0 \mathrm{r} / \mathrm{cc}$ であるから有就濃度の点からみれば，これ以上を証明で きたるのは68例中 11 例㣙ざない

3.クロルテトラサイクリン（オーレオマイシン）

クロルテトラサイクリン $10 \mathrm{mg} / \mathrm{kg}$ を筋注ならびに静 注した場合の䯕液内移行成績は符 6 表に示した・

正常家㭸の場合

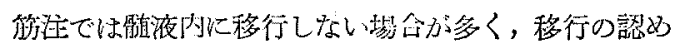

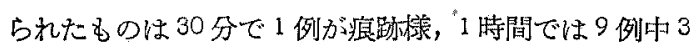
例が痕䟢様で， 1 例が $0.003 \mathrm{r} / \mathrm{cc}, 2$ 時間では 9 例中 2 例 が痕䟞様，2 例が $0.005 \mathrm{r} / \mathrm{cc}, 0.006 \mathrm{r} / \mathrm{cc}, 3$ 時間では 6 例 中 2 例が痕跡様，1 例が $0.005 \mathrm{r} / \mathrm{ccc} 6$ 特間では移行を証 明しないかあるいは痕踪様となる。

静注の場台注移行を証明しなからた埸合が少く，僅か に2時間と6時間にそれぞれ1例あるにすぎないすすな わら正常家秉の場合でも静注すればよく䯣液队移行 乙，30 分では痕跡㥞が 1 例，他の 3 例は $0.01 \sim 0.025 \mathrm{r} /$ cc，1時間では 2 例方痕跡㥞 6 例は $0.003 \sim 0.13 \mathrm{r} / \mathrm{cc}, 2$ 㭙: 閒では移行を試明し得なからたもの1例, 痕跡様 1 例で 他の6 例では $0.006 \sim 0.035 \mathrm{r} / \mathrm{cc}$, 3 㭙間では2 例が痕䟞様,
第6表 クロルテトラサイクリン（ォーレオ

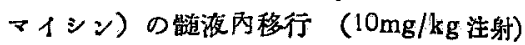

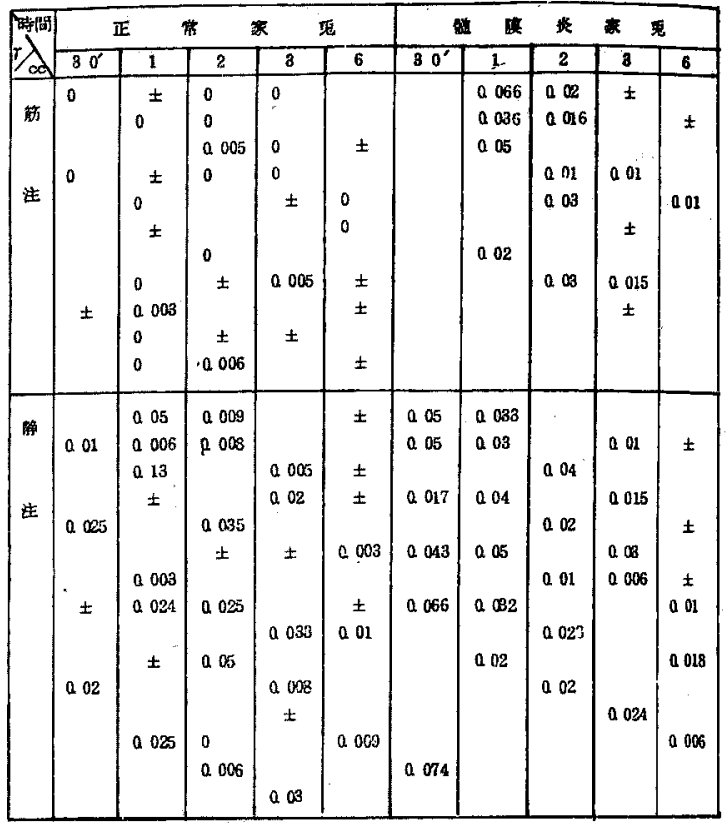

5 例は $0.005 \sim 0.03 \mathrm{r} / \mathrm{cc}$ となり，6時間では移行を証明 しなかつたものI例, 痕跡椂 4 例で, 3 例扎いて 0.003 $\sim 0.01 \mathrm{r} / \mathrm{cc}$ が証明される。

骮獏炎家臣の場合

笳注の場合には 1 時間で $\quad 0.02 \sim 0.066 \mathrm{r} / \mathrm{ccc}, 2$ 時間で $0.016 \sim 0.03 \mathrm{r} / \mathrm{cc}, 3$ 時間では痕跡樣が 3 例, 他の 2 例性 $0.01 \sim 0.015 \mathrm{r} / \mathrm{cc}, 6$ 時間では 1 例痕跡様, 1 例 $0.01 \mathrm{r} / \mathrm{cc}$ である・

静注では 30 分で 0.043 0.17r/cc，1 時間では 0.02 $0.05 \mathrm{r} / \mathrm{cc}, 2$ 時間で $0.01 \sim 0.04 \mathrm{r} / \mathrm{cc}, 3$ 時間で $0.006 \sim 0.03$ $\mathrm{r} / \mathrm{cc}, 6$ 㸡間では痕跡㥞 3 例，他の 3 例では 0.006 $0.018 \mathrm{r} / \mathrm{cc}$ である.

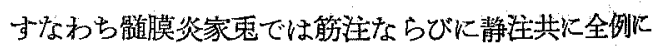
䯣液内移行を認めるが，正常家鬼に比して幾分移行量が 増加している程度である・

テトラサイクリン系統の抗生物質の最小発育阻止整度

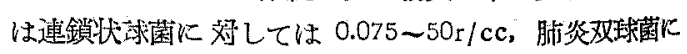
刘しては 0.02〜1.0r/cc であるから，今最小有效濃度を 0.02〜 $0.075 \mathrm{r} / \mathrm{cc}$ とすれば，これ以上を証明できた例は助 注では 1 時間 4 例， 2 時間 3 例で 3 时間以後には癹めら れない. 静注では 30 分 6 例, 1 時間 6 例, 2 時間 4 例, 3 時間 2 例で 6 時間では認はめられない。すなわら有效 
瀑度の点がらみれば，全湘定数 44 例中 25 例飞認めら れ，約 $50 \%$ の有効濃度の移行が認められる。

$$
\text { 4.オキシテトラサイクリン(テラーイシン) }
$$

オキシテトラサイクリン $10 \mathrm{mg} / \mathrm{kg}$ を筋注ならびル静 注した埸合の䯣液内移行成績は第? 表に示した。

第7表 オキシテトラサイタリン（デマイシン） 心随沎肉移行

( $10 \mathrm{mg} / \mathrm{kg}$ 湴射)

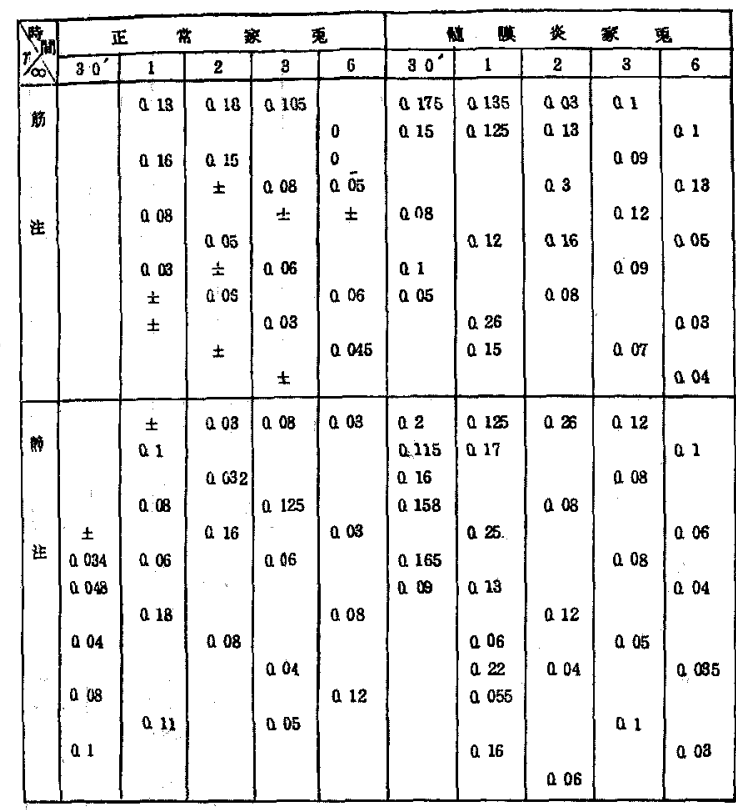

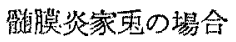

能注では1時間 $0.12 \sim 0.26 \mathrm{r} / \mathrm{cc}, 2$ 時閂 $0.03 \sim 0.3 \mathrm{r} / \mathrm{cc}$ ， 3 時間 $0.07 \sim 0.12 \mathrm{r} / \mathrm{cc} ， 6$ 㭙間 $0.03 \sim 0.13 \mathrm{r} / \mathrm{cc}$ で全例に 移行が証明される。

静注の寫合汇子 30 分 $0.09 \sim 0.2 \mathrm{r} / \mathrm{cc}, 1$ 時問 $0.055 \sim$ $0.25 \mathrm{r} / \mathrm{cc}, 2$ 㭙間 $0.04 \sim 0.26 \mathrm{r} / \mathrm{cc}, 3$ 時間 $0.05 \sim 0.12 \mathrm{r} / \mathrm{cc}$ ， 6 時阔 $0.03 \sim 0.13 \mathrm{r} / \mathrm{cc}$ の移行が証明される。

一なわら骵膜炎家覌の埸合は筋注でる全例に移行 が諗められ，正常家鬼に比して幾分移行量の壇加が 琵如放る。

オキシテトシサイクリンの最小有效婊度を 0.07 r/ccとすればここれ上上を証明したものは䯣膜炎 家鬼の埸合，筋注では 1 時間 5 例中 5 例， 2 時間 5 例中 4 例， 3 時間 5 例中 5 例， 6 時間 5 例中 2 例で あり，背注では30分6 例中6 例，1時閏 8 例中 6 例， 2 時間 5 例中 3 例，3時間 5 例中 4 例，6時間 5 例中 1 例で，全测定数 54 例中 40 例 $(74.1 \%)$ に有

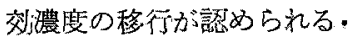

$$
\text { 5. テトラサイクリン（アクローイシン） }
$$

テトラサイクリン $10 \mathrm{mg} / \mathrm{kg}$ を笳注ならびに静注 した埸合の䯚淮内移行成績は第8素に示した・

\section{正掌家鬼の場合}

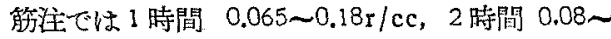
$0.2 \mathrm{r} / \mathrm{cc}, 3$ 時間 $0.08 \sim 0.2 \mathrm{r} / \mathrm{cc}, 6$ 時間 $0.06 \sim 0.14 \mathrm{r} /$ cc で全例に移行が誌められる・

第 8 表 テトラサイタリン（アクロマイシン） の雊液队移行

(10mg/kg 注射)

\section{正常家愁の埸合}

解注では1時間で移行の証明されないるの1例， 痕跡様のもの 2 例で，他の 4 例は $0.03 \sim 0.16 \mathrm{r} / \mathrm{cc}$, 2 時間では痕跡樣のおの3 例で，他の 4 例は 0.05〜 $0.18 \mathrm{r} / \mathrm{cc}, 3$ 赫間では痕跡様のもの2例，他の 4 例は 0.03 0.105r/cc, 6時間では移行の認められないる の2例，痕跡様のもの1例で他の3 例では 0.045〜 0.06 r/cc である。

静脈注射の場合には全例に䯣液内移行が認められ る.すなから30分では痕跡症1 例で他の5 例では

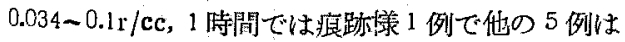
$0.06 \sim 0.18 \mathrm{r} / \mathrm{cc}, 2$ 㭙間では $0.03 \sim 0.16 \mathrm{r} / \mathrm{cc}, 3$ 㭙间 では $0.04 \sim 0.125 \mathrm{r} / \mathrm{cc}$ ，6特閏では $0.03 \sim 0.12 \mathrm{r} / \mathrm{cc}$ である。

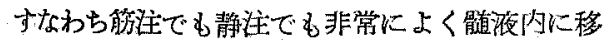
行して挌り，静注では全例に移行が証明され，朌注

\begin{tabular}{|c|c|c|c|c|c|c|c|c|c|c|}
\hline & I & & 5 & & & 解 & 暯 & 菼 & 家 & $\because$ \\
\hline & $30^{\circ}$ & 1 & 2 & 3 & 6 & $80^{\prime}$ & 1 & 2 & 3 & 6 \\
\hline 注 & $\begin{array}{l}0.04 \\
0.03 \\
\pm \\
0.035 \\
0.035\end{array}$ & $\begin{array}{l}\text { a. } 16 \\
\text { Q. } 09 \\
\text { 0. } 065 \\
\text { Q. } 18\end{array}$ & $\begin{array}{l}0.16 \\
a \quad 08 \\
a .2 \\
a \quad 12 \\
0.14\end{array}$ & $\begin{array}{l}0.18 \\
0.08 \\
\text { a. } 25 \\
\text { a.2 } \\
\text { Q. } 12\end{array}$ & $\begin{array}{l}0.06 \\
0.07 \\
0.06\end{array}$ & $\begin{array}{l}0.23 \\
0.3 \\
0.09 \\
0.16 \\
0.065\end{array}$ & $\begin{array}{l}0.35 \\
0.15 \\
0.22 \\
0.16 \\
0.3\end{array}$ & $\begin{array}{l}a 31 \\
03 \\
034 \\
0.43 \\
0.07\end{array}$ & $\begin{array}{l}a 2 \\
0.18 \\
\text { a } 21 \\
0.09 \\
a 08\end{array}$ & $\begin{array}{l}0.16 \\
0.18 \\
0.06 \\
0.06 \\
0.08 \\
0.2\end{array}$ \\
\hline 注 & $\begin{array}{l}0.04 \\
0.09 \\
0.04\end{array}$ & $\begin{array}{l}0.13 \\
0.06 \\
a .15 \\
0.2 \\
0.16\end{array}$ & 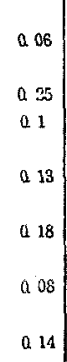 & $\begin{array}{l}0.2 \\
a .07 \\
0.08 \\
a .16 \\
0.3 \\
0.16\end{array}$ & $\begin{array}{l}0.08 \\
0.07 \\
0.1\end{array}$ & $\begin{array}{l}a .25 \\
a 2_{23} \\
0.36 \\
0.55 \\
0.08\end{array}$ & 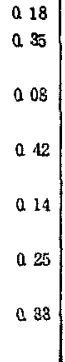 & $\begin{array}{l}0.8 \\
0.68 \\
0.9 \\
0.15 \\
0.39 \\
0.45 \\
0.4 \\
0.03\end{array}$ & $\begin{array}{l}0.22 \\
0.08 \\
a 16 \\
01 .\end{array}$ & $\begin{array}{l}0.2 \\
0.12 \\
0.05 \\
0.04 \\
0.32\end{array}$ \\
\hline
\end{tabular}
ては26 例山15 例 $(57.7 \%)$ に移行が諗められる。 
静注では30 分 $0.03 \sim 0.12 \mathrm{r} / \mathrm{cc}, 1$ 郝間 $0.06 \sim 0.23$ $\mathrm{r} / \mathrm{cc}, 2$ 特間 $0.06 \sim 0.25 \mathrm{r} / \mathrm{cc}, 3$ 時間 $0.07 \sim 0.3 \mathrm{r} / \mathrm{cc}$, 6 時間では痕跡様 1 例で他の 5 例では $0.05 \sim 0.16 \mathrm{r} /$ ccである・

\section{骵朕炎家禹の埸合}

等注では 30 分 $0.055 \sim 0.3 \mathrm{r} / \mathrm{cc}, 1$ 㭙間 $0.15 \sim 0.35$ $\mathbf{r} / \mathrm{cc}, 2$ 时间 $0.07 \sim 0.43 \mathrm{r} / \mathrm{cc}, 3$ 跀間 $0.08 \sim 0.21 \mathrm{r} / \mathrm{cc}$ ， 6 時間 $0.06 \sim 0.2 \mathrm{r} / \mathrm{cc}$ である。

静注では 30 分 $0.08 \sim 0.36 \mathrm{r} / \mathrm{cc}, 1$ 㸡間 $0.08 \sim 0.42$ $\mathrm{r} / \mathrm{cc}, 2$ 時間 $0.06 \sim 0.9 \mathrm{r} / \mathrm{cc}, 3$ 㭙間 $0.008 \sim 0.3 \mathrm{r} / \mathrm{cc}$, 6 時間では $0.04 \sim 0.32 \mathrm{r} / \mathrm{cc}$ である.

すなわちテトラサィタリンは正常家蚛でる髁膜炎 家束でも全例が移行して括り，髄膜炎家鬼の場合に は3時間までは移行量の增加が認められるが，3時 間後では正常家鬼の移行率之大差は誌められない。

テトラサイクリンの最小有效濃度を $0.07 \mathrm{r} / \mathrm{cc}$ と すれば，䯣膜炎家秉の場合，少くとす6時間までは 有効濃度の移行が期待される・

6. クロラムフエニニル（クロロマイセテン）

クロシムフェニコル $10 \mathrm{mg} / \mathrm{kg}$ を的注ならびに静 注した場合の䯙淮内移个成續は第9亜に示した・

正常家鬼の埸合

筇注では 30 分 4 例中 2 例は痕跡椂， 2 例《: 0.86 $\sim 1.0 \mathrm{r} / \mathrm{cc}, 1$ 時間 $1.9 \sim 4.2 \mathrm{r} / \mathrm{cc}, 2$ 持間 2.9 5.2r/ $\mathrm{cc}, 3$ 時間 $1.2 \sim 2.5 \mathrm{r} / \mathrm{cc}, 6$ 時闖 $1.0 \sim 2.1 \mathrm{r} / \mathrm{cc}$ の移行 が認められる・

静注では 30 分 1.3〜 4.8r/cc, 1 時間 $1.2 \sim 5.5 \mathrm{r} / \mathrm{cc}$, 2 時間 $1.6 \sim 3.7 \mathrm{r} / \mathrm{cc}, 3$ 時間 $1.6 \sim 3.2 \mathrm{r} / \mathrm{cc}, 6$ 時間 1.2 $\sim 2.2 \mathrm{r} / \mathrm{cc}$ で全例とも相当の移行度を示している。 また筋注，静注との差はあまり諗められない。

\section{䯣慕炎家鬼の場合}

筫注では 30 分 $1.3 \sim 3.6 \mathrm{r} / \mathrm{cc}, 1$ 時間 $2.3 \sim 6.0 \mathrm{r} / \mathrm{cc}$ ， 2 時間 $2.5 \sim 5.6 \mathrm{r} / \mathrm{cc} ， 3$ 時間 $1.7 \sim 5.3 \mathrm{r} / \mathrm{cc}, 6$ 時間 1.6〜4.3r/cc の移行が認められる・

静注の埸合には 30 分 $3.8 \sim 5.0 \mathrm{r} / \mathrm{cc}, 1$ 時間 $4.4 \sim$ $8.5 \mathrm{r} / \mathrm{cc}, 2$ 時間 $2.4 \sim 6.8 \mathrm{r} / \mathrm{cc}, 3$ 時間 $1.4 \sim 3.5 \mathrm{r} / \mathrm{cc}$, 6 時間 1.5〜2.3r/cc の移行が認められる。

クロテムフェニコルの連鎖球菌に刘する最小発 青阻止濃度は 0.75 50r/cc, 肺炎球菌に対しては 0.312 〜2.5r/cc であるから，今最小有傚澧度を $0.7 \mathrm{r} / \mathrm{cc}$ とす ればこれ以上を証明したものは6時間までの全例であ Ђ.
第9表 クロシムフエニコル（クロ、ー1セダン） の蜘澡文移行

$(10 \mathrm{mg} / \mathrm{kg}$ 注射)

\begin{tabular}{|c|c|c|c|c|c|c|c|c|c|c|}
\hline 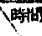 & I & & & & & $\pi$ & 缜 & * & 澳 & \\
\hline$r / \infty$ & $80^{\prime}$ & 1 & 2 & 3 & 6 & $80^{\circ}$ & 1 & 2 & 8 & 6 \\
\hline & (1) 86 & $\begin{array}{l}26 \\
1.9\end{array}$ & a 2 & $\begin{array}{l}25 \\
12\end{array}$ & $\begin{array}{l}13 \\
16\end{array}$ & 13 & 60 & 25 & 23 & 18 \\
\hline 埇 & \pm & & 36 & & & 28 & 46 & 25 & & \\
\hline & & 20 & & 2.7 & 2.1 & & 40 & & 21 & 22 \\
\hline & & & 52 & & & 26 & & 84 & & \\
\hline & t & 42 & & & & & 30 & 48 & S. 3 & 4.8 \\
\hline & & & 39 & 1.8 & l. 25 & 36 & 28 & & 1.8 & \\
\hline & 1.0 & 11 & & 1. 6 & & & 56 & 55 & & 26 \\
\hline & & & 33 & & 1.5 & & & & 22 & 28 \\
\hline & & 32 & & 25 & 10 & & 38 & 56 & 17 & \\
\hline & & & 29 & 1. 2 & & & & 36 & & 16 \\
\hline 注 & & 28 & & 1.8 & 11 & & 23 & & 18 & \\
\hline & & a 2 & 1. 2 & 16 & & & & & & \\
\hline & 182 & 1.2 & 18 & 22 & L. 3 & 4.4 & 50 & & $\$ 2$ & 28 \\
\hline & 2.8 & 25 & & 16 & 23 & 86 & & a 2 & & \\
\hline 票 & 18 & & 22 & & & & 80 & 24 & 22 & 21 \\
\hline & & 25 & 37 & a 2 & 12 & 42 & 6.4 & 52 & 25 & 18 \\
\hline & 18 & 55 & 30 & & & E. 0 & & & 27 & 16 \\
\hline & 30 & 48 & & 28 & 18 & & 44 & 46 & & \\
\hline & & 55 & & 25 & 22 & 40 & 76 & 82 & 16 & 16 \\
\hline 注 & 3.1 & & 16 & & 29 & 45 & 85 & 34 & 21 & 16 \\
\hline & & 27 & 87 & 30 & & 88 & & 6.8 & & 18 \\
\hline & & & & & & & 53 & & 14 & \\
\hline
\end{tabular}

第 10 表 エリスロマイシン（アイロタイシン） の髄淮內移行

$(10 \mathrm{mg} / \mathrm{kg}$ 注射)

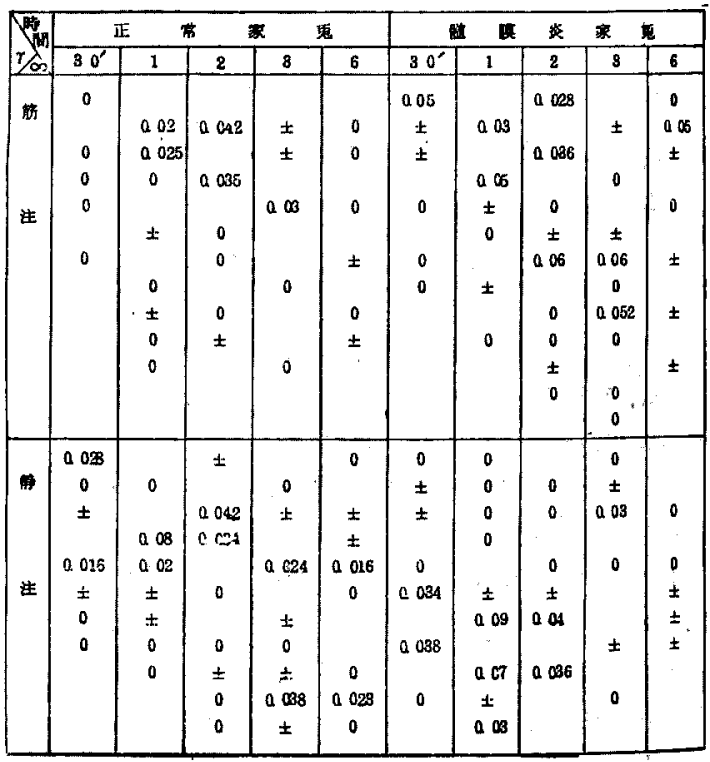

7. エシスローイシン (フィロタイシン)

エリスロマイシン $10 \mathrm{ng} / \mathrm{kg}$ を筇注ならびに 静往し た埸合の䯣液内移行成續は第 10 表に示した・

正常家鬼の場合 


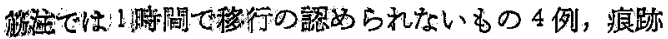
嵄 2 例，他の 2 例は $0.02 \sim 0.025 \mathrm{~s} / \mathrm{cc} ， 2$ 時間で移行の認

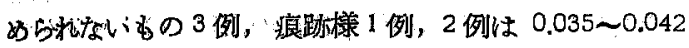
$\mathrm{r} / \mathrm{kg} ， 3$ 時間では 1 例に $0.03 \mathrm{r} / \mathrm{cc}$ を䜅めるが，，2 例は痕

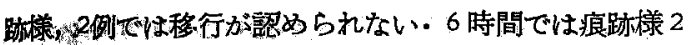

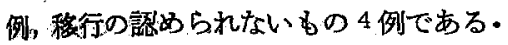

静注て杜 30 分て移行の 認められない子の3 例, 痕跡 様2例で他の 2 例では $0.016 \sim 0.028 \mathrm{r} / \mathrm{cc}$ ，1 時間では 2

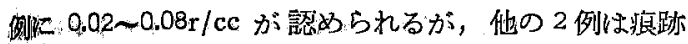

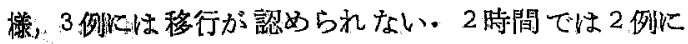
0.034〜0,042r/cc，が認められるが，4 例には移行が認め

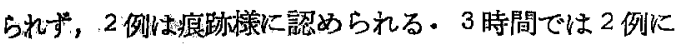
0,024 0.038r/cc，2 例には移行が認められず，4 例は痕 跡様汽認められる.6時間では 2 例に $0.016 \sim 0.023 \mathrm{r} / \mathrm{cc}$ ，

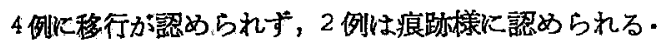

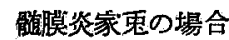

䇟註では 30 分 6 例中 1 例 $0.05 \mathrm{r} / \mathrm{cc}, 2$ 例痕䟞様， 3 例 结行が認められない..1時間では 6 例中 2 例 0.03 $0.05 \mathrm{r} / \mathrm{cc} ， 2$ 例痕跡様，2例《移行が認められない，2時

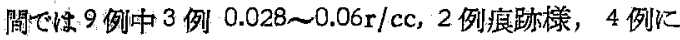
移行が認めら礼ない，3時間では9例中 2 例に 0.052 0:06r/cc が認められるが 2 例は痕跡样，5 例に移行が認 められない６時間では7 例中 1 例飞 $0.05 \mathrm{r} / \mathrm{cc} ， 4$ 例が 痕踢様で 2 例俰行が認められない。

静注では 30 分 7 例中 2 例 $0.034 \sim 0.038$ r/cc. 2 例泿跡

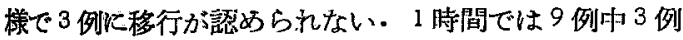

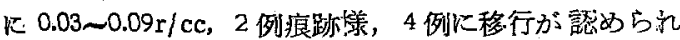
ない2 時間では 6 例中 2 例加 $0.036 \sim 0.04 \mathrm{r} / \mathrm{cc} ， 1$ 例痕 跡様，3例炕移行が認められない。3時間では6 例中 1 例 $0.03 \mathrm{r} / \mathrm{cc}, 2$ 例痕跡様で 3 例飞移行が認められない. 6 時間では痕跡様 3 例で移行の認められないもの 2 例であ る.

エリスロマイシンの連鑟球菌に対する最小発育阻止濃 度は 0.02 3.1 r/cc であり，肺炎球菌に 対しては 0.01 〜 0.156r/cc であるから今最小有效濃度を $0.02 \mathrm{r} / \mathrm{cc}$ とす ればこれ以上を証明し得たるのは䯣脱炎家鬼の場合， 肪注では 30 分 6 例中 1 例， 1 時間 6 例中 2 例， 2 時間 9 例中 3 例， 3 時間 9 例中 2 例， 6 時間では 7 例中 1 例で 西り，静注の境合炕性 30 分 7 例中 2 例， 1 時間 9 例中 3 例，2 時間6 例中 2 例，3 時間 6 例中 1 例である.すな わち 能注と静注との 差はなく，雨者を通じて 全测定数 70 例中，有効濃度の移行が認められたのは17 例であ る.

\section{IV. 䋓括並びに考按}

以上の成績を総括すると，スルフアミン剂では経口投 与の場合，血中濃度は 4〜6 時間で 最高を示し，鲔液内

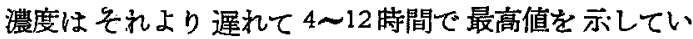
る・すなわちドミアンは 12 時間でその際の移行率は 75 \%，サイアジンは 8 時間で移行率 32\%，スブロナールは 4 赙間で移行率 40.5\% である・静脈注射の場合には注射 後 3 㭙䦎で最高に達して和り，その移行率はドミアン 50\%，サ1アジン 29.1\%，スプロナール49.2\%である。

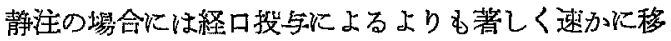
行しているが，移行濃度では経口投与群と大差なく，ま た䯣夜内消長も極めて類似している・したがつて最初の 急を要する場合には静注が優れているが，その後の静唯 队有効洤度を保つためには内服によるのが実際にかなつ ていると考えられる。

移行率についてみるとドミアンが最高で，次でスプロ テール，サイアジンの順である・

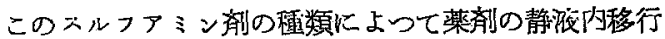
の程度を異にすることについては Krebs \& Speakman は赤血球，血墏間の分布と同樣解離の点を考慮する必要 があると述べ，Shannon す亦解離恒数はスルフアミン

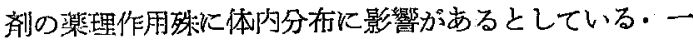
加 Davis 等性電気泳動法により血獎均でアルブミンに スルフアミン用の吸着されることを実䮦し，その強さは スルフアニールアマイド $20 \%$ ，スルフアピリジン $40 \%$ ， スルフアテアゾール75\%，スルフフダイアジン55\%で あるとし，またてグロブリンには吸着されないことを

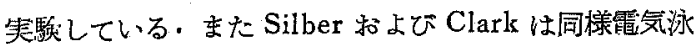
動法によりスルフアダイアジンについて血㧛内でアルブ ミンに䴔する吸着度を $62 \%$ としている・真下も血漿蛋 白質との結合能はスルフアチアゾールが最大で，スルフ アダイアジン，スルフアピリジンがこれにつぐことを証 明し，平井はスルフアニールアマイド，スルフアナアゾ 一ル，スルフアダィアジンの血漿アルブミンに哿する絬 合度はそれそれ $17 \% ， 71 \% ， 63 \%$ であると報告してい

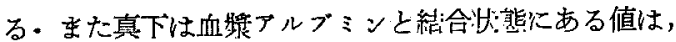
髄膜正常の場合スルフアニールアマ1ド，スルフアテア ゾール，スルフアダイアジンがをれぞれ39\%,95\%，88 \%であり，変性梅毒等で髄滩にグロブリン增加のあるに

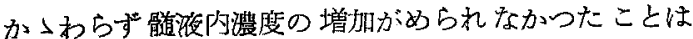
Davis の笑験結果スルフアミン剂がとグロブリンと結 合しないという事を裏畫するあのであり，さらにスルフ

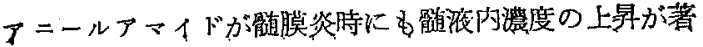


明でないこともアルフミンに対する吸着度が最も少い点 から説明できると述べ，これらスルフアミン郕はそれぞ れ解離恒数の異なる両性電解質であり，血液内において 赤血球括よび㔻白質の量叔よび性筫さらに $\mathrm{pH}$ に影響 されて分布状熊を異にして拉りそのらち䯠液内に移行し らるのはいかゆる血液艏液閤門が正常であり血管壁の透 過性の正常なるかぎりに执いてはすず血液内で赤血球括 よびアルプミンと結合状態にある上外の遊離状態にある ものと考え，スルフアミン刘に関しては血液䯘液関閒の 機能は一見撰択的であるごとくにみえるがその本質にお いては㴗怙よび拡散によるものであり，スルフアミン 郕の体内活動機転ことに血液より楽風の血管外之の移行 の根本は血液内分布の状態䄮よび血管壁の状態に左右さ れると述べている。

飯塚は経口投与扣よび頸動脈注射の両群が時間的の善 はあるが，蜘網医下腙门各·部の髄液濃度の消長からみて 極めて類似して怙り，側脳室扣よび脳蜘網膜下腔の濃度 が常に同樚度にあることを知り，さらに経口投与脳堙痬 群で蜘網膜下腔の局在的透過性の顕著な充進を認めたこ とからスルンフミン郕の血液随液関門の所在は，広く䇥 網膜下腟内壁を形成する軟膜执よび脈絡叢の全毛絧血管 にありと推定している.

私のスルファミン郕の移行成積からみても経口投与な らびに静注の際に同時に採取した大槽ならびに腰槽内䯣 液濃度に大差なくその消長わ極めて似ている点から考完 ても血液随液関門が従来言われているよらに脈絡叢のみ にあるとは考えられない。

抗生物質についてみると，正常家鬼の場合にはぺニシ シンは笳注でも静注でも䯣液内に移行を証明し得ない。 ストレプトマイシンは筋注の場合は 49 例中 11 例 (22.4 $\%)$ ，静注では 37 例中 15 例 (40.5\%) 飞移行が証明さ れる・クロルテトラサイクリンは明らかに移行の認めら れたるのは筋注では 33 例中 4 例 (12.1\%)，静注では 35 例中 23 例 $(65.7 \%)$ あり，痕跡様のものも含めると，筇 注では48.4\%，静注では94.2\%である・オキシテトラサ イクリンでは明らかル移行の認められたるのは筋注 26 例中 15 例 $(57.7 \%)$ ，静注 25 例中 23 例 $(92.0 \%)$ であ り, 痕跡憎のもの子含める上䶼注 26 例中 23 例 (88.4 \%)，静注では全例に移行が証明される・テトラサイク リンは筇注ならびに静注とも全例に移行が証明される， クロラムフェニコルも全例に移行が談められる・エリス ロマイシンでは明らかに移行の認められるのは䈤注 25 例中 5 例 $(20 \%)$ ，静注 38 例中 10 例 $(26.3 \%)$ あり，
痕跡様のものも含めると筋注 25 例中 12 例，(48:0\%)

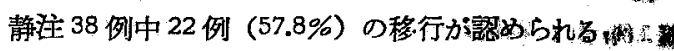

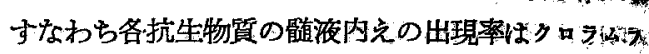

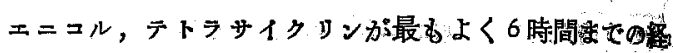

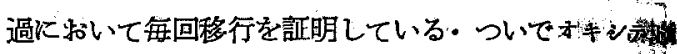
ラサイタリンタロルテトラサイタリンストレフド イシン，メリスロマイシン，ペニシリンの順である,

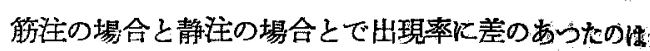
クロルテトラサイクリン，ォギテトラサイタリタに著 明であり，エリスロマイシン，ストレプトマイシンに洋 僅か汇認められ，その他の抗生物質では認めら机い。

また䯣液内移行の㭙閂的関係についてみると，吅 ムフェニニルとテトラサイクリンは6洔間後に和ても 相当の移行を示しているが，その他の抗生物質で3時 間後までは移行を認める場合壮多いが，6時間後では痕 跡様となるかあるいは移行の証明されないことが多い。

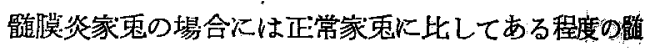
液内移行の堌加は認められるが，これを有効惯磨の虑か，

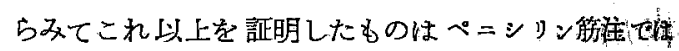
57 例中 9 例 $(15.7 \%)$, 静注 66 例中 10 例 $(15.1 \%)$, , トレプトマイシン解注 38 例中 4 例 $(10.5 \%)$, 静注 30 例: 中6 例 (20\%)，クロルテトラサイクリン筋注 16 例中? 例 $(43.7 \%)$ ，静注 28 例中 18 例 $(64.3 \%)$ ，才キシ ラサイクリン筋注 25 例中 20 例 (80\%), 静注 29 例中20

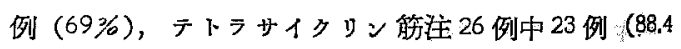
$\%)$, 静注 31 例中 28 例 $(90.3 \%) ， タ ロ ラ 4 フ エ=7 / N$ では笳注でも静注でも100\%に有效澧度が証明される。 エリスロマイシンでは筋注 37 例中9 例 (24.3\%), 静拄 33 例中 8 例 (24.2\%) 飞有效濃度の移行が認められる。

すなわち，クロラムフェニコルとテトラサイクリン采 統のものは 80〜100\% の有效濃度移行率があり，その他 の抗生物質では $20 \%$ 前後であり，有效湭度移行率の点 からみればクロシムフエニニルが最もよく，ついでテト ラサイリリンオキシテトフサイクリン，クロルテト サイタリン，エリスロマイシン，ストレブトマイシ ペニシリンの順である.

またクロラムフェニコル，テトラ正イクリンは6時間， 後でる有效量を保持しているが，その他の抗生物算でる 洔間後には有效量の移行をみない場合が多い.したがう てクロラムフェニュルやテトラサイクリン秀統のいのは 6 時間毎の注射で臨床的効果を期待できるが，その侇の 抗生物質では骮液内移行の時間が短く，点商静注の如き 万法で血中濃度を絶えず高濃度に維持したとしても䯠脽 


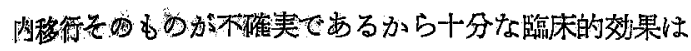
期待乙難い之考古られる。

\section{V. 結 論}

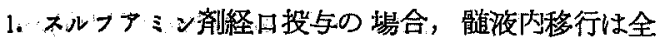
例以認められ，最高值を示すのはドミアン12時間で移 行率75\%，サイアジン 8 時間で移行率 $32 \%$ 、スプロナ ール4 時間で移行率 $40.5 \%$ である。

2. スルフアミン剮静注の場合に最高值を示すのはい ずれもる時間で，移行率はドミアン50\%，サイアジン $29.1 \%$ ，スプロナール 49.2\%である.

3、同特に採取した大槽ならびに 腰槽内顝液濃度には 大崟なくその消長る極めて類似している。

4: 最すよく移行するのはドミアンが最高で，次でス プロナール，サイアジンの順である。

5. スルフヌミン用静注の 場合には経口投与によるよ りる速か移行しているが，移行量，髄液内消長は極め て類似している・したがつて最初の急を要する場合には 静注が優れているが，その後の髄液内有效濃度を保つた め炏泩服によるのが実際にかなつている。

6. 正常家鬼に抗生物質を 投与した場合， ペニシリン 住筋注でも静注でも艏液内移行を証明し得ない. その 他の抗生物質では移行を証明する場合るあり，しない場 合るある・その移行を証明する割合はクロラムフェニニ ルとテトラサイクリンが最もよく100\%に移行が諗めら れる・次でオキシテトラサイクリン（筋注 $67.7 \%$ ，静注 $92.0 \%)$ ，クロルテトラサイクリン（能注 $12.1 \%$ ，静注
65.1\%)，ストレプトマイシン（筋注 $22.4 \%$ ，每注 26.3 \%)，エリスロマイシン(筋注 20.0\%，静注 $26.3 \%$ ），ベ ニシリンの順である。

7. 正常家鬼の堭合，クロラムフェニニルとテトジ ヘクリンは6恃閒後でる相当の移行を示しているが，そ の他の抗生物質では 3 時間後季でに移行を諗めることも あるが，6時間後では痕跡様となるかあるいは移行が認 められない。

8. 䨋脱炎家鬼の場合，有效濃度の移行が認められる 割合沬，クロラムフエニコルが最むよく100\%に証明

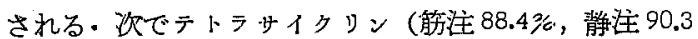
\%)，オキシテトラサイクリン(朌注 80\%，静注 69\%)， クロルテトラサイタリン（筋注 $43.7 \%$ ，静注 $64.7 \%$ ）， エリスロマイシン（筋注 $24.3 \% ，$ 静注 $24.2 \%$ ），ストレ プトマイシン（筫注 $10.5 \%$ ，静注 $20 \%$ ），ペニシリン (筋注 $15.7 \%$ ，静注 $15.1 \%$ ) の順である.

9. クロラムフエニコル，テトラサイタリンは6将間 後でも有効量を保持しているが，その他の抗生物質では 3 時間後には有效量の移行をみない場合が多い。

10. クロラムフェニニル，テトラサイクリン，キシ テトラサイクリンは 6 時間毎の注射で臨床的效果を期待 できるが，その他の抗生物質では骮液内移行の時間が短 く，かつ移行量が少く，末心移行の頻度乏のるのが不碳 実であるから十分な臨床的效果は期待し難いるのと考元 られる。

第 2 篇 スルフアミン剤ならびに抗生物翼の䯣膜剌戟

に関する実験的研究
目次
I 緒宮
』実験方法
III实験成綪
A 体溫および一般状题にお゙よぼす影腤
B 血液山血球数におよ添す影響

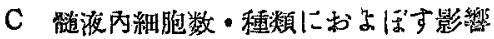

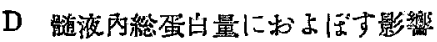

V 綛括ならびに溇挍

$V$ 絬論

\section{I. 緒言}

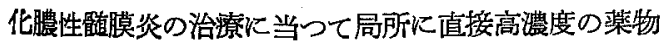

を作用させる意味では䯣腔内注射法は優れだ方法である が，時としていろいろの不快な副作用が 報告されてい

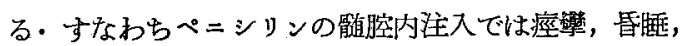

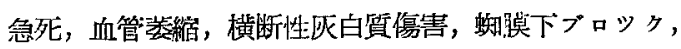

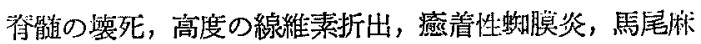
瘟, 神経根炎等の激しいるのから，1時的の頭痛，全射

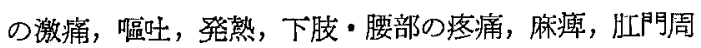
囲括約筋の弛緩，知敩過敏，発圈等の軽度のものまでが 㭙として見れる・ストレプトマイシンの骫腔内注入によ

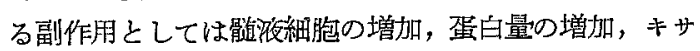
ントクロミー，線䊒素制物質の折出，軟㿠の溷濁，血管 の充盈, 液压の増加, 知網膜下出血, 発熱, 矓量, 耳 


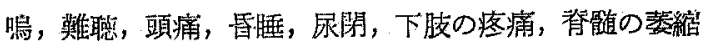
等が報告されている・

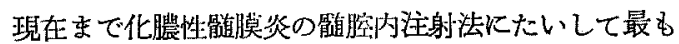
多く触いられているのはぺニシリンであるが，最近ぺニ シリンの感受性菌が高度の耐性を蒦得するようになり， ペニシリンのみでは波足できない嚗合が多く，全身的に は他の抗生物質ならびに高級スルファミン郕が応用され ているので，これらの新しい楽成が䯣腔内注入し得る か否かは研究さるべさ重要な問題である・

このために基礎的研究としてなづ菂剂の䯣膜にたいす る制㦸性について梌棓されている・この問題については 国に金野孝授によつて取りあげられ，トリパフラビン， 引ロトロビン，リパノール，エレシトラルゴール等 20

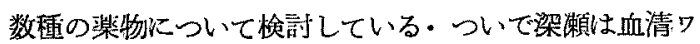
クヂンおよびュタチダンについて，林は種ふなるガス体 について䯠膜刺㦸性を検行した・化学製剂おるよび抗生物 質については三林がレギオン，テラポール，トリア， ン, 将ル゙ールについて，鹿野がペニシリン，ストレプ トマイシンの䯣膜刺踔について夷験的に研究しているに すぎない。これらの成續についてみると，古典的薬郕に おいて金野教授は 20 数雷の薬物中より䯕腔内に用い得 るものはウロトロピン唯 1 種類だけを挙げ，三林はズル ファミン成では市販品をいくら稀釈してもな法䯣腔内に 用いることは后険であると発表しており，鹿野はぺニシ リンで䯣膜刺钱を少く求めるならば500 単位以下にする のがよいだろうと言つて拈り，ストレプトマイシンでは さらに刺㦸が強いとのべている。

以上の諸氏は体温，一般状態，血液白血球数，䯣液内 細胞ならびに総蛋白量の変動によつて䯣䑏刺㦸程度を推 祭している・私もこれにならつて，スルフアミン㓮とし てドミアン，サイアジン，スブロナール，抗生物質とし てペニシリン,ストレプトマイシン，クロールテトラサ イタリン(オーレオマイシン)，オキシテトラサイクり ン (テラマイシン), テトシサイクリン（アクロマイシ ン), クロシムフエニニル(クロロマイセチン), エリス ロマイシンの䯣膜刺㦸について観察した・

\section{II. 実 験 方 法}

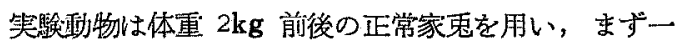
般状態を倠祭し，体温测定，採血についで後頭下第束肺によ つて随㴼 $0.4 \mathrm{cc}$ を採取し，穿刺針をそのまつにして扣い て，その針から直らに楽剂を注大寸る・注大直後より 24 時間に亘つて一般状態を観察し，体温は肛門内 $6 \mathrm{~cm}$ の梁さに体温計を㨂入し，注大直前，直後，30 分，1時
間，3 時間，6時間，24 時間後の7 回測定，血没像は住 入正前，3時間，6㭙間， 24 時間後の 4 回，主として白 血球数（Thome-Zeiss 氏計算室による）を計算した。 䯣液の検查は注入直前，3時間，6時間，24時間倦に絊 胞数 (Fucks-Rosenthal 氏計算室による). 細胞重颣 (Scécsi 氏染色法による)，総蛋白量（Brandberg.Pfandler 氏法による）を測定した。

注入する液量によつて刺战の程度が異なるから溶媒は 一律に $0.2 \mathrm{cc}$ 生理的食監水とし，注射にあたつては往射 㨽内で䯣液とよく混和しながらさかめて徐々に注入し た。

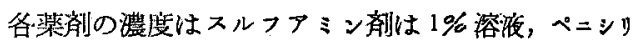
ンは 200 単位，その优の抗生物質は $0.5 \mathrm{mg}$ である。

\section{III. 実験成績}

\section{A 体温括よび一般状態}

1. スルファミン郕(第 11 表，第4図）

(1) $ト * ミ ア ン$

1 例は注入後 1 時間まで体温上昇を示し，ついで少し く下降し再び上笔して6時間後に最高を示した：他の例 は最初体温の下降があり，ついで上昇して6 時間後に最 高值を示し 24 特間後には注入前の值に近くなるか，そ れよりや」下降した・体温上昇最高 $1^{\circ} \mathrm{C}$,下降最低一 $0.6^{\circ} \mathrm{C}$ である。
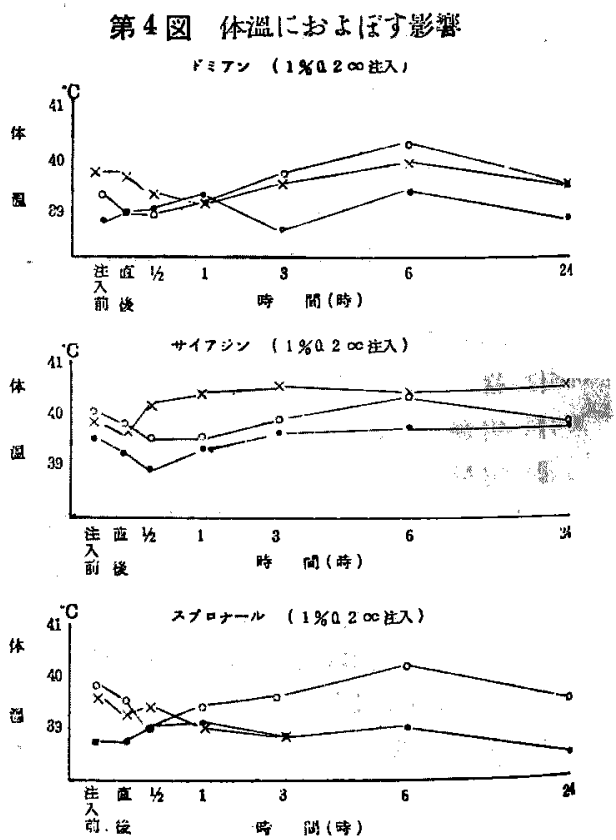


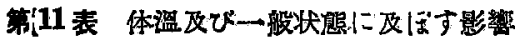

\begin{tabular}{|c|c|c|c|c|c|c|c|c|c|c|}
\hline & & & & 体 & & & 17 & C) & & \\
\hline & 妌 & 西 & 注入住 & 国 & 80 分 & 12時阅 & B时间 & 醏问? & 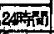 & 一粈状目交化 \\
\hline & & 1 & 826 & 388 & 889 & 892 & 88.5 & a9 8 & 987 & 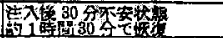 \\
\hline & $5 \div 7 \%$ & 2 & 892 & $88-8$ & 388 & 390 & 36 & 402 & 394 & 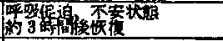 \\
\hline & & g. & 296 & 396 & 59. 2 & 390 & 894 & 398 & 394 & . \\
\hline & サイナシン & 4 & 895 & 392 & 389 & Ba 3 & 26 & 37 & 997 & 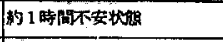 \\
\hline & & 5 & 400 & 898 & 295 & 895 & an 9 & 403 & 298 & 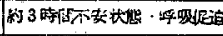 \\
\hline & $1 \% 0200$ & 6 & 398 & 396 & 402 & $\Delta 04$ & 40.5 & 404 & 40.5 & 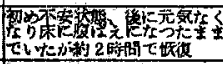 \\
\hline & スフォナー & 7 & 38.7 & 387 & 20.0 & 391 & 868 & $3 a 0$ & 385 & 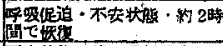 \\
\hline & & 8 & 328 & 395 & 290 & 324 & 396 & 402 & 2as 5 & 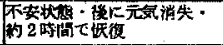 \\
\hline & 180.200 & 12 & 69 & $39 \mathrm{~s}$ & 394 & 390 & 388 & & & 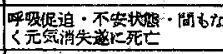 \\
\hline & & 15 & 884 & $\mathrm{AZB}$ & 368 & 387 & 389 & 384 & 826 & \\
\hline & & 16 & .280 & 37.7 & 324 & 378 & 572 & 307 & 329 & 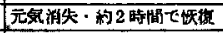 \\
\hline & 0.200 & 20) & 367 & 320 & 378 & 326 & 379 & 385 & 327 & \\
\hline & & 21 & 386 & $28 \mathrm{~B}$ & 389 & 353 & 2. 5 & 286 & 886 & \\
\hline & & 28 & 58 \& & 323 & 32.? & $a 24$ & 982 & 3.2 & $3 B_{0}$ & 元気消失 \\
\hline & $05^{\mathbb{D S}} / 02 \infty$ & 24 & 382 & 877 & 372 & 37.0 & 38.8 & 887 & 326 & 元気消失 \\
\hline & 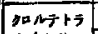 & 26 & 400 & 400 & 400 & 39.5 & 401 & 40.3 & 21 & 元目消失 \\
\hline & & 20 & 398 & a 1 & 38.5 & 389 & 397 & 400 & 400 & 䒔氛消失 \\
\hline & $05^{38} / 02 \infty$ & 20 & 398 & 400 & 408 & 402 & 4 2 & 40.6 & 327 & \\
\hline & & 31 & 897 & 397 & 400 & 405 & 408 & 42 & 392 & \\
\hline & & 32 & 394 & 390 & 891 & 39.5 & 403 & 408 & 89.7 & \\
\hline & $05^{\mathrm{ng} / \mathrm{az}} \mathrm{co}$ & 98 & 820 & 393 & 595 & 403 & 39.8 & 996 & 395 & \\
\hline & $5+5+1$ & 34 & 395 & 395 & 398 & $40 \mathrm{a}$ & 40.5 & 39.9 & 393 & \\
\hline & & 35 & 396 & 394 & 392 & 397 & 400 & 403 & 394 & \\
\hline & & 86 & 32 & 895 & 998 & 401 & 9 & 395 & 394 & \\
\hline & & 37 & 898 & 396 & 390 & 320 & 400 & 502 & 394 & 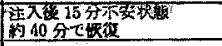 \\
\hline & & 38 & 394 & 396 & 400 & 39. 3 & 32 & $39 \mathrm{~B}$ & 40.1 & \\
\hline & & 39 & 391 & 891 & 394 & 395 & 415 & 407 & 392 & \\
\hline & & 40. & 400 & 400 & 398 & 395 & 401 & 405 & 391 & 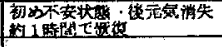 \\
\hline & & 41 & 295 & 89 3 & 393 & 89.5 & 297 & 395 & 391 & \\
\hline & & 42 & 39.2 & 590 & $\begin{array}{lll}88 & 4\end{array} \mid$ & 380 & 391 & 395 & 393 & 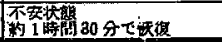 \\
\hline
\end{tabular}

一般症状生了例中 2 例飞見られ，注入後 30 分〜1 時 間で抙吸促迫，不安状熊がみられたが死亡例はない。

(2) サイアジン

2例は最初の 1 3 時間まで体温下降ありついで漸次 上昇し6時間で最高となり，1. 例はそのま 24 時間続 き，1例は 24 時間後にはや\下降した・他の例は往入 直後下降を示したが， 30 分後には上昇し 3 時間後最高 を示し，そのまつ糟溜した・最高上昇度 $0.7^{\circ} \mathrm{C}$, 最低下 降度 $-0.6^{\circ} \mathrm{C}$ である。

一般优態の変化は全例にみられ，2 例は不安状態を示 し，1例灶初め不安状熊，呼吸促迫し後元気がなくなり 床以腹ばえになつた霓つでいたが約 2 時間で恢復した。

(3) スプロナール

1例红最初より体温上昇し1-時間後偮高値を示し， 後多少の変動を示し 24 時間後には注入前より下降した。 他㵊初の 1 時間まで体温下降あり，そのうち 1 例性 6 嚇間後に 最高值を示したが，24時間後には再び下降し 代。他の!例は次第に体温が下降してりき，3時間 20

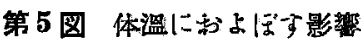
抗生物筫 $0.5 \mathrm{mg} / 0.2 \mathrm{ec}$ 注入
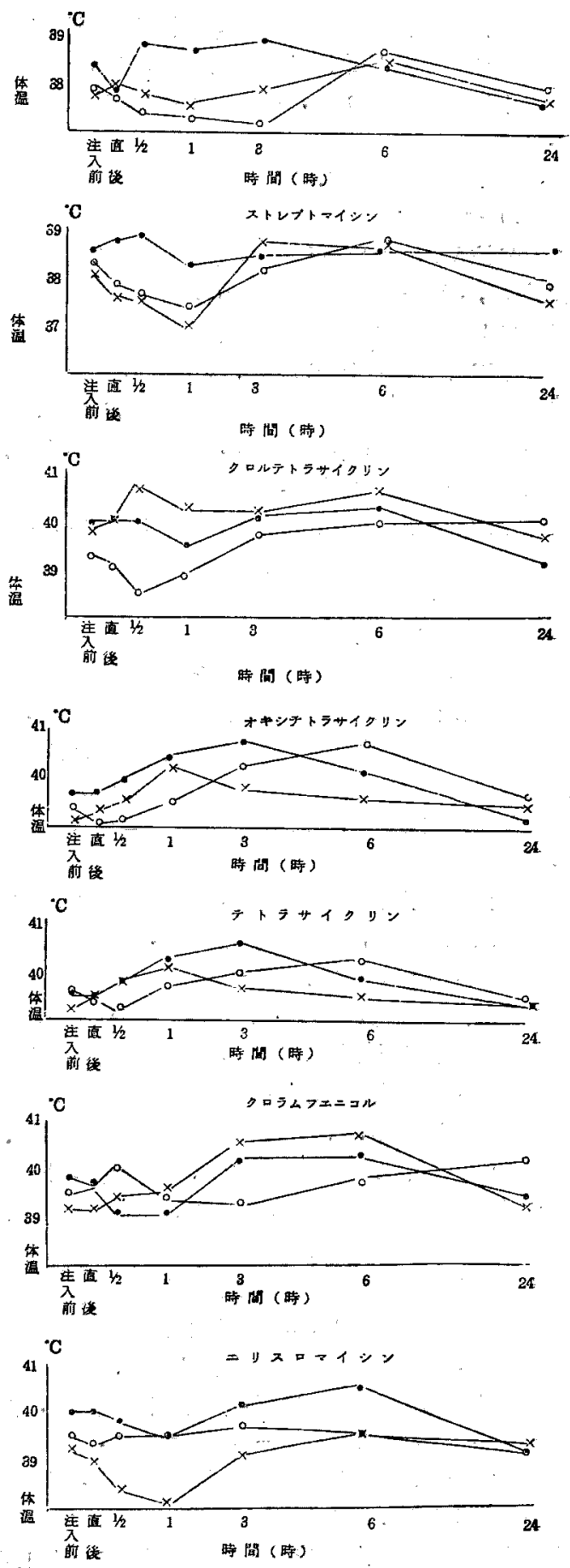
分ほどで死亡した・最高上昇度 $0.6^{\circ} \mathrm{C}$, 最低下降度 一 $0.8^{\circ} \mathrm{C}$ である.

一般状態の変化は全例にみられ，最初呼吸促迫，不安 状態を示したが間もなく元気がなくなり，1例は注入後 約 3 時間 20 分で死亡した，他の例は約 2 時間で恢復し t。

\section{2. 抗生物質 (第 11 表, 第 5 図)}

(1) ペニシリン

1 例は注入直後や」体温の下降を示したが間もなく上 年し始め，30 分〜3 時間まで䅝溜し，3時間後次第に下 降して 24 時間後には注入前よりや」下降していた・他 の例は初めや>変動を示したが，1 時間〜3時間までや や下降し以後次第に上异して 6 時間後最高となり，24 時間で殆んと゚注入前の值に戾つた・最高上算度 $0.8^{\circ} \mathrm{C}$, 最低下降度 $-0.8^{\circ} \mathrm{C}$ である・

一般状態の变化を示したるのは 3 例中 1 例あり，3 時 間後から元気がなくなり横臥していたが 24 時間後には 恢復していた。

(2) ストレプトマイシン

2 例化いて最初の 1 時間まで下降し後上昇 3 6 時 間で最高となり 24 時間後には注入前より下降した・1 例は最初より上昇し始め 30 分で最高となり1時間後に や」下降し，その後は注入前に 戻りそのま 24 時間持 綕した・最高上梨度 $0.6^{\circ} \mathrm{C}$, 最低下降度 $-1.0^{\circ} \mathrm{C}$ であ る.

一般状態の変化を示したものは 3 例中 2 例あり，や」 元気がなくなつたが，間もなく恢復した・

(3) クロルテトラサイクリン

1 例は最初から体温上算あり，6時間で最高を示し 24 時間で殆えで注入前の值に杘つた・他の 2 例は最初体温 の下降あり 3 時間後に上昇し 6 時間で最高となり，1 例 は 24 時間後まで稽溜し，1 例は 24 時間後に低下した。

一般状態の变化は 3 例中 2 例あり，注入後 10 分で不 安状態を示していたが間もなく恢復し，軽微であつた。

(4)オキシテトラサイクリン

1 例は注入後体温下降を示したが 1 時間後より上昇し 始め 6 時間で最高を示し，24 時間ではほぼ注入前に 戾 つた・他の 2 例は注入後次第に体温上算し，1 3 時間 で最高值を示し 24 時間後には注入前近くに戻つた・最 高上昇度 $1.4^{\circ} \mathrm{C}$, 最低下降度 $-0.5^{\circ} \mathrm{C}$ である。

一般状態の変化を呈したものは認められない。

(5)テトラサイタリン

1 例は最初体温低下があつたが 1 時間後から上昇し6
時間で最高を示し， 24 時間後には注入前の値近くにる どつた・他の 2 例は最初から上昇し始め1〜3 時間で最 高值を示し 24 時間後には注入前の值近くに戻つた。最 高上昇度 $1.1^{\circ} \mathrm{C}$, 最低下降度 $-0.4^{\circ} \mathrm{C}$ である.

一般状態の変化を呈したものは認められない。

(6) クロラムフニニ=ル

最初体温低下し後上昇して6 時間後に最高を示すも の, 最初体温上䒜乙 1 3 時間後に 低下し6時間加再 び上昇して 24 時間後に最高を示すもの，最初から体温 上昇し， 6 時間後に最高を示し，24時間後炷入前近〈 に庈るるのがある・最高上算度 $1.6^{\circ} \mathrm{C}$, 最低下降度 $0.8^{\circ} \mathrm{C}$ である・

一般状態の変化を 呈したもの 1 例あり，注入後 15 分 で不安状態を示したが約 40 分程で恢復した・

(7) エリスロマイシン

全例最初の 1 時間まで体温の低下があり，次で昇 し， 1 例は 3 時間後，他は 6 時間後に 最高値を示し，24 時間後では1例は注入前近くに戻つたが优の 2 例准体温 の低下を示している・最高上梨度 $0.5^{\circ} \mathrm{C}$, 最低下降度一 $1.2^{\circ} \mathrm{C}$ である・

一般状熊の变化を呈したものは3 例中 2 例あり，注入 後 5 分程て興鹤状態を示し，約 30 分後には元気がなく なり横卧していたが1 時間半位で恢復した。

\section{小}

体温におよぽす影響の一般的傾向として最初体温が低 下し，3〜6時間目頃に上昇し 24 時間後には注入前の体 温に近つくか，それより低目になつている場合が桝い. しかし最初から体温上䒜しているもの，途中て低下を示 するの，24時間後でる上昇あるいは低下を示するの ど色々で一定はしていない。

しかし体温の变動は各例ともに著明ではなく $1^{\circ} \mathrm{C}$ 以 上の変動を示したものはストレプトマイシン 1 時間後の $-1.2^{\circ} \mathrm{C}$, オキシテトラサイクリン 3 時間後の $+1.1^{\circ} \mathrm{C}$, 6 時間後の $+1.4^{\circ} \mathrm{C}, 1$ 時間後の $+1.3^{\circ} \mathrm{C}, \overline{テ ト ラ サ イ ク ~}$ ワン 3 時間後の $+1.1{ }^{\circ} \mathrm{C}$, クロフムフェニュル3時間鯫 の $+1.4^{\circ} \mathrm{C}, 6$ 時間後の $+1.6^{\circ} \mathrm{C}$; エyスロマイシタ 1 時間後の $-1.2^{\circ} \mathrm{C}$ だけで, その㴗かは $\pm 0.5^{\circ} \mathrm{C}$ 前後の 変動である・いつれにしてる経過中に一度は体温の上型 を示しているが, ススプロナール注入による死亡例て杜次 第に体温が下降し，ついに上梨することなく死至うて Wる:

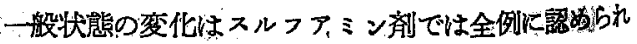
相当強くスプロナールで住1例死亡している・抗生物 
買ですある程度の一般状態の変化は呈するが，スルフフ ミン用汪と激しくなく，ことにサィクリン系統のもので は沿んど認められず，ペニシリン1例；ストレプトマイ ンン2例，クロラムフェニニル1例，エリスロマイシン 2例傜められる・このらちではエリスロマイシンによ るむのが最も強い一般状態の変化を呈した・体温变動の いちら゙るしいもの，とくに体温低下の甚しいるのに一般 犾熊の变化の強いものが多く認められる。

B. 血液白血球数におよぼす影響

1. スルフアミン㓮（第12表，第6図）

(1) ドミアン

全例白血球減少を前駆しており，6時間で最高值を示 し， 24 時間後に注入前の值に近づくが，2 例はな括相当 の增加を示している・最高堌加数の平均は3866である。

(2) サイアジン

全例とる 3 時間では相当の白血球減少を示し，6時間 ては最高の増加を示し 24 時間でるな海増加が認められ る・最高增加数 6733 である。

(3) スプロナール

全例著明な白血球隇少を前駆して和り，6時間後にて 高度の 白血球堌加をきたし 24 時間後にも相当度の堌加 を示している・最高堌加の平均は8866である。

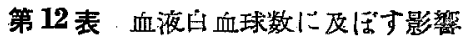

\begin{tabular}{|c|c|c|c|c|c|c|}
\hline \multirow{2}{*}{\multicolumn{2}{|c|}{ 乘 }} & \multicolumn{4}{|c|}{ 㚗血，知 } & \multirow{2}{*}{ 加芸 } \\
\hline & & 注入荫 & 3 時 & 6 時少 & 24 時用 & \\
\hline \multirow{3}{*}{$\begin{array}{l}\pi \\
\Delta\end{array}$} & \multirow{3}{*}{$r \quad z \quad 7$} & 3300 & 8900 & 13500 & 9500 & 1.45 \\
\hline & & 10300 & 9600 & 14,800 & 11,600 & 138 \\
\hline & & 9800 & 9200 & 13200 & 10.700 & 184 \\
\hline$>$ & \multirow{3}{*}{$\begin{array}{llll} & 1 & 7 & \%\end{array}$} & 9200 & 8600 & 16.500 & 10,200 & 1.79 \\
\hline \multirow{2}{*}{$\begin{array}{l}7 \\
\vdots\end{array}$} & & 9600 & 8900 & 25500 & 10800 & 1.61 \\
\hline & & 9800 & 7900 & 16. 800 & 13500 & 1.71 \\
\hline$\div$ & \multirow{3}{*}{$\pi>=t-x$} & 8600 & $\zeta 400$ & 18200 & 12600 & 211 \\
\hline \multirow[t]{2}{*}{ 刺 } & & 9800 & 8600 & 13800 & 11.800 & 2.81 \\
\hline & & B 400 & 7500 & 17400 & 13500 & 207 \\
\hline \multirow{8}{*}{ 沉 } & \multirow{3}{*}{$\dot{*}=\ddot{\nu} \nu$} & 8.000 & 3300 & 10100 & 9800 & 126 \\
\hline & & 8900 & 9900 & 11,000 & 9000 & 128 \\
\hline & & 9300 & 3800 & 10500 . & 9.500 & 112 \\
\hline & \multirow{3}{*}{ ストレフトマインン } & 8000 & 7800 & $9400^{\circ}$ & 10600 & 18 \\
\hline & & $\$ 200$ & 8.400 & 10100 & 9500 & 1. 28 \\
\hline & & 8700 & 2000 & 12,000 & 9800 & L. 37 \\
\hline & \multirow{3}{*}{ のロルテトラサイクリン } & 8200 & 9.100 & 12,000 & 9600 & 146 \\
\hline & & 7400 & 7600 & 9,400 & 9000 & 1. 27 \\
\hline \multirow[t]{3}{*}{ 生 } & & 3200 & 6,800 & 10600 & 11,009 & 1.62 \\
\hline & \multirow{3}{*}{ オキシテトラサイフリン } & 8.200 & 8200 & 10000 & 8400 & 121 \\
\hline & & 2200 & 7700 & 11.000 & 8000 & 152 \\
\hline \multirow{4}{*}{ 要 } & & 6.700 & 8.200 & 10400 & 7400 & 155 \\
\hline & \multirow{3}{*}{$7+5 * 1,0=$} & 8300 & 9600 & 10.300 & 8000 & 2.24 \\
\hline & & 9500 & 9800 & 11.100 & 10200 & 116 \\
\hline & & 8700 & 8900 & 19400 & 9,800 & $\mathrm{~L} 19$ \\
\hline \multirow[t]{6}{*}{$\pi$} & \multirow{3}{*}{ クேA エ = } & 14,460 & 19300 & 12100 & 12200 & 20 \\
\hline & & 9000 & 9200 & 11,600 & 8700 & 2.27 \\
\hline & & 8800 & 8,000 & 11,200 & 9,000 & 1.27 \\
\hline & \multirow{3}{*}{ 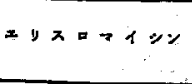 } & 9000 & 8600 & 7600 & 8200 & 108 \\
\hline & & $8 B 00$ & 8600 & 8600 & 8200 & 108 \\
\hline & & 8000 & 8100 & 2400 & 2700 & 1.17 \\
\hline
\end{tabular}
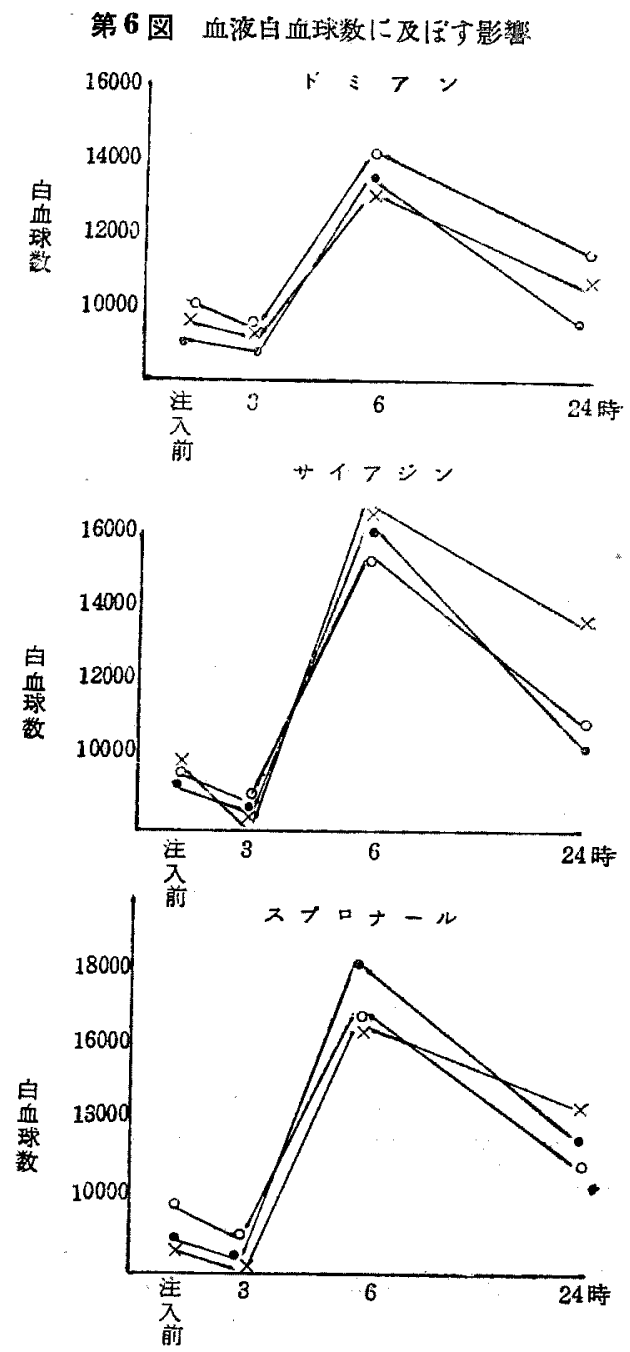

2. 抗生物質（第 12 表，第 7 図）

(1) ペニシリン

全例とも最初より增加し，の6時間後に最高に達し 24 時間後には注入前に 戻るか少しく増加の程度で ある・最高増加数の平均は 1650 である・

(2) ストレプトマイシン

1 例は 3 時間をで娍少し，6時間では増加を示し て㧍り，24時間で最高值を示している・他の 2 例 は白血球の減少汭な，6時間で最高を示して和り 24 時間でる著明な増加を!呈している・最高堌加数 の平均は 2633 である。 
第7 图、白血球数に及ぼす影集
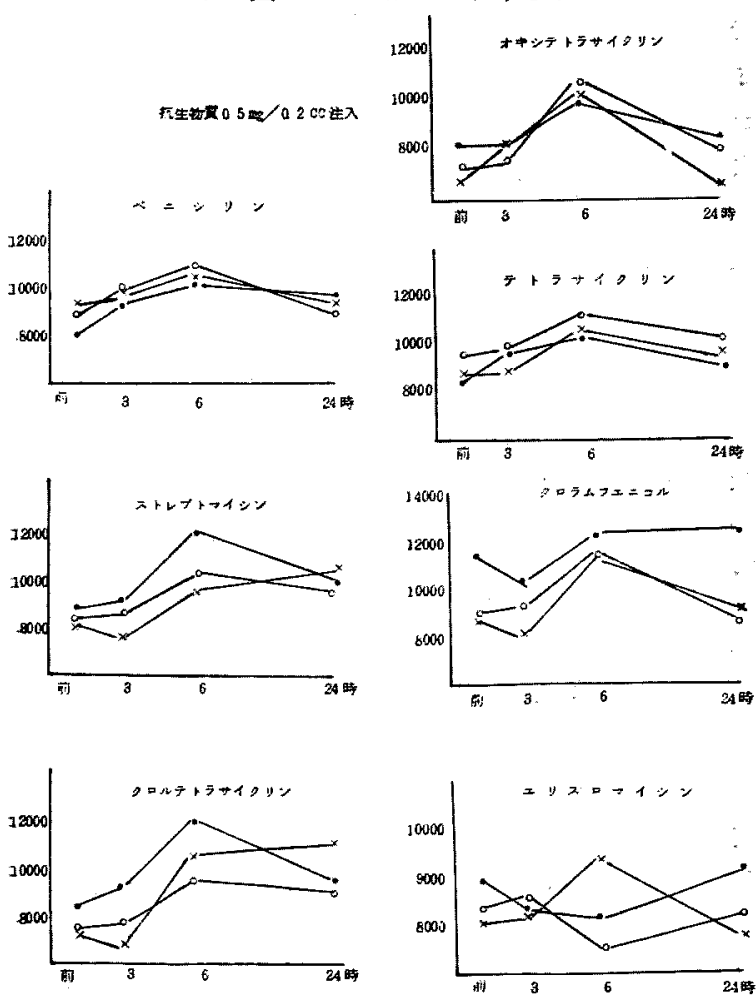

時間後には堌加し，夫た6時間，24時間熶高值 を示している・最高増加数の平均は 1900 である.

(7) エリスロマイシン

1 例は3 時間, 6時間ては白血球減少を示し，24 時間で少しく増加している・他の 2 例は3 時間で 増加しているが，6時間では1例は減少し，1例は 最高の増加を示し， 24 時間では其に減少している。 最高増加数の平均は 600 である・

$$
\text { 小 括 }
$$
6 時間後には著明な白血球増加をきたし，24時間後 にもな和相当の増加を示している・最高增加数の平 均值はスプロナールが最高で，サィアジンドミア ンの順である.

抗生物質では最初から増加を示寸るのが多いが， 減少应を前整とする場合るあり，とくにクロラムフ エニニルに著明で, ストレプトマイシン,クロルテ トラサイクリン，エリ゙スロマイシンでる各は1例ふ つ楒められる・しかし, 減少と増加の度合はスルフ アミン剂に比較すれば甚しくはない.またェリスロ アイシンでは白血球減少症となる傾向が多く，最高 増加の場合にも 3 時間, 6 時間, 24 時間後と一定し

第 13 表 䯚液內細胞数・種類に及ぼす影箱
(3) クロルテトラサイクリン

2 例は最初から増加し，6時間で最高を示し 24 時 間後でも相当の増加がある・1例は最初白血球減少 し，後次第に増加し，24 時間後に最高を示してい る・最高增加数の平均は 3200 である・

(4) オキシテトラサイクリン

1 例は 3 時間まで变動なく，6時間で最高を示し， 24 時間でほら゙注入前の值に 戻つた。他の 2 例は最 初から増加し，6時間で最高値となり，24時間でる や土增加の程度である・最高增加数の平均は 3033 である・

(5) デトラサイクリン

全例とも最初から白血球数の増加があり，6時間 で最高值を示し，24時間でもや」増加している。 最高増加数の平均は1700である。

(6) クロラムフェニコル

1 例は始め白血球の増加があり，6時間で最高值 を示し，24時間では注入前より減少している・他 の2 例では 3 時間後では白血球数の娍少があり，6

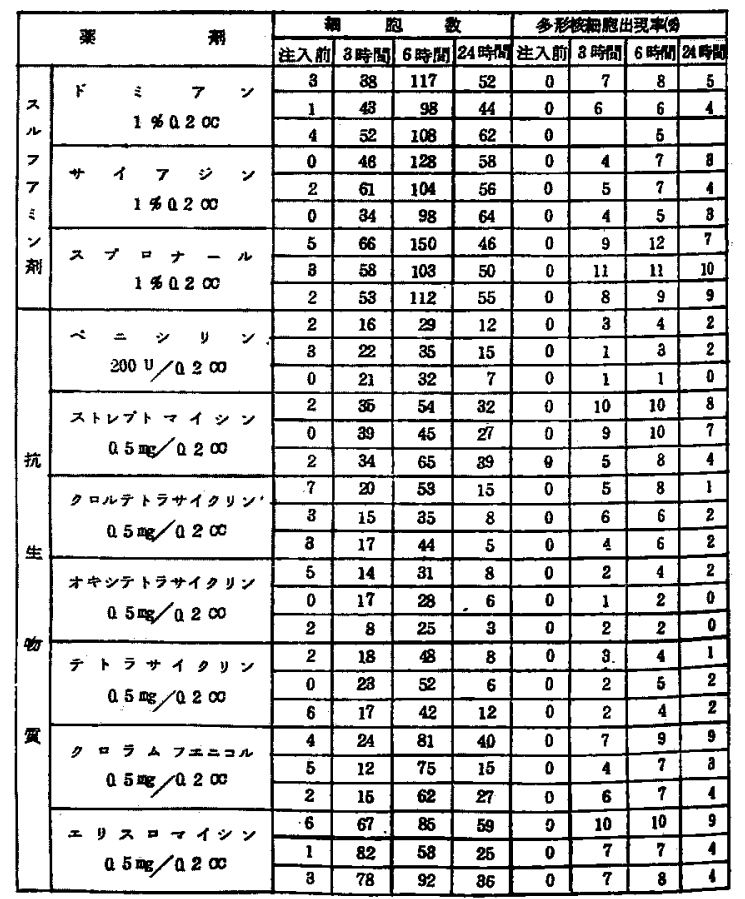


ていない、最高増加の時期が24 時間のものはクロルテ トラサイクリン，ストレプトマイシン，クロラムフェニ ュル各タ.1例あるが，多くの場合には6 時間に最高増 加を示している・24時間では多くの場合注射前より増 加の程度にあるが，クロフムフェニコル，エリスロマイ シンでは減少を示すむのが多い。

最高堌加数の平均では，クロルテトラサイタリンが最 高で，オキシテトラサイクリン，ストレプトマイシン， クロラムフエニコル, テトラサイクリンペニシリン， エリスロマイシンの順である・

\section{C. 髄液内細胞数・種颣に括よぼす影響}

1.スルフフミン剂（第 13 表，第 8 図）

トミフン，サイアジン，スプロナールの各例ともに3 侍間で相当な細胞数の増加が認められ，6時間で最高の 稩胞堌加を示し，24時間ですな和著明な細胞増加があ る・最高増加を示す6時間に执ける細胞数の平均はスプ

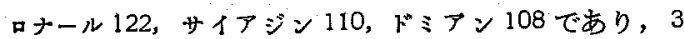
特間並に 24 時間では 50 前後の細胞増加である・細胞の
種類では注入前には全部単檬緛胞であるが3時間ではド ミアンが $6 \%$ ，サ1アジン4〜5\%，スプロナール11\% 前後に㧤いて多形核細胞が出現して括り，6時間では同 じ程度かあるいは少しく増加しており，24時間でもげ ミアン4〜5\%，サイアジン 3〜4\%，スブロナール $8 \%$ 前後に出現している・いづれにしてる6時間で最高とな

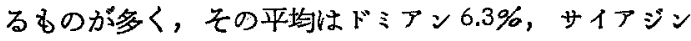
$6.3 \%$ ，スプロナール $10.6 \%$ である.

2. 抗生物筫 $(3$ 表, 第 9 図)

各抗生物質ともにサルフア剂と同様に，6時間で最高 堌加を示している・ペニシリンでは 3 時間の平均が 19 で6時間の最高増加数の平均が 32 であり，24 時間では 11 である・多形核細胞も2\%前後に出現しているが，24 時間では諗められないるのるある・

ストレプトマイシンでは3時間で平均 36 の相当な增 加があり，6時間で55 の増加を示し，24時間後におい

第9图髄液內紐胞数に゙仅ぼす影響 抗生软筫 $0.5 \mathrm{mg} / 0.2 \mathrm{cc}$ 注入
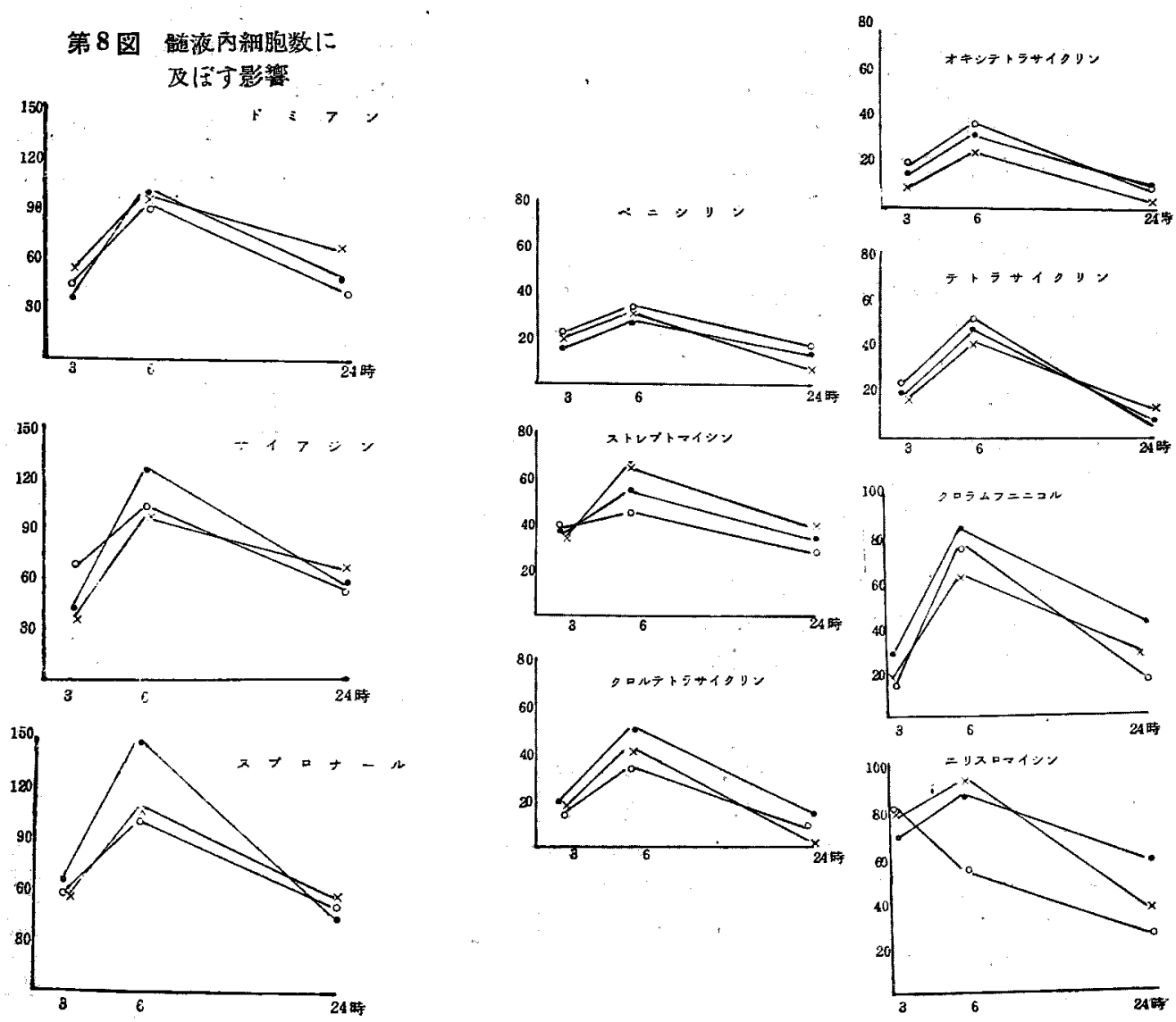
てむな和相当な堌加を示している・多形校細胞む3時間 から9\%前後に出現しており，24時間でも $6 \%$ 前後に 出現している。

クロルテトラサイクリンでは3 時間の平均が 17 で軽 度に增加して括り，6時閫では平均 44 之相当の增加を 示し，24 時間では平均 9 という程度の增加にまで恢復 している. 多形校細胞の出現率でる 3〜6時間では 5〜6 \%であるが，24時間では1〜2\%である・

オキシテトラサイクリンでは3 時間の細胞数平均か゚ 13 で，24時間では殆えどもとに杘り，最高値を示す6 時間でも 細胞数 28 である. 多形核細胞も2\%程度のも のが多く，3例中 2 例は 24 時間でその出現は認められ なからた。

テトラサイクリンでは 3 時間の縕胞数平均 17 ，6時間 47,24 時間9で堷明なるのはなく，また多形核細胞の出 現も $4 \%$ 前後で，24 時間では1〜2\%でむる.

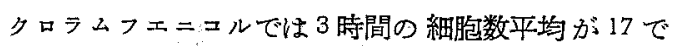
あまり著明ではないが，6時間では平均 73 の相当な堌 加を示し， 24 時間であ平均 27 といら増加数である.多 形核細胞も最初から $7.6 \%$ の出現をみ，1例では 24 時間 でもな物同じ程度に認められた・、

エリスロマイシンでは最初から著明な堌加があ り，6時間では 2 例中 1 例は 3 時間よりも減少した が，他の 2 例は更に增加し，平均77である. 24 時 間ではや減少したが，それでる平均は40である。 多形校細胞む3〜6時間では $8 \%$ 程度の 出現をみ， 24 時間ではや小減少したが，1例はなお 9\%の出現 率を示している・

\section{小 括}

スルフアミン削，抗生物質ともに最初から增加 し，6時間後に最高を示し，24時間後にもな和相当 増加しているものbあるが，注入前の值近くに底る ものもある・これは特にテトラサイクッン系㓍のも のに見られる・またェリスロマイシンの1例では3 時間で最高を示し後次第に減少してゆくものがあつ た・

細胞の 程颣では注入前には全部単核細胞である が，3时間上後には多形核細胞す出現し，この場合 にも6 時間で最高を ボすものが多いが，3時間と6 時間が同じ值をとるものもかなり認められる・更に 24 時間でも多形核細胞比現率方 6 時間のものと大 差ない場合が，スブロナール3 例中 2 例，クロラム フェニニル1例, エリスロマイシン1例に括いて認 められた・
最高の細胞数平均について比較してみると,スルファ ミン郕と抗生物筫では前者がはるかに多く，スルフフミ ン戍の5ちではスプロナールが最高で, サイアジン， ミアンの順である・抗生物質ではェリスロマイシンが最 高で, クロラムフエニニル,ストレプトマイシン, タト ラサイクリン, タロルテトラサイクリン, ペニシリン, オキシテトラサイクリンの順である.

多形核細胞の出現率についてみると;スルフアミン成 と抗生物質とでは大差は諗められない.出現率の小さい ものはペニシリン，ォキシテトラサイタリンで, テトラ サイクリンも著明ではない・昔の最高出現率を比較して みるとスルファミン郕ではスブロナール10.6\%で最高, ついでドアン，サイアジンはともに $6.3 \%$ である。抗 生物質ではストレブトマイシンが最高で $9.3 \%$ ，ついて エリスロマイシン $8.3 \%$ ，クロラムフェニコル7.6\%, , ロルテトラサイクリン 6.6\%，テトラサイクリン4.3\%, オキシテトンサイタリンおよび ペニシリン $2.6 \%$ の順で ある・

D. 髄液内総蛋白量の变動

1.スルフアミン剤(第 14 表, 第 10 図)

(1) $ト * \vdots>$

全例とも3 時間で蛋白量の増加を示し，そのらち2例

第 14 表 骾液總蛋白量に及ぼす影繁

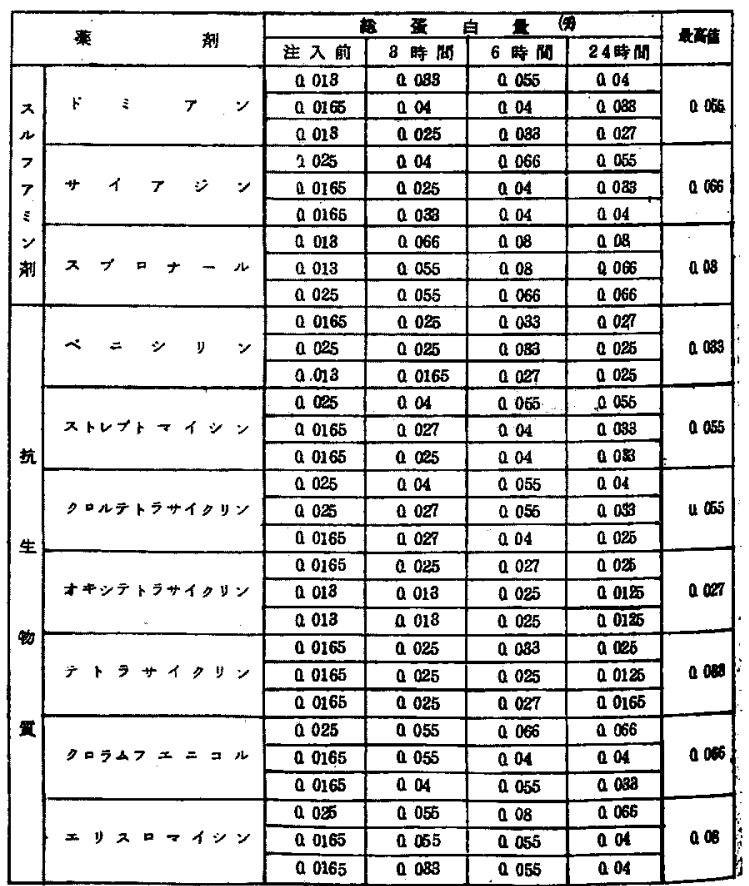




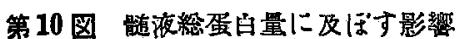
スルフフミン剂 $1 \% 0.2 \mathrm{cc}$ 注入
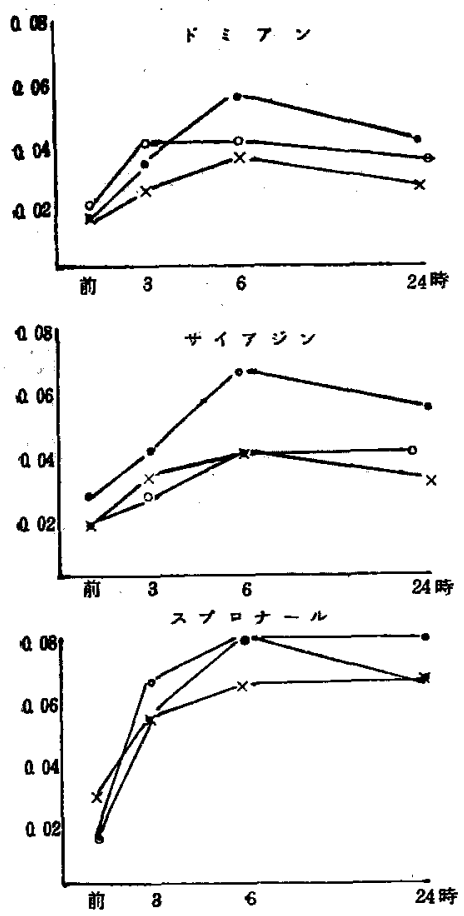

は6時間で更に増加して最高值を示し，24時間では3 時 間目の值に 戾るかそれよりや〉高い値を示した・1 例 は3 時間と6 時間後の 值は同して，24時間後にはや」 滅少したが，注入前の值に比べると相当の増加を示して いる: 最高紹蛋白量は $0.055 \%$ で，その平均は $0.043 \%$ でる。

(2) サチアジン

全例とる3時間目で蛋白量の普加があり，6時間目に 性更に堌加して最高值をとり，24時間では6 時間と同 こもの1例で，他の 2 例ではや〉減少したが3時間目の むのよりは高い値を示している・最高総蛋白量は 0.066 \%でその平均は $0.048 \%$ である。

(3) スプロナール

全例 3 時間で相当な蛋白量の増加があり，6時間では 更に堌加して最高値を示し，そのうち 2 例は 24 時間後 る同じ值を示し，他のI例は少しく減少はしたがな和著 明な蛋白増加を示している・最高総蛋白量は $0.08 \%$ で, その平均は $0.075 \%$ である。

2. 㧤生物質（第 14 表，第 11 図）

(1) ペニシ ソン.

3 時間目では1例に和いて極く僅か心 増加を示してお

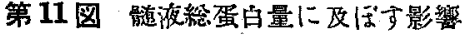
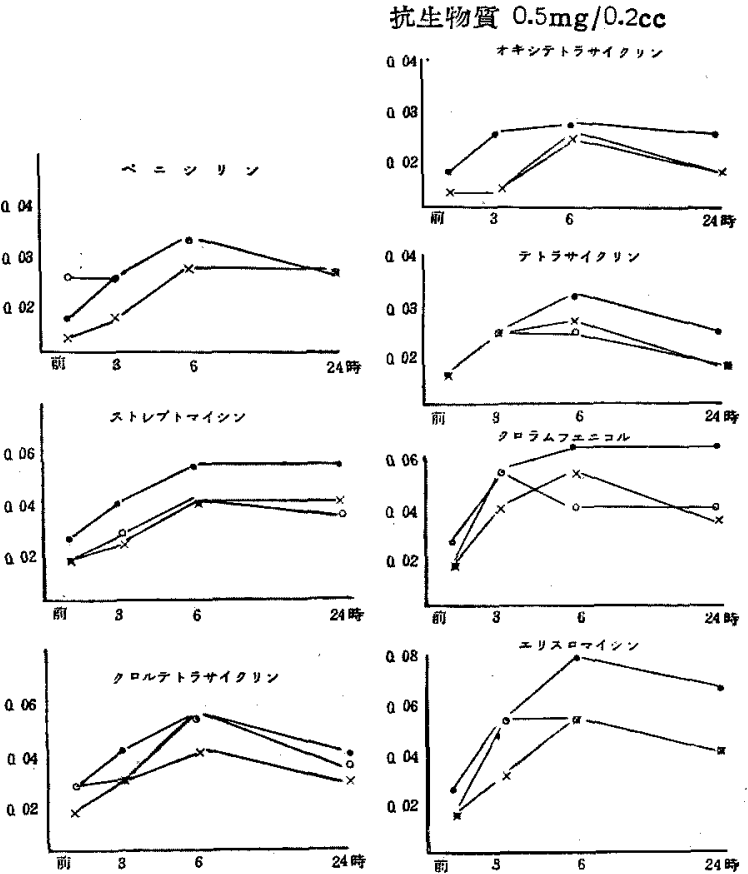

り，他の 2 例では注入前の 值とほとんど変りがない６ 時間では全例とも蛋白量の増加を示すがあまり著明なる のはない. 24 時間では 2 例が 3 時間ならびに注入前の 值に戾つているが，1 例では 6 時間目の值とほとんど変 りがない，最高総蛋白量は $0.033 \%$ でその平均は 0.031 \%である・

(2) ストレブトマイシン

注入前に比輘すれば全例之も3 時間目に軽度の蛋白增 加があり，6時間では更に増加して最高値をとり，1 例 では24時間後でも同じ值を示して牱り，他の 2 例はや や減少はしているが3時間目のるのよりは高い値を示し ている・最高総蛋白量は $0.055 \%$ でその平均は $0.045 \%$ である・

(3) クロルトトラサイクリン

1 例は3 時間目でや〉蛋白増加しているが，他の 2 例 は注入前と大差なく，6時間では全例と西蛋白増加して 最高値をとり， 24 時間後には殆んど 3 時間目の倠近く

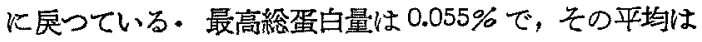
0.042\%である.

(4) オキシテトラサイクリン

全例とむ3时間では殆んど蛋白量増加して未らず， 6 時間で軽度の増加を示すが，24時間では注入前の值近 
くに戻つている・最高総蛋白量は $0.027 \%$ でその平均は $0.025 \%$ である・

(5)テトラサイダリン

注入前に比較すれば 3 時間目の值は少しく大きいが著 明なむのなく，6時間目でも2 例は 3 時間目のもの之殆 んど変りなく，1 例は少しく増加している程度で，24 時 間後には殆んぞ注入前の值に戾つている・最高総蛋白量 は $0.033 \%$ でその平均は $0.028 \%$ である・

(6) クロラムフェニ ニル

全例とも3時間で著明な蛋白量の増加があり，そのう ち1例では最高值を示している・他の 2 例では 6 時間後 に最高值をとり，24時間後では 2 例が 6 時間後の值と 同じであり，1 例は 3 時間目の値より少しく減少してい る，最高総蛋白量 $0.066 \%$ でその平均は $0.059 \%$ である。

(7) エリスロマイシン

3 時間目で 2 例は著明な増加を示し，1例は軽度であ るが，6時間目では更に堌加して最高値をとり，24 時間 目でもな和相当な増加を示している・最高総蛋白量 0.08 \%でその平均は $0.063 \%$ である。

小 括

ペニシリン，キシテトラサイタリンテトラサイク

リンでは著明な蛋白量の增加はなく，6時間目にや入增 加しているが，24時間目では 3 時間目ならびに注人前 の值に戾つている.その他のスルフアミン凨ならびに抗 生物質特にスプロナール，クロラムフェニコル，エリス ロマイシンでは 3 時間目にすで著明な蛋白量の増加を 示し，6時間目では更に増加するもの，あるいは3時間 目のものと変りないるのがあり，24時間目でもな和相 当な蛋白増加を示して拁り，6時間目の值と変りないも の，3時間目の値より大きいものなどがかなり見られ る.

薬珮注入に上る䯣液総蛋白量の平均值を比較してみる と、スルフアミン剂では，スプロナールが最高で 0.075 \%, ついでサイアジン 0.048\%，ドミアン0.043\%の順 であり，抗生物質では土リスロマイシンが最高で 0.063 \%, ついでクロラムフェニ=ル 0.059\%, ストレプトマ イシン $0.045 \%$ ，クロルテトラサイクリン $0.042 \%$ ，ペ= シリン0.031\%，テトラサイクリン0.028\%，オキシテト テサイタリン $0.025 \%$ の順である。

\section{IV. 総括並びに考按}

金野教授，潹瀕，林等によれば後頭下穿刺自身による 体温，一般状態の動摇は外少はあるが殆ど正常範囲内に あると言う・京た，生理的食塩水リンゲル氏液注入では
体温は下降あるいは上昇動摇を羊し，一般所見にも多少 影響があると言らが，鹿野によれば生理的食塩水 $0.2 c c$ 注入による体温の変動は $\pm 0.5^{\circ} \mathrm{C}$ 前後であり，一般症 状の発現はみていない，林恒第刺手技による体温の最高

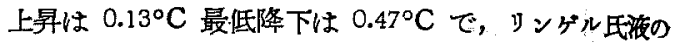
$1.0 \sim 0.5 \mathrm{cc}$ 注入では最高上卓 $0.5^{\circ} \mathrm{C}$, 最低降下 $1.4^{\circ} \mathrm{C}$ で，生理的食塩水 $1.0 \mathrm{cc}$ 注入で死亡したもの，0.5cc 注 入で猛烈な痓解を起したものがあると言つている・しか しこの 0.5〜1.0cc は僅か䯣液全量が 3〜 4cc 前後しか ない家鬼にとつては極めて大量であつて，金野教授，店 野の成績のように 0.2cc すなわち Pro k. 0.1 cc の少量。 であれば影響は少いししたがつてスルフアミン刘や五 スロマイシンのように強い一般㱏状を呈するすのは薬䘞 それ自身による影響と考光られる・また，スプロナール で死亡した例では体温の上昇をみることなく死に至つて いるが，鹿野の例でるストレプトマイシン $1 / 200 \mathrm{~g}$ 注入 2 時間後に死亡した例は体温の下降したまつである・そ の活かの例では一度低下した体温も3〜6時間後には上 矛し始め，その後㳄第に注入前の体温に近くなる・この 体温の変動は最初の $1 \sim 3$ 時間に激しく，体温变動のい らら゙るしいもの，とくに体温低下の甚しいものに一般症 状の強いものが多く恐められる。

血液白血球について金野教授は，過半数に打いて減少 症を前駆し，しかもその刺战程度の強いものほど減少症 の長く続くものが多いが，薬物の種類，動物の個性によ り，その過程俚一定していない。しかて，血中白血球曾

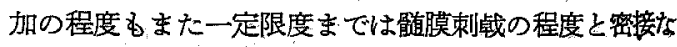
関係があり，刺战の強いるのおよび弱いるのは増加率が. 小で，中等度のむのは大であると言つている・林によれ ば㮔くのガス体注入により1時的に減少するものもある が，結局 6 時間後にはすべて増加を示し心・鹿野儿上札 ばペニシリンおよびストレプトマイシンでは著しい咸少 を示したすのはなく，その変動も軽度で，ベニシワン では3時間後，6時間後上くに6時間後に最高に道した あのが大多数で， 24 時間後には大多数のわのが 正常值 近く㞎るかあるいは少しく堌加の程度にあるが，たら、 例だけ 1200 の減少を示したものがあつた・ストレブト マイシンでも6 時間後に最高に達し，24 時間後に拮い てもな和軽度増加があつた。

私の成續では，スルフアミン剂はすべて白血球減少症 を前駆し，6時間後には著明な増加をきたし 24 時間後 でもな招相当な増加を示している・したがつてスルフフ ミン郕には相当な刺㦸性があると考えられ，その强さ任 
スブロナール, サイアジン，ドミアンの順である・抗生 物質についてみると, ペニシリン特よびテトラサイクリ 滦統のむのは血球の減少をきたすことなく，かつ 24 時間後には注射前の值より軽度の増加を示すだけで あるが，その最高増加平坞が 2000 前後であり，これら の薬削による刺㦸は強いものではないと考充られる・ク ロラムフェニニルはスルフブミン刘と類似の傾向があ り，エリスロマイシンでは，むしろ白血球減少症となる 㑯向が強いしたがつてこれらは強い刺战性があると考 えられる。

つぎに髄液の性状に及住す影響について，金野教授は

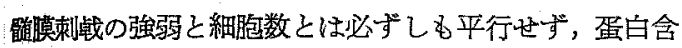
有量体㦸の強弱と平行して堌淢し，絧胞数と蛋白量と は必ずしも平行せず，䯚膜刺践は蛋白量を標準とすると 言つている・また家鬼䯠液の反復採取による細胞数の 增加は最高 7 , 蛋白量最高 $0.027 \%$ ，食塩水を家鬼体重 Prok. 0.1cc 注入の場合の細胞数堌加最高 23, 蛋白量最 高 0.025 と発表している・深攧によれば $0.85 \%$ 食㫫水 Prok. $0.1 \mathrm{cc}$ 注入の場合， 7 時間後に細胞数 10 , 蛋白量 0.0165, Prok. $0.25 \mathrm{cc}$ 注入の場合は細胞数 70 , 蛋白量 0.025 である・鹿野によれば生理的食塩水 $0.2 \mathrm{cc}$ 注 入後の細胞増加平均は 24, 蛋白質は $0.022 \%$ である・し たがつて薬成を生理的食塩水に溶解してそれを Prok. $0.1 \mathrm{cc}$ 注入した場合，䯣液内細胞数が 25 上上総蛋白量 が0.025\%以上のものがあれば，それは楽戍それ自身に よる影響と誉党られる。

私の央験成績では，ペニシリン，みキシテトラサイク。 リンならびルテトラサイクリンでは細胞増加数の平均が 30 前後であり，総蛋白量が $0.03 \%$ 前後であるので刺战は 軽度のると考えられる・またこれらの薬凧では24時 間後には大体注射前の值に戾つている・ストレプトマイ
シンとクロルテトテサイクリンでは細胞堌加平均が 50 前後，総蛋白量が $0.04 \%$ で，中等度の刺战があるすの と考えられ，かつ 24 時間後に蛙いてる相当な増加を宗 している・スルフアミン戍とくにスプロナールと，クロ ラムフェニニルならびにェッスロマイシンでは細胞増加 数平均 $力 570 \sim 100$ 前後あり，総蛋白量死 $0.06 \%$ 前後で, 强い刺战性があると考古られる・スルファミン剂の5ち ドミアンとサイアジンは総蛋白量が $0.045 \%$ 前後で中等 度のものであるが，細胞数の増加が 100 以上あり，かつ 一般状態の変動がかなりの程度に認められるから, 刺钱 性はストレプトマイシンとクロラムフェニュルの中間に 相当するものと思われる・

\section{V. 結 論}

1. ドミアン，サイアジン，スプロサール等のスルフ

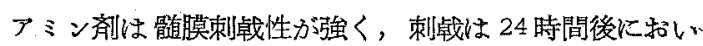
てもな沶租度に残つているので，䯟胵内に注人するこ とは不適当である。

2. 抗生物質に字䯠膜刺㦸性があり，ペニシリン，テ トラサイクリン，キキシテトラサイクリンを除けば剌战 は24時間後にるな泾残存している。

3. 抗生物筫のうち渻膜刺㦸の 軽度なるのはペニシリ ンテトラサイタリン，キシテトラサイクリンの3種 類で，中等度の刺㦸性のあるものはクロルテトラサイ。 クリンーストレプトマイシンの 2 種類, 高度の刺战性の あるものはクロラムフエニニルェリスロマイシンであ る・このうちオキシテトラサイクリンの刺战性が最も弱 W.

4. 脊椎管内注射法と乙て用い得る薬凧はペニシリン， テリラサイクリン，オシテトラサイクリンが適当と考 亲れる。

第 3 篇 抗生物質の䯣液内消長に関する奏験的研究

\section{目次}

1. 緒 言

II 実験方法

II実験成績

A，正常家患における髄液内消長

B-蹃膜炎家躳にお゙ける髄湤內消長

IV 稳括ならびに㨋按

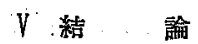

\section{I. 緒言}

抗生物啠を脊椎管内に注射した埸合，その有效量がで れはどの時間蹎液中に存在しているかを知ることは脊椎 管内注射療法の投与量ならびに投与回数を決定する上に 重要なものである・この点について鹿野は正常家乘にお いて，゚ニシリンは少くとも8〜9時間以内で有效作用 がなくなるが，ストレプトマイシンは24時間後に括い、 てもなお有效作用を保つと推定している・臨床的に永井 
はペニシリンは6時間までしか証明されなかつたと い, "中川等も 1 万〜 2 万単位では 24 時間後には 検出されず，3万単位以上注入の場合に 24 時間後 まで有数䜊度を保つと言つている Rhoadsは1〜2 万単位注入で 24 時間後にも䯣液内に满足すべき量 があつたとい〉, Rammelkamp はぺニシリン1万 単位注入で31 时間半をで証明して括り，中村も24 時間でなお有效量を検出し，脊椎管内注射は Pro. K. 200〜300 単位のペニシリンを 1 日 1 回注入でよ いとしている・辺む 24 時間まで訨明し，腰槽内 注入は 1 回 1 3 万単位 1日 1 2 回で十分と思らと 言つているが，箕田は絶えす゚䯠液中にペニシリンを 保持させるには1日2回2万举位を要すとして特 り，高原教授ならびに遊上は1日 1 2 2回の注入で は不十分と思われると言つて扰る・豊永はストレプ トマイシンでは24〜72 時間の有效作用を報告して いる・また髄荧炎の場合には更に長時間滞溜すると い5もの，反対に消失時間が短縮するというもの， あるいは消長には変化がないとするものなど一定し ていない.

第 2 篇の結果から背椎管内注射に用い,られる抗生 物質としてテトラサイクリン采統のものが考えられ るが，これらの抗生物質の消長に関しては未だ不明 である・そこで各種抗生物質の䯣液内消長について 比較検討した。

\section{II. 実 験方法}

ペニシリン1000 単位，その他の抗生物質は $0.5 \mathrm{mg}$ を含有する $0.2 \mathrm{cc}$ 生理的食塩水を $2 \mathrm{~kg}$ 前後の健康 家鬼および実験的䯣膜炎家鬼の後頭下腔に注入し， 一定時間の後に同じ場所から䯣液を採取して含有兽 を測定した。

薬斉の注入，採取はそれそれれ1回として連続採取 はは行わなかつた・

抗生物翼は枯草菌 MD-15 による宮村氏溥層かッ プ法によつて測定した。

実験的䯠膜炎を特こさせる方法は第 1 篇に記載し た通りである。

\section{III. 実験 成 續}

A. 正常家鬼に和ける䯣液的消長

1. ペニシリン（第 15 表，第 12 図）

6 時間後见括いても $0.04 \sim 0.2$ 単位の有效量が証明さ れるが，7時間以後では有效濃度を保つるのは非常に少 くなる・その消退時間は最初の 3 時間まで急速で，8時
第 15 表 ペニシリンの髄淮內消長 $1000 \mu / 0.2 \mathrm{cc}$ 注入

\begin{tabular}{|c|c|c|c|c|c|c|c|}
\hline 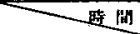 & 1 & $s$ & 6 & 7 & 12 & 18 & 21 \\
\hline 正常 豖 & $\begin{array}{r}86 \\
20 \\
72 \\
60 \\
66 \\
100 \\
84 \\
63\end{array}$ & $\begin{array}{l}16 \\
0.3 \\
0.6 \\
06 \\
18 \\
12 \\
28\end{array}$ & $\begin{array}{l}0.08 \\
0.06 \\
0.04 \\
0.13 \\
0.2 \\
0.06 \\
0.042 \\
0.07\end{array}$ & $\begin{array}{c}0 \\
0 \\
0.085 \\
0.08 \\
0 \\
0\end{array}$ & $\begin{array}{l}0 \\
0 \\
0\end{array}$ & & \\
\hline 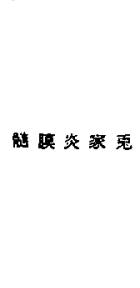 & $\begin{array}{r}88 \\
100 \\
126 \\
154 \\
120 \\
126 \\
138 \\
106\end{array}$ & $\begin{array}{r}93 \\
27 \\
60 \\
110 \\
120 \\
60 \\
22\end{array}$ & $\begin{array}{l}34 \\
356 \\
4.0 \\
80 \\
63 \\
25 \\
72\end{array}$ & $\begin{array}{l}1.2 \\
0.9 \\
18 \\
30 \\
1.7\end{array}$ & $\begin{array}{ll}0 & 04 \\
0 & 04 \\
0 & 07 \\
0 & 15 \\
0 & 06 \\
0 & 09\end{array}$ & 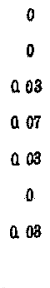 & $\begin{array}{l}0 \\
0\end{array}$ \\
\hline
\end{tabular}

第 12 図 ペニシリンの髄液內消長 100u/0.2cc 泩入

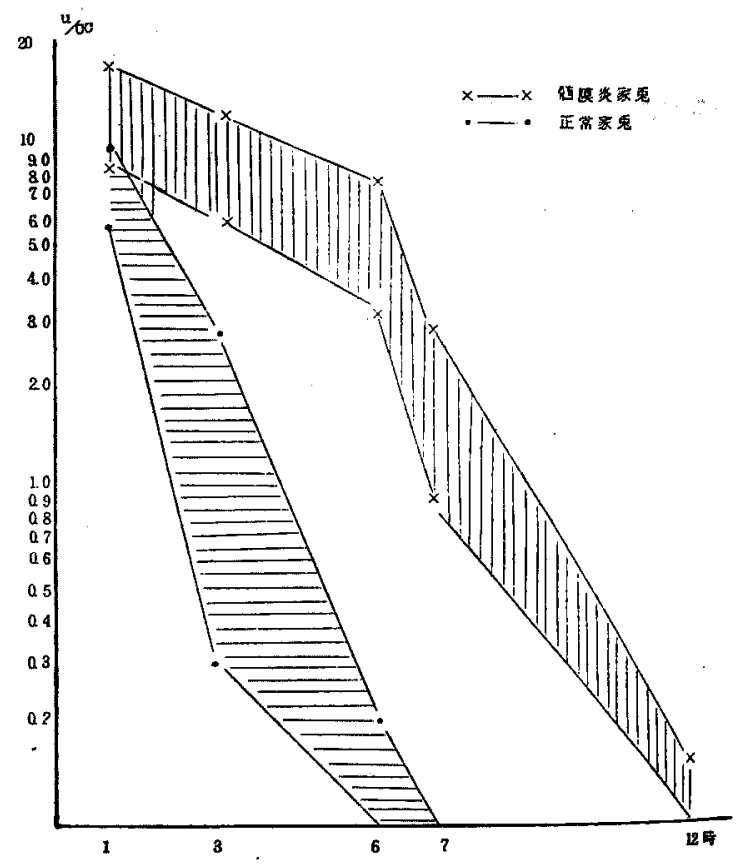

間以後では認められない.

2.ストレプトマイシン（第16表，第13図） 消退時間は最初の 6 時間まで急速であるが 24 時間後

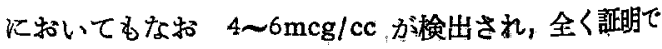
きなかつたものはない、ストレプトマイシンの有效浸度 
第 16 表 ストレプトマイシンの䯣没內消長 $0.5 \mathrm{mg} / 0.2 \mathrm{cc}$ 注入

\begin{tabular}{|c|c|c|c|c|c|c|c|}
\hline 工暲问 & 1 & $\mathrm{a}$ & 6 & 7 & 12 & 18 & 24 \\
\hline \multirow{6}{*}{ 正青 } & 55 & 38 & 14 & 10 & 8 & 8 & 4 \\
\hline & 48 & 39 & 12 & 11 & 7 & 6 & 4 \\
\hline & 42 & 40 & 16 & 9 & 8 & 6 & 6 \\
\hline & 57 & 42 & 12 & $g$ & 10 & 6 & \\
\hline & 60 & 53 & & 12 & & 8 & \\
\hline & 45 & & & & & & \\
\hline \multirow{6}{*}{ 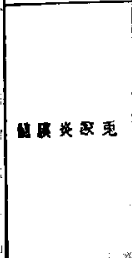 } & 61 & 55 & 21 & 13 & 7 & 12 & 5 \\
\hline & 53 & 50 & 32 & 20 & 7 & 6 & 8 \\
\hline & 50 & 46 & 36 & 18 & 8 & 9 & 8 \\
\hline & 50 & 48. & 28 & 14 & 13 & 9 & \\
\hline & 65 & 53 & 22 & 24 & 16 & 10 & \\
\hline & 57 & & & 23 & 10 & & , \\
\hline
\end{tabular}

第 13 図 ストレプトマイシンの髄液內消長 山! $0.5 \mathrm{mg} / 0.2 \mathrm{cc}$ 注入

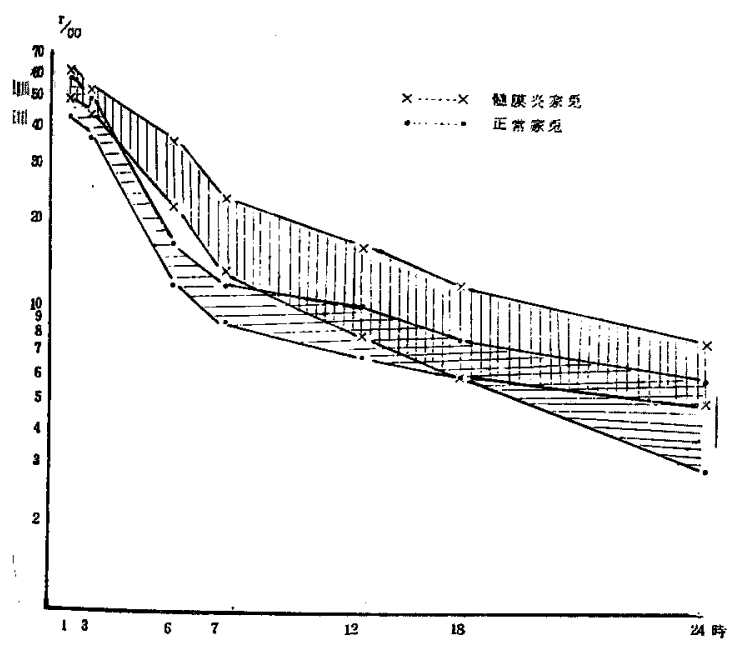

は大体 $6 \mathrm{mcg} / \mathrm{cc}$ であるので，24 時間後まで有效濃度 保つ可能性があると考觉られる。

3.クロルテトラサイタリン（第 17 表，第 14 図） 消退時間は最初の 7 時間まで急速であるが，その後の 消長は極めて少く；24 時間後に拉いても0.065 0.2mcg lec を含有している・テトラ゙サイタリン系統の最小発育

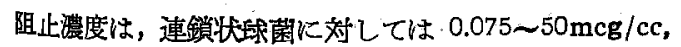
解炎双球菌に対しては $0.02 \sim 1.0 \mathrm{mcg} / \mathrm{cc}$ と言われてい
第 17 表 クロルテトラサイダリシの䯣液内消長

$0.5 \mathrm{mg} / 0.2 \mathrm{ce}$ 注入

\begin{tabular}{|c|c|c|c|c|c|c|c|}
\hline 工时的 & 1 & a & 6 & 7 & 12 & 18 & 24 \\
\hline \multirow{7}{*}{ 正耍 菭 } & 13 & 10 & 3 & 0.8 & a 3 & Q 13 & 0 065 \\
\hline & 126 & 8 & 42 & 26 & 0.5 & a 16 & 0.08 \\
\hline & 12 & 8 & 5 & 4 & a. 5 & Q 43 & 0.13 \\
\hline & 143 & 25 & 7 & 1.8 & 0.9 & $Q_{4}$ & Q 2 \\
\hline & 12 & 14 & 5. 8 & 1.6 & 083 & 06 & \\
\hline & 16 & & & & & & \\
\hline & 14.2 & & & & a. 9 & Q 52 & \\
\hline \multirow{6}{*}{ 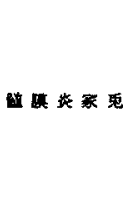 } & 158 & 14 & 10 & 3. 5 & 1. 3 & Q 8 & 0.08 \\
\hline & 15 & 11 & 5 & 5 & 30 & 12 & 04 \\
\hline & 17 & 16 & 8 & 54 & 24 & 1 & Q 4 \\
\hline & 195 & 18 & 12 & 8 & 24 & 15 & 0 35 \\
\hline & 20 & & 25 & 7 & $3_{4}$ & 25 & 06 \\
\hline & 203 & & & & 16 & & \\
\hline
\end{tabular}

第 14 図クロルテトラサイクリンの髄液队消長

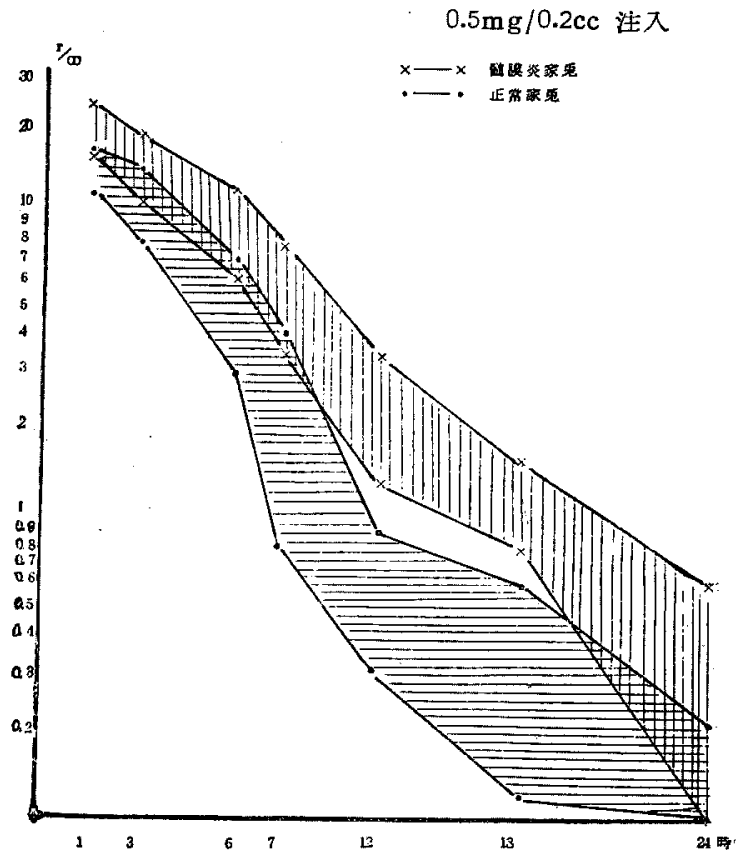

るので，クロルテトシサイタリンは24時間後までも有 效量を保持し得る場合もあると考えられる・

4.オキシテトラサイタリン（第18丧, 第 15 図）

最初の 6 時間までの消長が激しく，7時間では 0.13〜 $0.45 \mathrm{mcg} / \mathrm{cc}$ となり，12 时間では検出できない場合もあ り，18時間では6例中 1 例だけに $0.03 \mathrm{mcg} / \mathrm{cc}$ を証明 できた。したがつて 12 時間上上では有效濃度を期待で きない。

$$
\text { 5. テトラサイタリン（第 } 19 \text { 表，第 } 16 \text { 図） }
$$


第 18 表、オキシテトラサイクリンの䯣液內消長 $0.5 \mathrm{mg} / 0.2 \mathrm{cc}$ 注入

\begin{tabular}{|c|c|c|c|c|c|c|c|}
\hline (7一时 & 1 & 3 & 6 & 7 & 12 & 18 & 24 \\
\hline \multirow{3}{*}{$\approx$} & 18 & 4 & 0.74 & a 13 & 0 & 0 & \\
\hline & 20 & 43 & 26 & a 23 & 0 & 0.03 & \\
\hline & 23 & 9 & 09 & $a 28$ & 009 & 0 & \\
\hline \multirow[t]{4}{*}{ 正榙 家 } & 23 & 26 & 1.5 & a 45 & 0.03 & 0 & \\
\hline & 27 & 13 & 28 & , & a 07 & & \\
\hline & 24 & 14 & 26 & & 0 & & \\
\hline & 19 & & & & & & \\
\hline \multirow{6}{*}{ 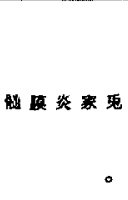 } & 22 & 13 & 8 & 8 & 06 & 008 & 0 \\
\hline & 26 & 20 & 12 & 6 & 0.8 & 04 & 0 \\
\hline & 26 & 25 & 16 & 7 & 22 & 04 & 0.06 \\
\hline & 28 & 18 & 14 & 6 & 25 & 0.7 & \\
\hline & 80 & & 17 & 11 & & & \\
\hline & 80 & & & & & & \\
\hline
\end{tabular}

第 15 図 ホキシテトラサイクリンの䯣源內消長 $0.5 \mathrm{mg} / 0.2 \mathrm{cc}$ 注入

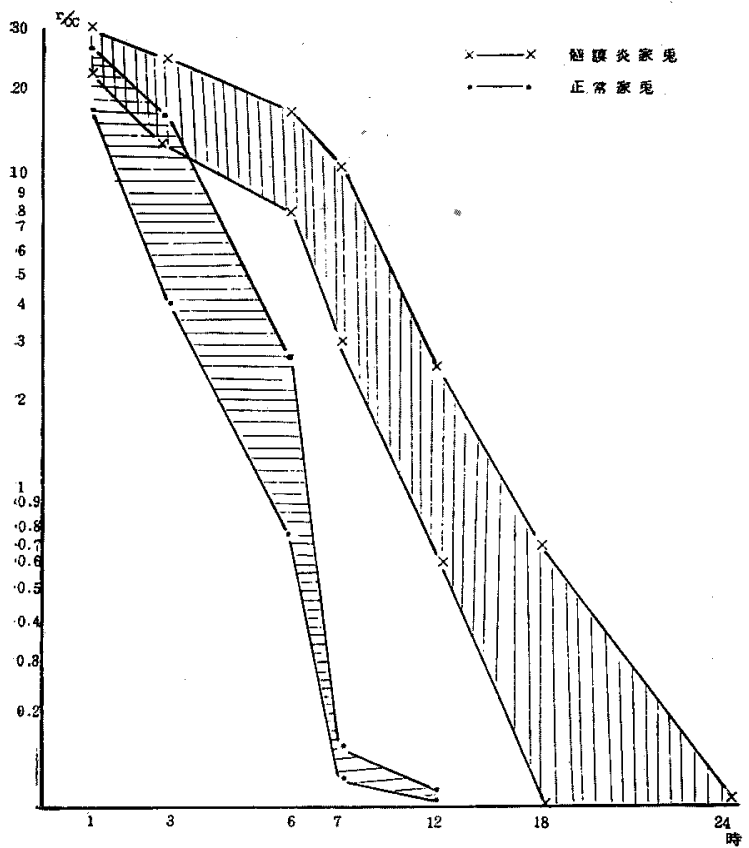

これはオキシテトラサイクリンと非常に似た傾向を示 しているが，18時間後でも6例中 3 例に有効量を証明 できるので 12 時間以上の有效作用に希望がもたれるが， 12時間で検出されなかつた例が6例中2 例あることは注 意すべきこと〉思う・

6.クロ

この消長は最初の6 時間まで非常に急で，3時間では $11 〜 24 \mathrm{mcg} / \mathrm{cc}$ であるが6時間では $6 \sim 16 \mathrm{mcg} / \mathrm{cc}$ とな
第 19 表 テトラサイクリンの髄液肉消長

$0.5 \mathrm{mg} / 0.2 \mathrm{cc}$ 注入

\begin{tabular}{|c|c|c|c|c|c|c|c|}
\hline 3 時 & 1 & $\mathbf{a}$ & 6 & 7 & 12 & 18 & 24 \\
\hline \multirow{6}{*}{ 正寞 鬼 } & 17 & 6 & 05 & 03 & 0 & 0 & \\
\hline & 28 & 8 & a. 6 & 07 & 0 & 0 & \\
\hline & 22 & 18 & 09 & 1.8 & 03 & $a_{1}$ & \\
\hline & 25 & 14 & 4 & 2 & 03 & & \\
\hline & 22 & 14 & 43 & & 06 & & \\
\hline & 19 & & 8 & & & & \\
\hline \multirow{5}{*}{ 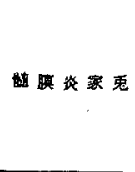 } & 24 & 16 & 10 & 6 & 2 & 07 & 0 \\
\hline & 24 & 16 & 15 & 12 & 2 & a 9 & 03 \\
\hline & 26 & 18 & 11 & 11 & 7 & 15 & 05 \\
\hline & 28 & 20 & 19 & 11 & 8 & 28 & \\
\hline & & 28 & & 13 & & 2 & \\
\hline
\end{tabular}

第 16 図テトラサイクリンの髄液内消長

$0.5 \mathrm{mg} / 0.2 \mathrm{cc}$ 注入

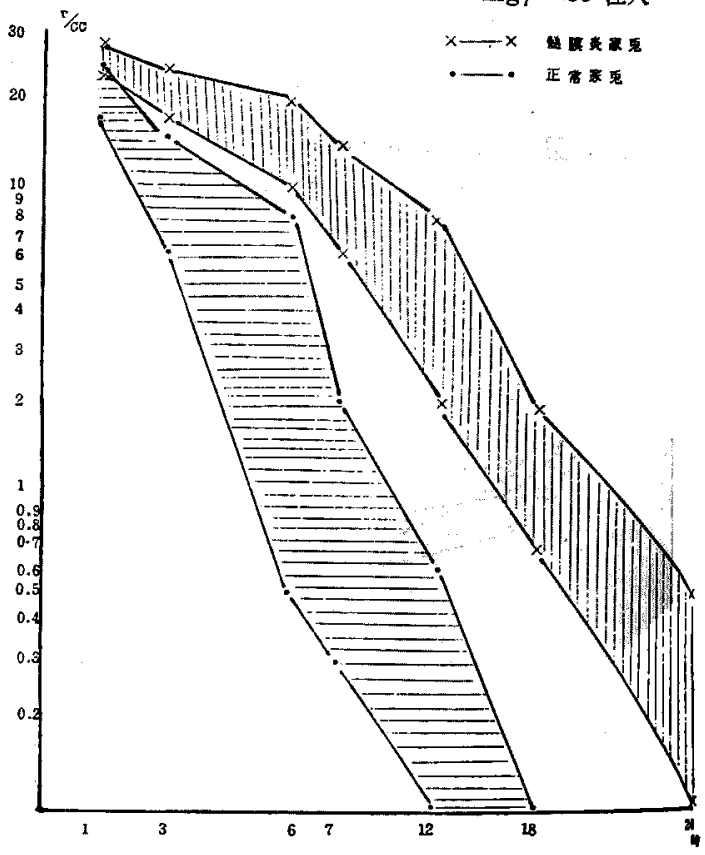

り、7 時間では 6 例中 1 例では検出ができず，12時間で は6 例中 2 例に証明できず，18 時間てては 3 例険索して 証明できなかつた・クロラムフェニニルの最小登育阻止 濃度は連鎖状球菌に対しては $0.75 \sim 5.0 \mathrm{mcg} / \mathrm{cc}$; 肺桨双 球菌に対しては $0.312 \sim 2.5 \mathrm{mcg} / \mathrm{cc}$ であるので，6時間 までは磷実に有效量を保持できるが，12時間以後ては 期待されないと考えられる。

$$
\text { 7.エリスロマイ・ジ（第 } 21 \text { 表，第 } 18 \text { 図） }
$$

この場合も最初の消長は急激であるが、12時間以後 
第20第，ク口ラムフ亡三ニルの䯣液内消長

$0.5 \mathrm{mg} / 0.2 \mathrm{cc}$ 注入

\begin{tabular}{|c|c|c|c|c|c|c|c|}
\hline 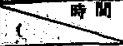 & 1 & 3 & 6 & 7 & 12 & 18 & 24 \\
\hline \multirow{5}{*}{ 正 $*$ 家 } & 18 & A1 & 6 & 0 & 0 & 0 . & \\
\hline & 25 & 20 & 8 & 0 & 0 & 0 & \\
\hline & 30 & .22 & 18 & 6 & 1.6 & 0 & \\
\hline & 28 & 24 & 13 & 8 & $z$ & . & \\
\hline & 36 & & 16 & & 23 & & \\
\hline \multirow{6}{*}{$\begin{array}{c}\ldots \\
\ldots \\
\ldots\end{array}$} & 25 & 17 & 11 & 7 & 4 & 1 & 0 \\
\hline & 28 & 17 & 14 & 9 & 7 & 24 & 0 \\
\hline & 30 & 20 & 16 & 8 & 6 & 8 & 1 \\
\hline & 30 & 22 & 16 & 12 & 7 & & 1 \\
\hline & 35 & & 18 & & & & \\
\hline & 38 & & & & & & \\
\hline
\end{tabular}

第 17 図 タロラムフエニコルの鹃液內消長 $0.5 \mathrm{mg} / 0.2 \mathrm{cc}$ 注入

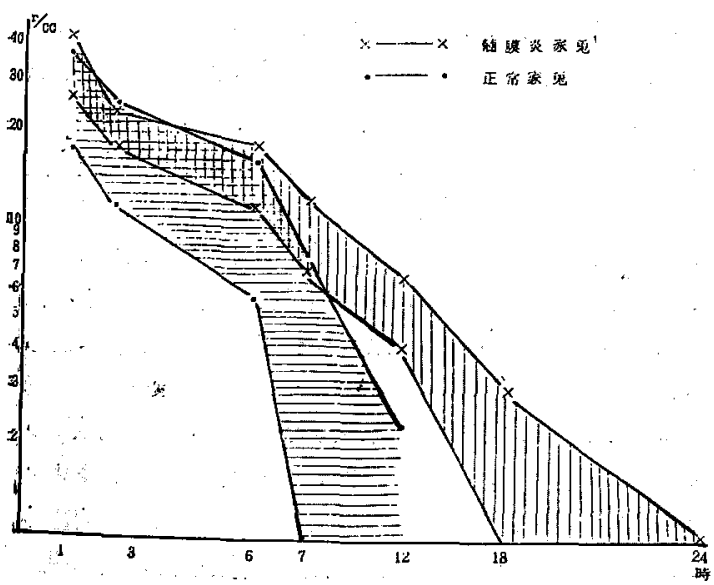

は榋めてゆるやかとなり，24時間後においても 0.04 $0.07 \mathrm{mcg} / \mathrm{cc}$ が検出される・この薬剤の最小発育阻止濃 度怯連鎖状球菌に対しては $0.02 \sim 3.1 \mathrm{mcg} / \mathrm{cc}$, 肺炎双球 菌に対しては $0.0 \mathrm{l} \sim 0.156 \mathrm{mcg} / \mathrm{cc}$ であるから，エリス ロマイシンの有効作用は 24 時間後においてい期待され る.

\section{B. 骮膜炎家東における鹃迹液内消長

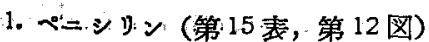

䯓液内消長の曲線は非常にゆるやかとなり、12 時間
第21.表 エリスロマイシンの噵㳔肉消長: $0.5 \mathrm{mg} / 0.2 \mathrm{cc}$ 注入

\begin{tabular}{|c|c|c|c|c|c|c|c|}
\hline 二時觕 & 1 & 3 & 6 & 7 & 12 & 18 & 24 \\
\hline \multirow{6}{*}{ 正䆖 } & 20 & 14 & 9.7 & 5 & 0.8 & 02 & 004 \\
\hline & 24 & 18 & 8 & 5 & a 9 & a 2 & 006 \\
\hline & 24 & 16. & 13 & 6 & id & 0.6 & 006 \\
\hline & 32 & 20 & 20 & 14 & L. 7 & 1.2 & 0.07 \\
\hline & 38 & 25 & 22 & 18 & 23 & 25 & 007 \\
\hline & - & 31 & & & & & \\
\hline \multirow{6}{*}{ 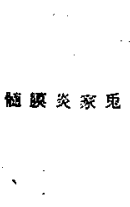 } & 32 & 26 & 17 & 14 & 3 & Q. 7 & 02 \\
\hline & a 6 & 28 & 17 & 16 & 7 & 0.7 & 0.4 \\
\hline & 44 & 86.5 & 22 & 19 & 12 & 0.8 & 04 \\
\hline & 39 & 29 & 20 & 23 & 11 & \& 6 & 0.7 \\
\hline & 45 & a 0.7 & 32 & 27 & 14 & 55 & 08 \\
\hline & & 37 & & & & & \\
\hline
\end{tabular}

第 18 図エリスロマイシンの鹃液內消長 $0.5 \mathrm{mg} / 0.2 \mathrm{cc}$ 注入

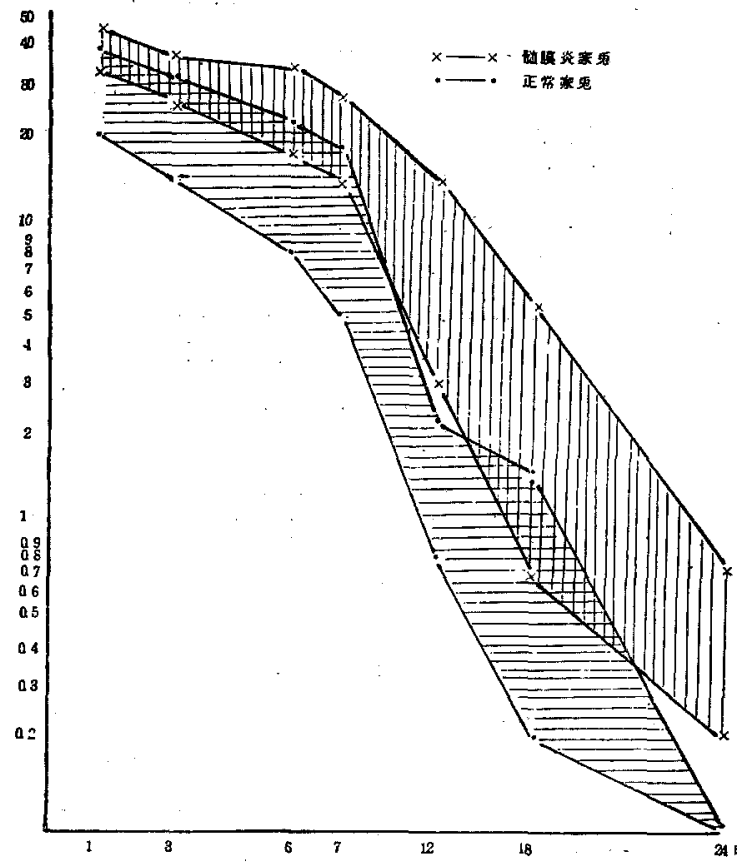

後においても 0.04 0.15 単位の有效濃度があり，18 時 間後においてるなお 0.07 単位を証明した例がある・し たがつて 18 時間むでの有效作用を期待できそうに思わ れる。

2、ストレプトマイシン（第16表，第 13 図）

正常家鬼に見られたような最初の急激な減少はなくな $り$ ，長時間高濃度の髄液内滯溜が見られるが，24 時間 では 5〜8mcg/cc で正常の場合と大差は認められない。 
3.タロルテトラサイクリン（第17表，第14図）

これはストレブトマイシンの場合と殆んど同じ経過を とつており，最初の急激な 減少はないが 24 時間值では 正常の場合と大差がない.

4.オキシテトラサイクリン（笏 18 表, 第 15 図)

正常家鬼の場合には 12 時間以上では有效作用を其待 できないが，髄膜炎家鬼では 18 時間で 0.08〜 $0.7 \mathrm{mcg} / \mathrm{cc}$ が检出され，更に 24 時間でも $0.06 \mathrm{mcg} / \mathrm{cc}$ を証明でき た例があるので 18 時間までは有效作用があると考えら れる。

5.テトラサイクリン（第 19 表, 第 16 図）

正常家象の嚗合， 12 時間で 6 例中 2 例に扔いて検出 できなかつたが，髄膜炎家鬼では 12 時間値 2 8mcg/ cc という高濃度にあり，18時間です $0.7 \sim 2 \mathrm{mcg} / \mathrm{cc}$ が 証明され，24時間でも $0.5 \mathrm{mcg} / \mathrm{cc}$ を検出した例がある。 したがつて 18 時間までの有效作用は確実と考えられる・

6. クロラムフエニコル（第 20 表, 第 17 図)

この場合にも消退時間の延長と，消長の量に秃いて相 違が認められ，18 時間值 1〜3mcg/cc を証明し， 24 時 間でも $1 \mathrm{mcg} / \mathrm{cc}$ を検出した例がある。

7. エリスロマイシン（第21表，第 18 図）

この場合は正常家東に比較して特に消退時間の延長と 量の相違が譛められる・24 時間値で正常の場合は 0.04 〜 $0.07 \mathrm{mcg} / \mathrm{cc}$ であるが; 髄膜炎家東では $0.2 \sim 0.8 \mathrm{mcg}$ /ccという高濃度が検出された・

\section{IV. 総括並びに考按}

以上の成結を総括すると，正常家束の場合にはべニシ リン，オキシテトラサイクリンテトラサイクリン， ロラムフェニコルは韨液腔からの消退が早く、ペニシリ ンでは 6 7 時間, その他の抗生物質では 12 時間以上の 有效作用は期待できないと考党られる・ストレプトマイ シンクロルテトラサイクリンエリスロマイシンでは 消退が遅く，24時間後に括いてもな和有效量が検出さ れている。

正常家鬼に打いて消退時間の早い抗生物質について喠 膜炎の場合をみると，著明な消退時間の延長が認めら れ，12 時間以上の有效作用が 認められないむのが，䯣 膜炎の際には18時間までの有效作用は磪実と考兄られ る.

また正常でも 24 時間以上も滞溜しているストレプト マイシン，クロルテトラサイクリン，エリスロマイシン の䯣膜炎家鬼に和ける䯣液内消長についてみると，消退 時間の変化は著明ではないが，消退してゆく量に相違が
認められ；最初の急激な減少は少なく，非常にゆるやか。 な曲線を画いている・

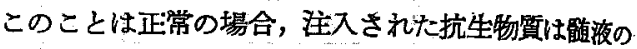
生理的生成および排出による稀釈，減少するばかりでな

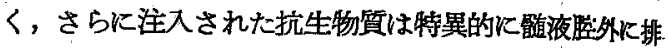

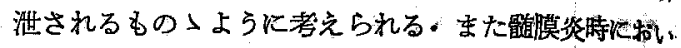
て消退の延長するのは䯣液の生成，吸収の異常が起り， 異物としての抗生物質の吸収排除の作用が低下している. ためと考えられる・当教室にて行われた一条の実駼的砛

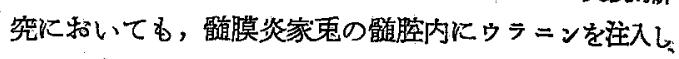
てその尿中排洺速度を調查した場合，正常家東ではッ ニンの尿中完の発現時間は注入後 $7 \sim 13$ 分であり, 5 時 間後に技ける排泄総量は 34.6〜61.3\% であり，路膜炎家 鬼ではウランンの発現時間は9〜15 分となり5時間後の. 尿中排泄総量は 23.3〜38.2\% となつて著明な減少をきた

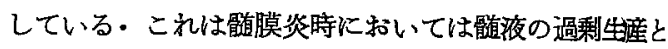

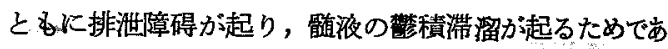
ると言つている。

第 2 篇にのべたように，髄膜刺㦸の軽度な抗生物質忚 ペニシリンテテトラサイクリン，オキシテトラサイクリ ンであり，中等度のむのはクロルテトラサイクリン, ス トレプトマイシンで, 高度のものはクロラムフエニュ ルエリスロマイシンである・この刺战性と䯕派内消長

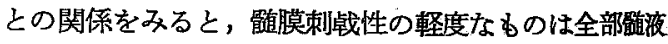
からの排泄が速く，刺㦸性中等度和よび高度なるのでは 排泄が遅く24時間後においてもな挌残存している・た だしクロラムフメニコルは刺战が高度であるにかつわら す随液㓐からの消退は速い.

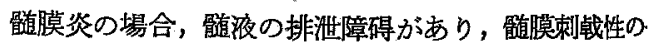
軽度なべニシリン，テトラサイクリン，オキシテトラサ イクリンでも少くとも 18 時間位までの間は骮朊内に必 要量が残存しているので脊椎管内注射潦法の場合顸回 に䯣腔内に注射するのはいたづらに檤膜を剌战するだけ であり，1日の注射回数は 2 回に止むべきものと考党ら れる。

\section{V. 結 、論}

1. 正常家鬼ではペニシリン，オキシテトラサイクリ

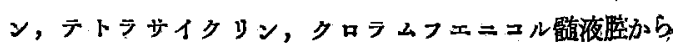
の排泄が速く，6〜7時間で消退する・ストレプトマ1 シン，クロルテトラサイクリンエリスロマイシンでは 排泄遅く24 時間後にむなお相当量が残存している。

2. クロラムフェニコルをの ぞけば，髄脱刺战の軽度 なものは䯣液腔からの排泄が速く，剌战の強いすのは造 
tie

3. 解膜桊家香の場合には薬剂の排泄が遅延し，18〜 24 時間後においても有效量が残存している。
4. 背椎管内注射は1日2 回までに止むへさであると 考えられる。

\section{第 4 篇 抗生物質の䯣液内移行度を高める補助薬剂}

目次

1 䌋 言

11実験方法ならびに実験成績

1. ヒアルロ=ダーゼ

2. メ゙・ブロ ミン

3. ニコチン酸アミド

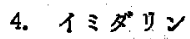

III總括ならびに゙考按

N. 結 論

\section{I. 緒 言}

全身的涙用いられた抗生物質の䯣夜内移行度は不十 分ないが多く，髄腔内注射では多少とる髄膜刺战が

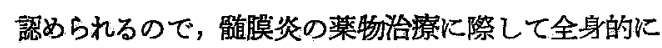
使用した抗生物質の啁道液内移行度を堌加させる手段が あれ渄常に效果的之考えられる。

この問題について，かつて前田は䪔液の反復採取，モ ルヒネ，重硝酸ッーダ，ビロカルピン，ピッイトリン，

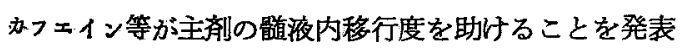
し，ついで梁瀬がこれを追試して礁楒している。

金野教授は宿題報告に未いて血液艏夜関門の所在は的道 设腔を形成する軟膜就よび脈絡丵の全毛細管壁にあるこ とを報告され，真下はスルフアミン剂の喵液移行の実験

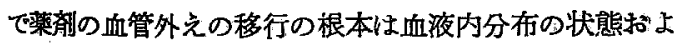
び血管壁の状態に左右されると述べているので，血管壁 に直接にあるいか植物神経系を介して間接に作用する楽 剬として，ヒアルロ=ダーゼ，メトブロミン，=ニチン 酸アミド,イミダリンを選んでこれらが抗生物質の䯠液 内移行を助けるかどうかを袷討した・

\section{II. 実験方法並びに実験成績}

実畭動物は体重 $2 \mathrm{~kg}$ 前後の正常家鬼を用い; 抗生物 質には比較的よく移行するクロラムフェニコルと移行度 の悪いエリスロマイシンならびにペニシリンを撰んだ。

1. 七アルロニダーゼの髄液内移行度に及ぼす影響

ヒアルロニダーぜ 1000 単位にクロラムフエニコル 10 $\mathrm{mg} / \mathrm{kg}$ を索混合して静注した場合の成績は第 22 表に示 ¿た.

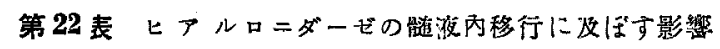
正常策鬼

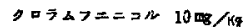

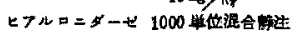

\begin{tabular}{|c|c|c|c|c|c|}
\hline & 30 & 1 & 2 & 3 & 6 \\
\hline 1 & 82 & 6.6 & & 82 & 26 \\
\hline 2 & 28 & & 52 & 21 & 18 \\
\hline 3 & 55 & 84 & 48 & 35 & 21 \\
\hline 4 & 4.8 & 28 & 38 & 17 & 18 \\
\hline 5 & 25 & 62 & & 22 & 24 \\
\hline 6 & 10 & & 62 & & \\
\hline 7 & & 45 & & & \\
\hline
\end{tabular}

正㑒家象

メリスロマインン $10 \mathrm{mg}$ 亿⿻

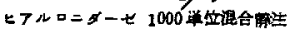

\begin{tabular}{|c|c|c|c|c|c|}
\hline 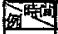 & 30 & 1 & 2 & 3 & 6 \\
\hline 1 & \pm & & Q. 052 & 008 & \pm \\
\hline 2 & \pm & a 085 & 006 & 0025 & 005 \\
\hline 3 & 005 & 0.08 & & a 662 & \pm \\
\hline 4 & Q 038 & a 048 & a cas & & \pm \\
\hline 5 & $\begin{array}{l}0.3 \\
0\end{array}$ & a 33 & a 16 & 004 & 008 \\
\hline 6 & \pm & $a 22$ & a 078 & & \\
\hline
\end{tabular}

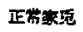

デシシリン 2 万些位

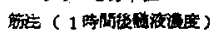

\begin{tabular}{|c|c|}
\hline 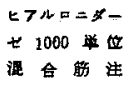 & $\begin{array}{l}\text { ヒアルロニター } \\
+1000 \text { 位 } \\
\text { 柱 }\end{array}$ \\
\hline 0097 & 0102 \\
\hline 0088 & 009 \\
\hline 0084 & 0085 \\
\hline 0.076 & 008 \\
\hline 0071 & \pm \\
\hline \pm & 0.082 \\
\hline \pm & 0068 \\
\hline 0 & 0.054 \\
\hline 0 & 0 \\
\hline 0 & 0 \\
\hline
\end{tabular}

すなわち 30 分後では $2.8 \sim 5.5 \mathrm{mcg} / \mathrm{cc}, 1$ 時間 $4.5 \sim$ $8.4 \mathrm{mcg} / \mathrm{cc}, 2$ 時間 $3.3 \sim 6.2 \mathrm{mcg} / \mathrm{cc}, 3$ 時間 $1.7 \sim 3.5 \mathrm{mcg}$ $/ \mathrm{cc}, 6$ 時間 $1.8 \sim 2.6 \mathrm{mcg} / \mathrm{cc}$ である。

ヒアルロニダーゼ1000単位にメリスロマイシン10mg/ $\mathrm{kg}$ を混合して静注した場合の成績は第 22 表に示した・

すなわち 30 分後では痕跡栐 3 例でその他は 0.03 $0.05 \mathrm{mcg} / \mathrm{cc}, 1$ 時間痕跡榚 2 例之の他の例は $0.08 \sim 0.33$ $\mathrm{mcg} / \mathrm{cc}, 2$ 時間痕跡様 1 例でその他は $0.05 \sim 0.16 \mathrm{mcg} /$ cc，3 時間痕跡様 1 例で，その他の 4 例は $0.025 \sim 0.08$ $\mathrm{mcg} / \mathrm{cc}, 6$ 時間後では痕跡様 3 例で他の 2 例は $0.036 \sim$ $0.05 \mathrm{mcg} / \mathrm{cc}$ である.

ペニシリン 2 万単位とヒアルロニダーゼ 1000 単位を 混合筋注した盼合，ならびにペニシリン 2 万単位筋注と 同時にヒアルロニダーゼ 1000 単位を 静注した場合の1 時間後に特ける成績は第22 表に示した。

ペニシリンは正常家東では移行は証明されないが，ヒ アルロニダーゼを併用すると著明に移行する場合があ る・しかしてその移行度は䪔膜炎家乘に静注した場合よ り幾分良好である。

2. ホトブロミンの髄液内移行度に及洔す影響 クロラムフェニコル $10 \mathrm{mg} / \mathrm{kg}$ を静注し，その直後に 
第23表メトブロミンの䯣液內移行に及に゙す影望

エリスローインン $10 \mathrm{mg} / \mathrm{kg}$ 骴

メトフロシン 0 $5 \propto 0$ 枌社

つロラムフェニニル $10 \mathrm{mg} / \mathrm{kg}$

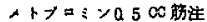

\begin{tabular}{|c|c|c|c|c|c|}
\hline & 30 & 1 & 2 & 3 & 6 \\
\hline 1 & 28 & 92 & 58 & 53 & \\
\hline 2 & 62 & 54 & 48 & 23 & 24 \\
\hline 8 & 44 & 87 & 98 & 21 & 18 \\
\hline 4 & 35 & 64 & 66 & 18 & 16 \\
\hline 5 & 22 & & 24 & 23 & 16 \\
\hline
\end{tabular}

\begin{tabular}{|c|c|c|c|c|c|}
\hline 睢的逝 & 30 & 1 & 2 & 3 & 6 \\
\hline I & \pm & 0.084 & 008 & 0075 & \\
\hline 2 & & 0.055 & 0054 & & \pm \\
\hline 3 & & & & 0,043 & \pm \\
\hline 4 & 0.03 & Q 0 ? & 0.068 & & \\
\hline 5 & & & & 0,02 & 0.044 \\
\hline 6 & 0045 & 0.07 & 0.045 & & \\
\hline 7 & \pm & 04 & 005 & 003 & \pm \\
\hline 8 & & Q.11 & & & 0.054 \\
\hline 9 & & & & & a 018 \\
\hline
\end{tabular}

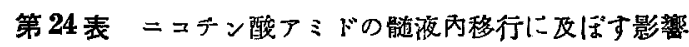

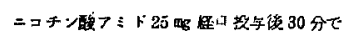
クロラムフエニコル $10 \mathrm{mg} / \mathrm{kg}$ 骫注

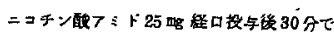

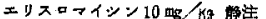

\begin{tabular}{|c|c|c|c|c|c|}
\hline 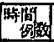 & 80 & 1 & 2 & 3 & 6. \\
\hline 1 & 2.8 & 28 & 6.2 & 25 & 1. 5 \\
\hline 2 & 34 & 65 & 4. 5 & 4. 3 & 25 \\
\hline 3 & 2.4 & 4. 8 & 56 & 58 & 1.8 \\
\hline 4 & 55 & 7. 7 & 68 & 4.5 & 22 \\
\hline 5 & & & & & \\
\hline 6 & & & & & \\
\hline
\end{tabular}

\begin{tabular}{|c|c|c|c|c|c|}
\hline 橴政 & 30 & 1 & 2 & 3 & 6 \\
\hline 1 & \pm & 0.058 & 0.086 & 0.078 & \pm \\
\hline 2 & 0.06 & 0.38 & 0.05 & 0.052 & 0.032 \\
\hline 3 & 0.054 & 0.12 & 0.05 & 0.08 & 0.045 \\
\hline 4 & & 0.08 & 0.07 & 0.03 & \\
\hline 5 & 0.03 & & & & \pm \\
\hline 6 & & & & 0.14 & \\
\hline
\end{tabular}

すなわち 30 分 $2.4 \sim 5.5 \mathrm{mcg} / \mathrm{cc}$ ， 1 時間 $4.8 \sim$ $7.8 \mathrm{mcg} / \mathrm{cc}$ ，2時間 $4.5 \sim 6.8 \mathrm{mcg} / \mathrm{cc}$, 3 眭間 $2.5 \sim$ $5.8 \mathrm{mcg} / \mathrm{cc}, 6$ 時間 $1.5 \sim 2.5 \mathrm{mcg} / \mathrm{cc}$ である。

ニコテン酸けミド $25 \mathrm{mg}$ 経口投与 30 分後ニリス ロ、インン $10 \mathrm{mg} / \mathrm{kg}$ 静注した場合の鄙液内移行 成績は第 24 表に示した。

30 分後では, 痕跡样 1 例で他の 3 例は 0.03 $0.06 \mathrm{mcg} / \mathrm{cc} ， 1$ 時間 $0.058 \sim 0.38 \mathrm{mcg} / \mathrm{cc} ， 2$ 時間 $0.05 \sim 0.086 \mathrm{mcg}$, 3時間 では痕跡樣 1 例で他の 5 例 は $0.03 \sim 0.14 \mathrm{mcg} / \mathrm{cc} ， 6$ 時間では痕䟞様 2 例で他 の 2 例は $0.032 \sim 0.045 \mathrm{mcg} / \mathrm{cc}$ である.

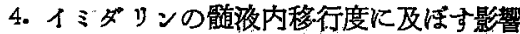

イミダリンlcc 皮下注射し，クロラムフェニシ $ル 10 \mathrm{mg} / \mathrm{kg}$ 静注した場合の髄液内移行成跣性第 25 表に示した。

30 分後では $1.35 \sim 5.0 \mathrm{mcg} / \mathrm{cc}, 1$ 時間 $2.8 \sim 6.0$. $\mathrm{mcg} / \mathrm{cc}, 2$ 時間 $2.5 \sim 5.6 \mathrm{mcg} / \mathrm{cc}, 3$ 㭙間 $1.8 \sim 4.0$ $\mathrm{mcg} / \mathrm{cc}$; 6 時間では 1.6〜2.8 $\mathrm{mcg} / \mathrm{cc}$ である。

ヘミダリン 1cc 皮下注射し，エリスロマイシン 10 メトブロミン $0.5 \mathrm{cc}$ を筋注した場合の成續は第 23 表に 示した。

30 分後では $2.2 \sim 6.2 \mathrm{mcg} / \mathrm{cc}, 1$ 時間 $5.4 \sim 9.2 \mathrm{mcg} / \mathrm{cc}$, 2 時間 $4.8 \sim 9.3 \mathrm{mcg} / \mathrm{cc}, 3$ 時間 $1.8 \sim 5.3 \mathrm{mcg} / \mathrm{cc}, 6$ 時間 では $1.6 \sim 2.4 \mathrm{mcg} / \mathrm{cc}$ である・

エワスロマイシン $10 \mathrm{mg} / \mathrm{kg}$ を埥注し，その直後メ、 プロミン $0.5 \mathrm{cc}$ 筋注した場合の成績は第 23 表に示した。

すなわら 30 分後痕跡様 2 例，他の 2 例では 0.03 $0.045 \mathrm{mcg} / \mathrm{cc}, 1$ 時間 $0.055 \sim 0.4 \mathrm{mcg} / \mathrm{cc} ， 2$ 時間 $0.045 \sim$ $0.08 \mathrm{mcg} / \mathrm{cc} ， 3$ 時間痕跡様 2 例，他の 4 例 では 0.02 $0.075 \mathrm{mcg} / \mathrm{cc}, 6$ 時間では痕跡様 3 例で他の 3 例は 0.018 $\sim 0.054 \mathrm{mcg} / \mathrm{cc}$ である.

3. ニコチン酸アミドの酭液内移行度に及ぼす影響

ニコチン酸アミド $25 \mathrm{mg} / \mathrm{kg}$ 経口投与後 30 分でクロ ラムフェニニル $10 \mathrm{mg} / \mathrm{kg}$ を静注した場合の移行成績は 第24 表湫示した。

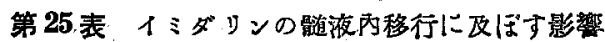

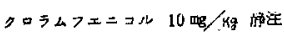
エリスロマイッン $10 \mathrm{mg} / \mathrm{kg}$ 1ミダリン100 皮下注射

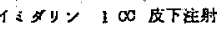

\begin{tabular}{|c|c|c|c|c|c|}
\hline 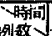 & 80 & 1 & 2 & 3 & 6 \\
\hline 1 & 1.3 & 50 & 25 & 40 & 1.8 \\
\hline 2 & 18 & 60 & $\overline{4 \cdot 8}$ & 2.3 & \\
\hline 3 & 50 & 28 & 56 & 21 & 22 \\
\hline 4 & & 58 & 36 & 18 & 28 \\
\hline 5 & 45 & 38 & & 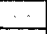 & 1.6 \\
\hline 6 & & & & & \\
\hline & & & & & \\
\hline
\end{tabular}

\begin{tabular}{|c|c|c|c|c|c|}
\hline 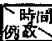 & 30 & 1 & 2 & 3 & 6 \\
\hline 1 & \pm & & \pm & \pm & \pm \\
\hline 2 & 0 & & & \pm . & \\
\hline 3 & 0 & & 0.05 & & $\dot{I}$ \\
\hline 4 & a. 032 & 0.082 & 0.023 & 0,042 & 0 \\
\hline 5 & 0.015 & 0.08 & 0.04 & Q. 025 & \\
\hline 6 & 0.02 & 0.04 & & \pm & 002 \\
\hline 7 & \pm & 0.15 & & & 0,02 \\
\hline
\end{tabular}

$\mathrm{mg} / \mathrm{kg}$ を静注した場合の膸液内移行成績は第 25 表们 示した.

30 分後では移行の 認められないもの 2 例，痕跡倳 2 例，他の 3 例は $0.015 \sim 0.032 \mathrm{mcg} / \mathrm{cc}$, 1 時間痕䟽様 1 例， 4 例は $0.03 \sim 0.15 \mathrm{mcg} / \mathrm{cc}$ ，2 時間痕跡様 1 例； 3 例以 $0.023 \sim 0.05 \mathrm{mcg} / \mathrm{cc}$ ，3 時間痕跡様 3 例，2 例は 0.025 $0.042 \mathrm{mcg} / \mathrm{cc}, 6$ 時間では移行の珰められない場合士例， 痕跡樣 2 例で他の 2 例は $0.02 \mathrm{mcg} / \mathrm{cc}$ である。

\section{III. 総括並びに考按}

クロラムフェニヨルを単独に静注した場合の 30 分德 に括ける移行度は $1.3 \sim 4.8 \mathrm{mcg} / \mathrm{cc}$ であるるのに刘して七 アルロニダーゼを併用した場合は $2.8 \sim 5.5 \mathrm{mcg} / \mathrm{cc}$ 就 トブロミンを併用した場合は $2.2 \sim 6.2 \mathrm{mcg} / \mathrm{cc},=ニ テ ッ$ 酸アミドを併用した場合は $2.4 \sim 5.5 \mathrm{mcg} / \mathrm{cc}, 1$ 、 1 \% ン併用の場合は 1.3 5.0 mcg/ccである・おなわちイ ダ ンンを除いては軽度の移行度の増加が諗められ 万.

1 時間後では単独使用では $1.2 \sim 5.5 \mathrm{mcg} / \mathrm{ccr}$ してヒアルロニダーゼ使用は $4.5 \sim 8.4 \mathrm{mcg} / \mathrm{cc}$;

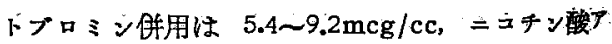
ミド併用は 4.8〜7.8 $\mathrm{mcg} / \mathrm{cc}, 1$ ミダリン併用忙 2.8

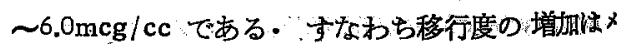

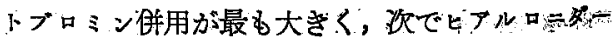
ぜ，ニンチン酸アミドでイミダリンでは極く軽度て 
क字.

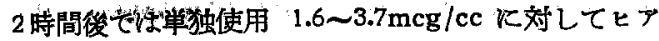
ルロニダーも゙併用は 3.3〜6.2mcg/cc，メトブロミン併用

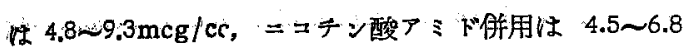
ticg/cć, オミダリン 2.5 5.6 mcg/cc である・すなわ タメトブロミンルよる影響が最む大きく，次でニュチン 醕アミド，ヒアルロ=ダーゼ，イミダリンの順である。 - 3 時間後では単独使用 $1.6 \sim 3.2 \mathrm{mcg} / \mathrm{cc}$ に対してヒア

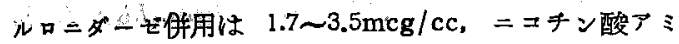
併用は $2.5 \sim 5.8 \mathrm{mcg} / \mathrm{cc}$ ，メトプロミン併用は $1.8 \sim$ $5.3 \mathrm{mcg} / \mathrm{cc}$, イミダリン併用は $1.8 \sim 4.0 \mathrm{mcg} / \mathrm{cc}$ てある。 この゙場合は割合に影響が少く，ことにヒアルロニがー ゼ, オミダンンは移行度に及ぼす影響が少い.

6 時蔺後では単独使用 $1.2 \sim 2.2 \mathrm{mcg} / \mathrm{cc}$ に対してヒア ルロニダーゼ併用は $1.8 \sim 2.6 \mathrm{mcg} / \mathrm{cc}$ メトブロミン 1.6

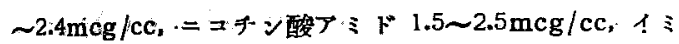
ダリッ 1.6〜2.8meg/ccで，ほとんど影響が認められな l..

すなわちクロラムフンニュルの䯣液内移行に対する影 響は 1〜2 時間炕軽度に認められ，メトブロミン併用の 場合踥最る大きく，次でヒアルロニダーゼとニュチン酸 アミドであり，イミダリンではほとんど影響が諗められ ない.

つぎに軻夜内移行度の悪いェリスロマイシンに対する 影響们ついてみると，単独使用 30 分後では 0 × 0.028 meglèc K嚆してとアルロニダーゼ併用は浪跡様〜0.05 $\mathrm{mcg} / \mathrm{cc}, \times ト$ マブミン痕跡様〜 $0.045 \mathrm{mcg} / \mathrm{cc},=$ ニン

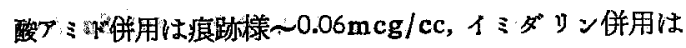
0 0 032mcg/cc で， 1ミダリンを除いては移行度の堌

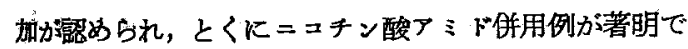
कる.

$\therefore$ 時間後では単独使用 $0 \sim 0.08 \mathrm{mcg} / \mathrm{ccc}$ に対してヒア

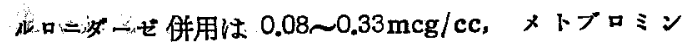
研用は 0,055 0.4 mcg/cc, ニコテン酸アミド併用は

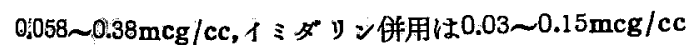
心，全例之，著明な移行度の増加が認められメトブロ 、ンルよを影響が最も大きく，㳄がニュチン酸アミドと ヒアルロニダーも゙で，イミダリンによる影響は軽度であ る.

2 2 時間後では峃独使用 $0 \sim 0.042 \mathrm{mcg} / \mathrm{cc}$ に嚆して, ヒ

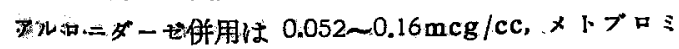

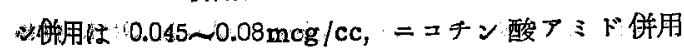

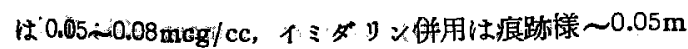

$\mathbf{c g} / \mathbf{c c}$ でこの場命もイミダリシを除けば相当の移行度 の増加が認められる。

3 時間後では単独使用 0 0 038 $\mathrm{mcg} / \mathrm{cc}$ に対してヒア ルロニダーゼ併用は 0.025 0.08 mcg/cc，メトブロミン 併用は $0.02 \sim 0.075 \mathrm{mcg} / \mathrm{cc}$ ，ニロチン酸アミド併用は $0.03 \sim 0.14 \mathrm{mcg} / \mathrm{cc}$, イミダリンでは痕跡様〜 $0.042 \mathrm{mcg}$ / $\mathrm{cc}$ で，この場合にもな怙相当な移行度の増加が認めら れる。

6 時間後では単独使用 $0 \sim 0.023 \mathrm{mcg} / \mathrm{cc}$ に対して, ヒ

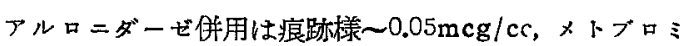

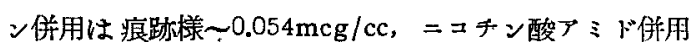
は痕跡様 $~ 0.045 \mathrm{mcg} / \mathrm{cc}, 1 ミ$ ダリン併用は 0 0.02 $\mathrm{m} \approx \mathrm{g} / \mathrm{cc}$ で，この場合儿は軽度の移行度の堌加が認め られる。

すなわちエリスロマイシンの䯠液内移行に及ぼす影響 は3 時間までは著明侄められ，6時間後でる軽度であ るが影響忹認められる・たよ゙しイミダリンによる影響は 認められない。

補助薬による主風の䯣液内移行堌加の機転について， 前田，梁頼はあるるのは眇血管にたいして選択的にこれ を桩大し，またあるものは間接にこれに関与し，またつ ルカロイドのごとき複雑な作用を有するるのでは各種の 作用によつて䯣膜の血管系統に異常をきたし，血流の障

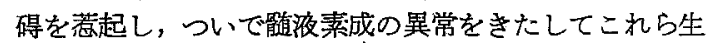
理的状態の平衡失調をきたし，こつに主成の透過を容易 ならしむるものであるらと述べている・しかして金野教

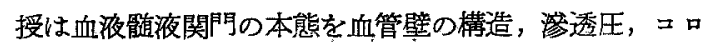
イド㴓圧，膜平衡扣よび神経支配によるモザイク現象 であろうと発表している。

メトブロミン，ニコチン酸アミドは自律神経作用す る薬物で，その神経節において節前線維と節後線維を遮 断するから䯣膜に分布している血管の運動神経の失調を きたし，またヒアルロニダーぜは拡散区子として晴膜な らびに血管壁に直接作用して透過性の変化をきたするの と侾えられるが，単独に使用しても，比較的よく移行す るクロラムフェニコルに対してはこれらの補助薬の作用 は轾度でしかも増吅の时間も短く単独使用では移行し難 いェリスロマイシン，ペニシリンに対しては補助䔉併用 の齐果が大で，增加の時間も長いことは血管壁の状態の みならず，真下のスルフアミン剂関する実験成績から みても抗生物質の血夜内分布にも左右されるものと考克 られる・ 
IV. . 結 論

1. ヒアルロニダーゼ, メトブロミン括よびニュチン 酸アミドは抗生物犋の髄液内移行度を堌加するが：1ミ ダリンは髄液内移行に対する影響は少い.

2.クロラムフェニコルのよらに比較的よく䯠液内に 移行するものに刘しては補助薬の影響は軽度で， $1 〜 2$ 時間に僅かに移行度の堌加が誌められる。

3. エリスロマイシンのように䯣液内移行の亜いもの に対しては3 時間までは著明な移行の増加が認められ， 6 時間後でる軽度ではあるが影響が認められる。

\section{文献}

1) Abraham Levinso: Am. J. of Diseases of children 77 (June). 2) Allot: Lancet 235; II, 13, 1939. 3) Appelbaum, E. and Nelson, J.: J.A.M. A. 128; (Jul) 1945. 4) Baggenstoss, A,M: Am. Rev. Tuberc. 55, 1947. 5) Barker, L.: Am. J. Med. Sci. 206:701, 1943. 6) Boger, W.P. et $a^{7}$.: Proc. Soc. Exp. Biol. \& Med. 68: 101, 1948. 7) Boger, W.P. et al.: Am. J. Med. Sci. 217: 593, 1949. 8) Cairns, H. et al.: Lancet 2 (Avg) 1946.

9) Chinn \&. Bellows: J. Lab. \& Clin. Med. XXV; 735, 1940. 10) Cooke, J. \& D. Go'dring: J. A.M. A. 127 ; 80, 1945. 11) Cutting \& Sultan: Am. J. Int. Med. 16:708, 1942. 12) Cutting \& Sultan: Am. J. Med. Sci. 5 : 1943. 13) Dinglet al.: J.A. M.A. 116, 1941. 14) de Pay: Klin Wschr. 34 : 1 193, 1938. 15) Dolphin, A.: Lancet 247:393, 1944. 16) Dowling. H. F. et al: 'J.A.M.A. 139 : 755, 1945. 17) Dowling, Lepper, Caldwell, Whelton and Brickhouse: J. Clin. Jinves. 28 (5): 983, 1949. 18) Dumoff-Stamley, E.: J. Clin. Invest. 25: 87, 1:46. 19) Dwight Davis, C.W. Anderson \& A.E. Landy: Annals of Western Medicine \& Surgery. 216: 1948. 20) Eldahe, A.: Lanect I: 712, 1938. 21) Erickson, T.C. et al.: J.A.M.A. 132 (10): 561, 1946. 22) Evans, A.L.: J.A.M.A. 124:641, 1944. 23) Farrington, R.F., Smith, M.M., Bunn, P.A and Mc Dermott, W.: J.A.M.A. 134 (June) 1957. 24) F.G. Hobson \& D.H. Mac Quaide: Lancet II : 1213, 1933. 25) Florey, $M$. \& H. Florey; Lancet 244 : 387, 1943. 26) Furstenbeg, A.C.: Ann. Otol. Rhin. \& Laryng. 58: 5〜 17, (March) 1949. 27) Herrell, W.E.: J.A.M.A. $124: 622,1944$. 28) He- witt: New. Eng. J. Med. 242 (4): 1950, 29) who. bby, Reed, Rinne, Powers and D'ambrosias Prac. Soc. Exp. Biol, \& Med. 73 (3): 511,1950 . 30) Horwilz \&. Perron: Areh. Mt. Med. 74: 365,1944. 31) Janowitz, H.D. et al.: T. Lab. \& Clin. Med 33: 933, 1948. 32) Jaueck u. Gueffroy: Klin. Ws chr. $44: 1544,1937 . \quad 33)$ Johuson, H. \&. A. Wal ker: J.A.M.A. $127: 217,1945$. 34) Johnsom H, C. Walker, A.E. Case, T.J. and Kollros, J.K. Arch, Neurol. and Psychiat. 56 (Avg.) 1946. 35) K.M. S. Ainly Walker \& F.D. Basanquet: T.J.M,A.28 4, 1952. 36) Krebs \& Speakman: Brit. Med, $\mathrm{T}_{\text {, }}$ Jan : 12, 1946. 37) Marschall, Enerson \& Cutting: T.A.M.A. 108: 953, 1937. 38) Mc Dermoth.W. et al: Am. J. Syph. Gonor. \& Ven. Dis. 29: 403, 1945. 39) Minota: J. Antibiotics. 3 (1):1 1, 1949. 40) Murphy et al.: Am. J. Med. Scil 5: 717. 1943. 41) Price, A.H. \&. J.H. Hodges:" New york State J: Med. 44 : 2012, 1944. 42) Rammelkampf, c. \&. c. Keefer: J. Clin. Invest. 22: 425; 1943. 43) Reienhdal, Harrison, Schwartz \& Alcert: Am. J. Med. Sci. 201 : 107, 1941. 44) Rending, J. \&. Crammer: J.A.M.A. $134:$ 16, 1947. . 45) Rosenberg, D.H. and Sylvister, J.c: Sciense 100: 132 Aug 1944. 46) Ross \&. Burke J.A.M. 133, 1947. 47) Rundberg, R. \&. Sjoberg, A.J. Laryng. \& Otol. 63: 446 Aug 1949. 48) Russelh \&. Falconer: Laucet 239 : 100, 1940. 49) Sanders, Rumball, Solomon, Soret and Ricci: T. Clin. Inves. 285: 1006, 1949. 50) Schwemlein, G. et al.: T.A. M.A. 130:340, 1946. 51) Siegal: S.T.A.M:A, 129oct : 574, 1945. 52) Smith, H.E. Duthie \&. H. Cairns: Lancet 251: 185, 19.46. 53) Speicer, $S$. \& D. Blitz: T. Lab. Clin. Med. 33: 417, 1948; 54) Strass et al: Ann. Mt. Med. 14 : 1390, 1941. 55) Sweet, L. K,. Dumott-Stanly, E., Dowlitg H,E and Lepper, M.M.: J.A.M.A. 127 Feb 1945. 56) T. Broman: The permeability of the Cerebros pinal Vessels in normal and pathological condition 1949. 57) Walker, A: Arch. Neur. Psych. 58: 39, 1947. 58) Walker, A. \& H. Johnsons Ann. Surg 122: $1125,1945 . \quad 59)$ Weber; Arch. Otolaryghg. $38: 161,1950.60)$ Wesner: Lancet $236 ; \mathbf{I}, 18$, 
1938. 61) Wrlker \&. F.D. Easanquet: Lancet 6705 : 433, March I. 1952. 62) Warnner, Knight and Mc Dermott: Proc. Soc. Exp. Biol. \& Med. $742: 261,1950$. 63) Wyke, B: Surg. Gyn. Abst. 85: 340, 1947. 64) Wood. W. S. and Kipnis G.P.: Antibiotics Aunual 1953 54, pp. 98. 65) 飯塚: 日新医学，38〜6, b. 353, (炤 26). 66) 明石：J. Antibiotics III, 14,956, 1950.67) 侍尔：京都医 学蓶誌, $38,5,362$, (昭 16). 68) 责木：京都医学雑

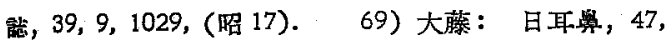

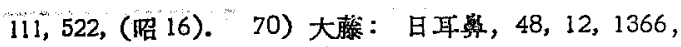
(嘌 17). 71) 藤井：日本臨床，8，5，(昭 25). 72) 藤田：同仁会医学雑誌，18,10（炤 19). 73) 深瀨：

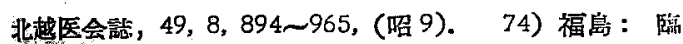
偻成科小完科，4，9（昭 24):75）林：北越医会誌， $58,2,134$ （昭 18). 76) 获間：新渴医会誌，64，7， 443，(炤 25).77) 平田：実験医報，27,6,816, (嚁 16). 78) 日下：治将学雑誌，12，1，46，(昭 17). 79) 本多: 臨外科，3，25（炤 23). 80) 今并：耳咽 科, $13,11,767$ ，(昭 15). 81) 今并：日整外会誌， 11, 290，(炤 11). 82) 礒田：京都府立医大誌，43， 4, 169, (昭 23). 83) 石山：最新医学, 8, 10, (炤 28). 84）鍵和田・䁷永：兒科雑誌，54，3，124，(炤 25).

85）䣄和田：日兒科会誌，58，9，823（昭 29). 86)

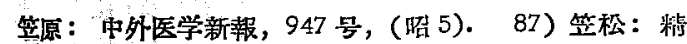

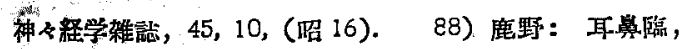
44，11，(炤 26). 89）加藤：大阪医会誌，39，10,

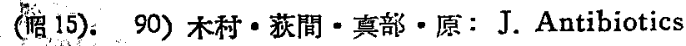
III, 1, 53, 1949. 91) 小格：京都府立大誌，19，4, 1676, (㽞 13). 92) 小林：日本細菌学雑誌，5，4,

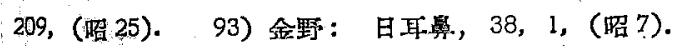

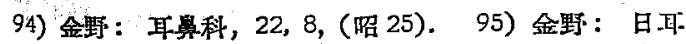

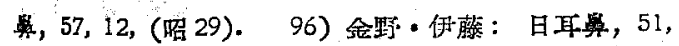

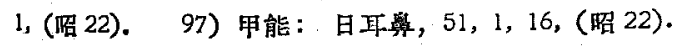
98) 久保：日本医師会雑誌，28，2，41，(昭 27). 99) 黑川：日耳鼻，49,9，813（昭 18).100) 真鍋：日

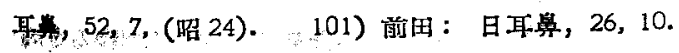
102)索下：回新医学，36,10,456, (嚾 24). 103) 淞

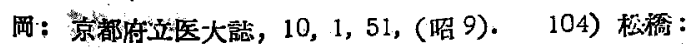

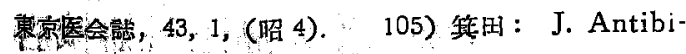
otics III, 1, 1, 1949. 106) 箕田：J. Antibiotics JI $, 3,153,1250.107)$ 三林：新潟医会誌。108）

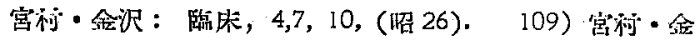
沢：J. Antibiotics IV, Suppl. A. 40 (March), 195l. 110) 宦特 - 食沢：J. Antibiotics IV, 4, 228 (May) 1951. 111) 宮村 - 全沢：J. Antibiotics IV, 8, 470 (Nov) 1591，112）宮田：日本隐床，8，4，(詔 21).

113) 森：福䣲医大誌，31，4，467（昭 13). 114）永 斗：日完科会誌，55，6（炤 26).115) 永谷：罗科

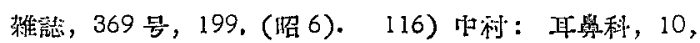
6, 575, (佋 12). 117) 柇：京都府主医大誌，43， 4, (炤 23). 118) 蛙利：日耳悬，53，4（招 25）。

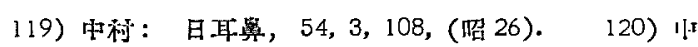
川・㴼山・班江：J. Antibiotics. III, 7, 422, 1950. 121）成智・山田：医朱內科小兒科，3，22（昭 23). 122）老川：日本医学及び集康保険，3323 告，433，(炤 18). 123) 閏猗：棏神之経学雑誌，54，2，161，(昭 27). 124) 小山：京都医学倠誌，25, 10, 836, (哆3). 125) 崔：治源医学, 499 号, 16, (昭 16). 126) 斎藤： 日內分泌会誌，6，183，(昭 5). 127）三辺：日耳舆， 53，4，(昭 25). 128) 三边・岩崎・上木・山崎；日耳: 需，53，9，391，(昭 25). 129）三辺：日耳學，52，1，

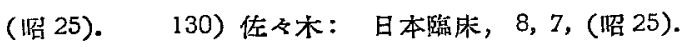
131）佐子末：日兒科会誌，55，8，387，(昭 26)。132) 径藤・種子：治漳医学，506 号，5, (昭 17). 133) 清 水：大阪医会誌，27，11，(炤 3). 134) 白狗：最新 医学，81，1，25（炤 28)，135）相馬：臨床日本医学， 32, (昭9). 136) 高原：耳斯阽，37, 16,7, (炤 17).

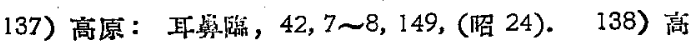
原：日耳舆，51，8（炤 23). 139）高原：日耳器，

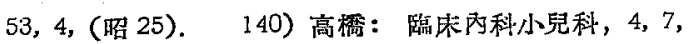
(昭 24). 141) 竹崎：日本䧊㶧, 83，(炤 25). 142)

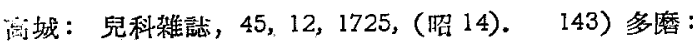
日新治璙，385 号，1005，(炤 16). 144）垂水：大阪 医会誌，37，2，271，(炤 13)。145）富川-火関：兒 科傍琦，14，2，82（昭 26），146）富島：大阪医会誌，

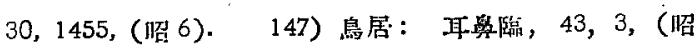

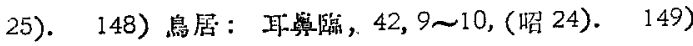

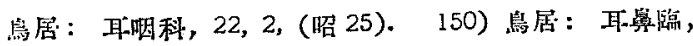

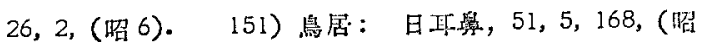
23). 152) 鳥居：医学，4，3，113，(昭 23). 153) 鳥居：新渴医会誌，61，4，294。(炤 22). 154) 点虞：

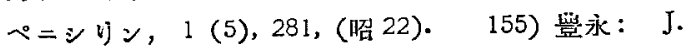
Antibiotics V, 7, 370, 1952. 156) 豐永：日兒科令 


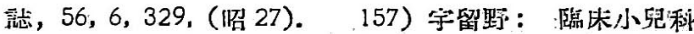

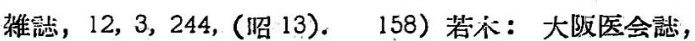
26, 8, (沼 2). 159) 若禾: 大阪医会誌，28，11（炤 4). 160) 若木木：大阪医会誌，29,2〜5, (炤 5). 191) 源辺：医寒公諭，1436 号, 382, (昭 15). 162) 遊上: J. Antibiotics. V, 11, 1952. 163) 屍山能：大阪医 会誌, 29, 12, (照 5).

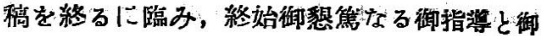
校閴を賜わつた恩師金野㛜教授に゙深萝の誐意 荠します。

（原稿到着＝炤科 34.5 .18 日一急载）

\section{プロス新型耳鼻科ユニット}

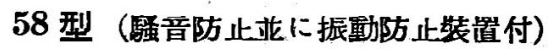

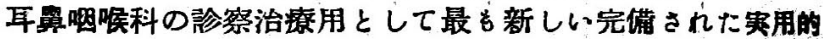
な裝惪であります。全体は全鋼跌製で移動車が取り付けてす ク，その上焼付メラiン塗裝を施し，器峨盤スブレイ台その 他の部分にばステンレス磨板，デザインが佽美で診察室に最 ஆふさわしいすのであります。

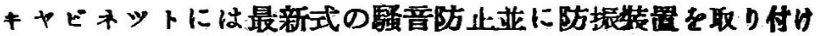

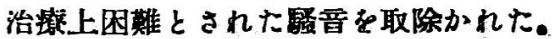
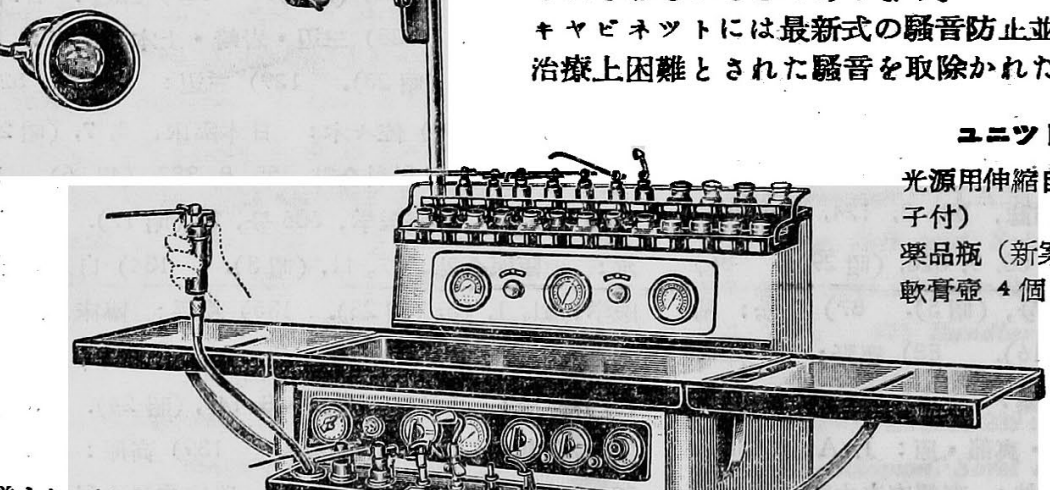

詳しいハンフ レットは申迈 饮第画送致し ます)

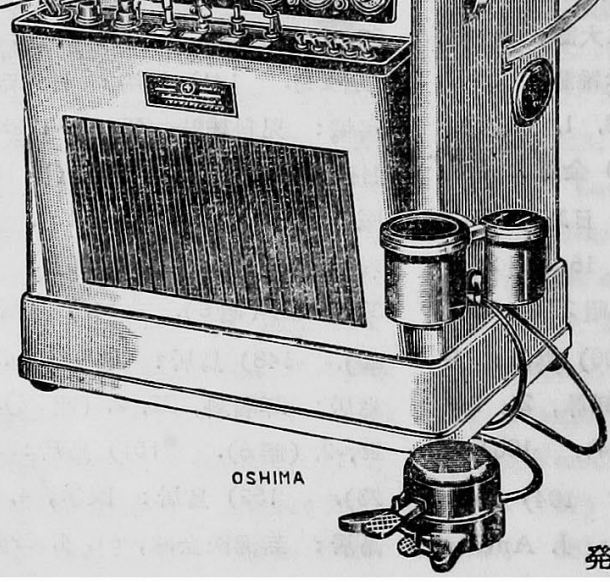

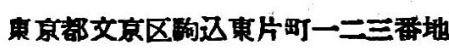

\section{ユニソトの部品並に附属品}

鼓膜按摩器 (小型モーター) ネフライザー（代力調節器付)）。

王縮タンク代力メータ一付（吸引使 用中にてるスプレイ使用可能，電動 幾 2 台の能率むる)

電期 暁灼

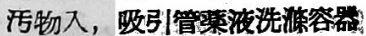

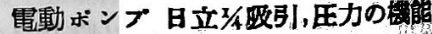
を有す

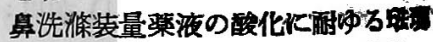

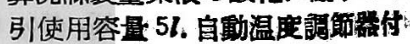

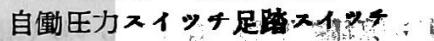

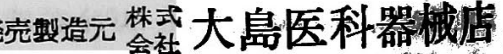
wost 